Icaro Demarchi Araujo Leite

\title{
Tema: “O Direito Internacional do Meio Ambiente e a Aplicação de seus Princípios e de suas Normas pela Empresa"
}

\author{
Dissertação de Mestrado
}

Orientadora: Professora Doutora Elizabeth de Almeida Meirelles Área de Concentração: Departamento de Direito Internacional DIN

Universidade de São Paulo

Faculdade de Direito

São Paulo

2011 
Icaro Demarchi Araujo Leite

\section{O Direito Internacional do Meio Ambiente e a Aplicação de seus Princípios e de suas Normas pela Empresa}

Dissertação apresentada à

Faculdade de Direito da Universidade de São Paulo para obtenção do título de Mestre em Direito.

Área de Concentração: Direito Internacional - DIN

Orientadora: Professora Doutora Elizabeth de Almeida Meirelles.

São Paulo 
Nome: LEITE, Icaro Demarchi Araujo

Título: O Direito Internacional do Meio Ambiente e a Aplicação de seus Princípios e de suas Normas pela Empresa
Dissertação apresentada à Faculdade de Direito da Universidade de São Paulo para obtenção do título de Mestre em Direito.

Aprovado em:

Banca Examinadora:

Prof. Dr.

Julgamento:

Prof. Dr.

Julgamento:

Prof. Dr.

Julgamento:
Instituição:

Assinatura:

Instituição:

Assinatura:

Instituição:

Assinatura: 


\title{
DEDICATÓRIA:
}

\begin{abstract}
A Deus,
À minha família (Francisco, Teresa, Teda e Degas) pelo amor incondicional,

À Barbara Scavone Bellem de Lima pelo amor, paz e alegria que me transmite em cada momento do meu dia, companheira de vida,
\end{abstract}

Aos grandes amigos que me acompanharam todos esses anos apoiando e dando-me forças para conseguir terminar esse trabalho,

A Drummond Saraiva Leite, que tal como Enoch, Deus preferiu tê-lo mais próximo e nos privou de sua presença. 


\section{AGRADECIMENTOS:}

Em primeiro lugar agradeço a minha orientadora, Professora Elizabeth de Almeida Meirelles, pessoa jovial e sorridente que sempre me acolheu com carinho, mesmo quando ficamos distantes em alguns períodos do curso. Sua capacidade de me tranqüilizar e trazer um sorriso amigo sempre foi muito importante, ajudando-me muito na consecução final que é a defesa dessa dissertação.

Agradeço a meus Professores da Faculdade de Direito da Universidade de São Paulo, por todos esses anos de estudo e dedicação, que me brindaram com muitas palavras de carinho e uma enxurrada de conhecimento. Em especial, aos Professores e funcionários (Edna e Aiko) do Departamento de Direito Internacional, com quem tive maior contato, pois mesmo nas críticas mais elevadas souberam ensinar o caminho para o meu melhor desenvolvimento. Agradeço em especial ao Reitor da Universidade de São Paulo, Professor Doutor João Grandino Rodas, com quem tive a honra e privilégio de trabalhar. Sua disposição em ajudar e a forma como me ensinou a arte da convergência são os grandes ensinamentos que levarei por toda vida.

Aproveito para reiterar meus agradecimentos familiares, em especial à minha mãe, Maria Teresa Demarchi Araujo Leite, que soube suportar o mau humor das noites mal dormidas com muito carinho e dedicação, inclusive fazendo companhia nas madrugadas adentro. Agradeço a minha namorada Barbara Scavone Bellem de Lima, companheira de todas as horas, que soube suportar dias solitários enquanto escrevia essa dissertação, sua paciência e amor incondicional foram essenciais para que eu pudesse ter a calma necessária até o término da feitura do trabalho.

Agradeço aos meus queridos amigos, especialmente os Doutores da Turma 179, que me acolheram muito bem em seu seio e fizeram prorrogar os meus melhores sentimentos dos tempos de Faculdade. Prolongo o agradecimento aos amigos para algumas pessoas especiais, Dr. Edison Magnani e Dr. Carlos Alberto Siciliano, que durante o período em que trabalhamos juntos ensinaram-me o que é uma atuação séria no campo empresarial, com respeito ao próximo, sempre primando pela excelência e estreito desenvolvimento pessoal e profissional.

Por fim, agradeço a todos aqueles que de uma forma ou de outra contribuíram para a conclusão desse trabalho. 


\section{EPÍGRAFE:}

"Nenhum homem pode atravessar o mesmo rio duas vezes, porque [já] nem o homem nem o rio são os mesmos." - Heráclito 


\section{RESUMO}

Leite, I. D. A. O Direito Internacional do Meio Ambiente e a aplicação de seus princípios e de suas normas pela empresa. 2011. 141 f. Dissertação (Mestrado) Faculdade de Direito, Universidade de São Paulo, São Paulo, 2011.

A presente dissertação de Mestrado é um estudo sobre a aplicação de normas e princípios do Direito Internacional do Meio Ambiente pela empresa. O estudo inicia-se com o exame da matéria Direito Internacional do Meio Ambiente, perpassa um breve histórico do seu surgimento, seguido da conceituação, a indicação de suas principais fontes e princípios. Após, é analisada a segunda parte do fulcro dessa dissertação, qual seja, o nascimento da empresa moderna. Para tal, foi realizado levantamento histórico sobre o comércio, consequentemente, sobre o Direito Comercial, perpassando pelo conceito econômico e jurídico de comércio, analisando a dicotomia entre Direito Econômico e Direito Comercial. Por fim, foi realizada pesquisa mais aprofundada sobre o surgimento do termo empresa com a delimitação de sua natureza jurídica e conceituação no Direito brasileiro. Em item apartado, foi analisada a conceituação de empresa transnacional, instituição esta de grande relevância para o desenvolvimento do presente estudo. No terceiro capítulo foram analisadas as externalidades positivas e negativas da economia e como essas externalidades se tornaram, por meio do Direito, um custo para a atividade empresarial, especialmente no que concerne ao meio ambiente. Em seguida, realizou-se um levantamento mais detalhado do histórico do Direito Internacional do Meio Ambiente, a partir da Conferência das Nações Unidas sobre o Meio Ambiente Humano de 1972 em Estocolmo. Nesse ponto da dissertação é mais bem visualizado como se deu o surgimento consensual do princípio do desenvolvimento sustentável, sob uma perspectiva direcionada para o alcance desse ponto importante do meio ambiente para o universo empresarial. Por fim, tem-se a análise da aplicação dos princípios e normas do Direito Internacional do Meio Ambiente por parte do universo empresarial, indicando quais são os tipos de recepções possíveis, demonstrando o atual desenrolar da agenda global ambiental, bem como os novos cenários que se descortinam para o desenvolvimento sustentável do Meio Ambiente pelo Direito Internacional.

Palavras-chave: Direito Internacional do Meio Ambiente - Empresa - Direito Comercial - Direito Empresarial - Aplicação - Normas - Princípios - Desenvolvimento Sustentável. 


\begin{abstract}
Leite, I. D. A. The International Environmental Law and the application of its principles and rules by the company. 2011. 141 s. Dissertation (Master) - Faculdade de Direito, Universidade de São Paulo, São Paulo, 2011.

The present dissertation is a study on the application of rules and principles of International Environmental Law by the company. Firstly, it hods an examination of the International Environmental Law as a subject, and passes through a brief history of its emergence, followed by the conceptualization, and the indication of its main sources and principles. Secondly, the core of this dissertation, called "the birth of the modern enterprise" is analyzed through gathering historical data on trade thus on Trade Law, going throughout the legal and economic concept of trade, analyzing the dichotomy between Economic Law and Commercial Law. Afterwards, is carried out a research on the emergence of the term enterprise with the delimitation of its legal nature and conceptualization in Brazilian law. In item apart, is analyzed the concept of transnational company, this institution of great importance for the development of this study. The third chapter is about the positive and negative externalities of the economy and how these externalities became, through the law, a cost for corporate activity, especially in relation to the environment. Subsequently, is performed a more detailed survey of the history of International Environmental Law from the United Nations Conference on the Human Environment in Stockholm in 1972. At this point of the work is easy to notice how the consensus principle of sustainable development has appeared as a perspective directed towards the achievement of this important aspect of the environment for the business world. Finally, is analyzed the application of the principles and norms of International Environmental Law by the business community, indicating what are the possible receptions, showing the current progress of the global environmental agenda, as well as the new scenarios that are been revealed in regard to the environment's sustainable development by the International Law.
\end{abstract}

Keywords: International Environmental Law - Business - Commercial Law - Business Law - Application - Rules - Principles - Sustainable Development. 


\section{LISTA DE ABREVIATURAS E SIGLAS}

ABIQUIM - Associação Brasileira da Indústria Química

ABRAPP - Associação Brasileira das Entidades Fechadas de Previdência Complementar AIEA - Agência Internacional de Energia Atômica

ANBIMA - Associação Brasileira das Entidades dos Mercados Financeiros e de Capitais

APIMEC - Associação dos Analistas e Profissionais de Investimento do Mercado de Capitais

CDP - Carbon Disclosure Project

CEBDS - Conselho Empresarial Brasileiro para o Desenvolvimento Sustentável

CFCs - Clorofluorcarbonetos

CNUMAD/UNCED (sigla em inglês) - Conferência das Nações Unidas para o Meio

Ambiente e Desenvolvimento

COPs - Conferences of the Parties

CQNUMC - Convenção Quadro das Nações Unidas sobre a Mudança do Clima

DDT - Dicloro-Difenil-Tricloroetano

ECOSOC - Economic and Social Council

EUA - Estados Unidos da América

FAO (sigla em inglês) - Organização das Nações Unidas para Agricultura e Alimentação

FMI - Fundo Monetário Internacional

FROG - First Raise Our Growth

GE - General Eletric

GEE - Gases do Efeito Estufa

GEF (sigla em inglês) - Fundo Global para o Meio Ambiente

GEO - Global Environmental Organization

IBGC - Instituto Brasileiro de Governança Corporativa

ICCA (sigla em inglês) - Conselho Internacional de Associações da Indústria Química

ICSU (sigla em inglês) - Conselho Internacional para a Ciência

IFC - International Finance Corporation

IPCC (sigla em inglês) - Painel Intergovernamental sobre Mudanças Climáticas

ISE - Índice de Sustentabilidade Empresarial

IUCN (sigla em inglês) - União Mundial pela Conservação da Natureza 
MDL - Mecanismo de Desenvolvimento Limpo

MIT (sigla em inglês) - Instituto de Tecnologia de Massachusetts

MW - Megawatts

OCDE - Organização para a Cooperação e Desenvolvimento Econômico

OIT - Organização Internacional do Trabalho

OMC - Organização Mundial do Comércio

OMI/IMO (sigla em inglês) - Organização Marítima Internacional

OMM - Organização Meteorológica Mundial

OMS - Organização Mundial de Saúde

ONGs - Organizações Não-Governamentais

ONU/UN (sigla em inglês) - Organização das Nações Unidas

PNUD - Programa das Nações Unidas para o Desenvolvimento

PNUMA/UNEP (sigla em inglês) /PNUE (sigla em francês) - Programa das Nações

Unidas sobre o Meio Ambiente

SRI - Investimentos Socialmente Responsáveis

TNCs - Transnational Corporations

UE - União Européia

UNESCO - United Nations Educational, Scientific and Cultural Organization

UNIDO (sigla em inglês) - Organização das Nações Unidas para o Desenvolvimento Industrial

WBCSD (sigla em inglês) - Conselho Empresarial Mundial para o Desenvolvimento Sustentável

WRI (sigla em inglês) - Instituto Mundial de Recursos

WWF - World Wild Foundation 


\section{SUMÁRIO}

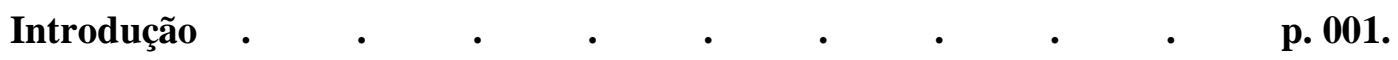

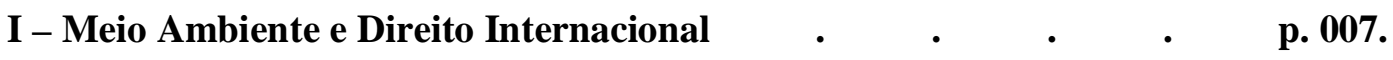

1.1) Breve histórico do tratamento dado ao Meio Ambiente _ p. 007.

1.2) O surgimento do Direito Interno e Internacional do Meio Ambiente

p. 008.

1.3) O conceito de Direito Internacional do Meio Ambiente _ p. 013.

1.4) As fontes do Direito Internacional do Meio Ambiente . p. 014.

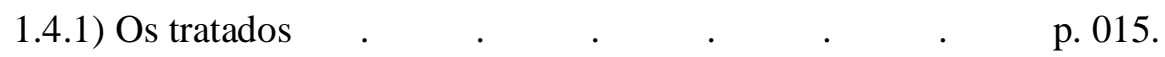

1.4.2) O costume como fonte do Direito Internacional do Meio Ambiente

1.4.3) Os princípios gerais do Direito _ . . . $\quad$ p. 017.

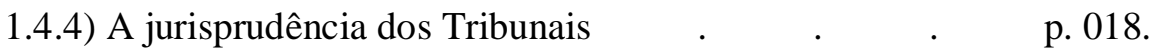

1.4.5) A doutrina dos autores mais qualificados . $\quad$. p 020.

1.4.6) As resoluções sobre Meio Ambiente das Organizações Internacionais

1.4.7) As Organizações Não-Governamentais (ONGs) p. 021.

1.5) Princípios do Direito Internacional do Meio Ambiente. p. 022.

1.5.1) O princípio da Cooperação Internacional e a Responsabilidade

Comum, mas Diferenciada . . . . . . . p. 024.

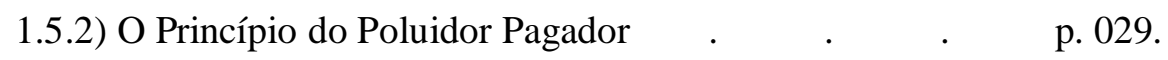

1.5.3) O Princípio da Prevenção e da Precaução • • p. 031.

1.5.4) O Princípio do Desenvolvimento Sustentável. p. 032.

II - Direito Comercial, Empresas e Internacionalidade . $\quad$ • $\quad$ • p. 034.

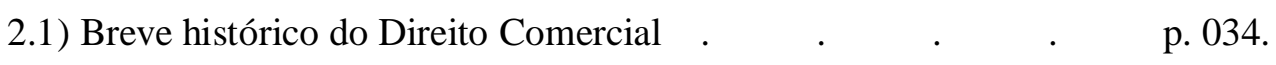

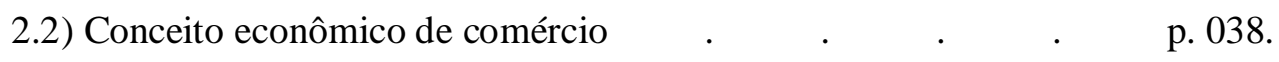

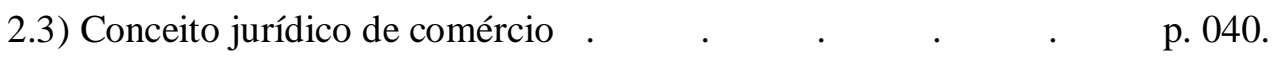

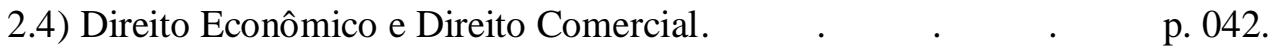

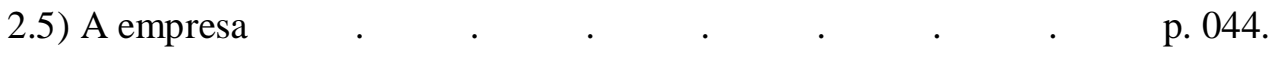

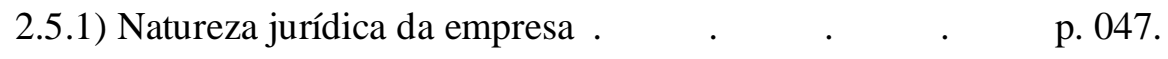

2.5.2) Conceito de empresa no Direito brasileiro _ . . p. 048 . 


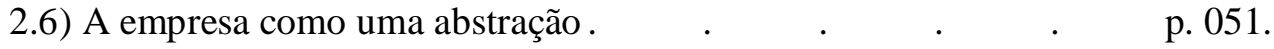

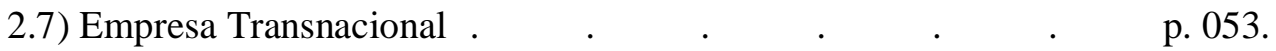

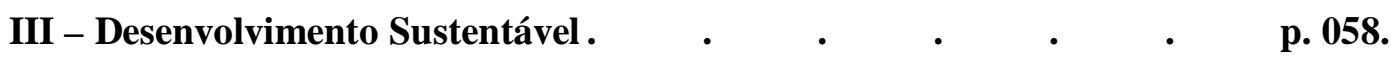

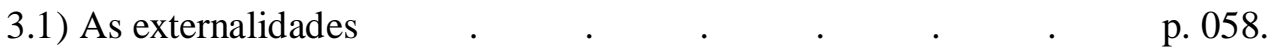

3.2) O Direito como custo para a atividade empresarial _ . . p p. 062.

3.3) O Direito Internacional do Meio Ambiente a partir de Estocolmo p. 065.

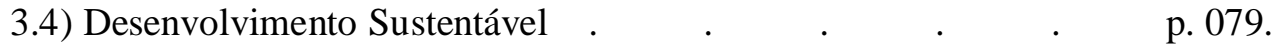

IV - A Aplicação das Normas e Princípios do Direito Internacional do Meio

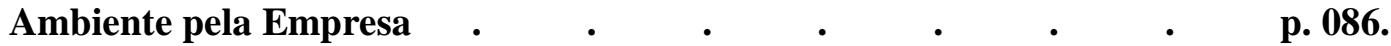

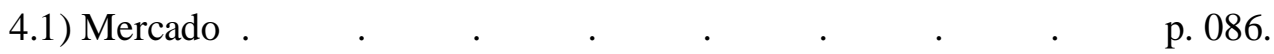

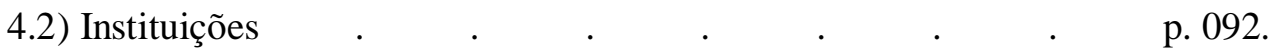

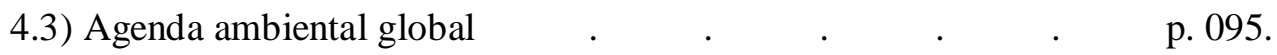

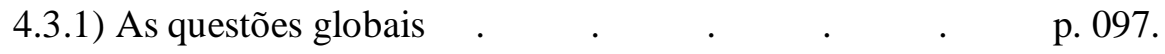

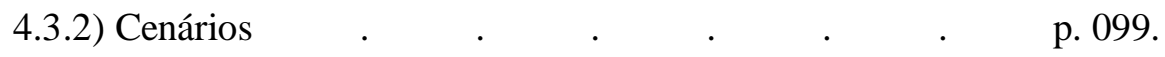

4.3.3) Ação doméstica e indiferença global . . p. 100.

4.3.4) Avaliações dos anos 1960 e 1970 . . p. 102.

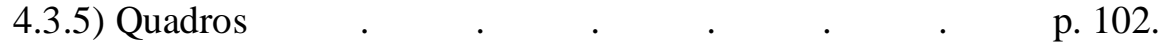

4.4) Aplicação de Princípios e Normas do Direito Internacional do Meio Ambiente

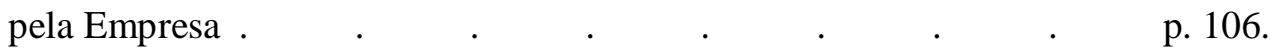

4.4.1) Princípios, normas e lucratividade econômica _ p. 108.

4.4.2) Desenvolvimento Sustentável e sua efetivação empresarial .

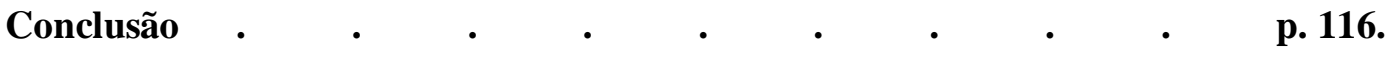

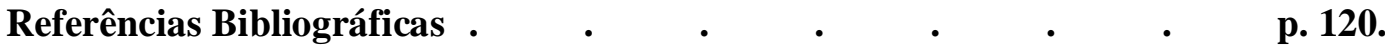




\section{INTRODUÇÃO}

Observa-se que, nas últimas décadas, a preocupação com o meio ambiente tem tomado lugar de destaque na mídia, na política e principalmente no Direito e na Economia. Dessa forma, muitos têm sido os questionamentos acerca das delimitações do que é plausível e viável na manutenção do bem-estar ambiental do planeta, em contraposição às benesses desenvolvimentistas do mundo globalizado. Nesse contexto é que nasce a idéia de desenvolvimento sustentável, termo muito utilizado atualmente e que agrada vários setores da sociedade, especialmente o político. Assim, a definição mais aceita de desenvolvimento sustentável é a do modelo capaz de suprir as demandas da geração atual, sem impedir a capacidade de atender as necessidades das gerações futuras.

Tal definição surgiu na Comissão Mundial sobre Meio Ambiente e Desenvolvimento (1987), criada pela Organização das Nações Unidas (ONU), em 1983, para reexaminar as questões problemáticas relativas ao meio ambiente e criar plataformas reais para abordá-las, bem como propor novos formatos de cooperação internacional para orientar as ações e políticas no sentido das mudanças necessárias, com o dever de possibilitar aos indivíduos, organizações não-governamentais, empresas, institutos e governos uma amplitude maior de compreensão de seus problemas relativos, buscando um aprimoramento para uma atuação mais firme nesse sentido.

Com uma plataforma montada em uma organização internacional de extrema importância como a ONU, inúmeros estudos foram surgindo com o passar dos anos, sendo que muitas metas e projetos foram criados com a intenção de estabelecer parâmetros que pudessem aliviar ou até mesmo solucionar os problemas existentes a respeito do meio ambiente. E foi com essa Comissão que surgiu a idéia de mesclar profunda e intensamente a relação entre meio ambiente e economia. No mesmo ano de 1987, a comissão recomendou a elaboração de uma declaração universal sobre a proteção ambiental e o desenvolvimento sustentável, o Relatório Brundtland", cujo título foi "Nosso Futuro Comum".

O discurso principal foi o de relacionar o desenvolvimento econômico à questão ambiental, criando não apenas um novo termo, mas uma nova forma de olhar o futuro. Para tal, os vários Estados deveriam adotar as seguintes premissas: limitar o crescimento 
populacional; garantir a alimentação no longo prazo; preservar a biodiversidade e os ecossistemas; baixar o consumo de energia e o desenvolvimento de tecnologias que utilizem o uso de fontes energéticas renováveis; aumentar a produção industrial nos países não-industrializados à base de tecnologias ecologicamente adaptadas; controlar a urbanização selvagem e a integração entre campo e cidades menores ${ }^{2}$.

Já na seara internacional, as metas propostas pelo Relatório apontam que as organizações devem indicar a estratégia de desenvolvimento sustentável; a comunidade internacional deve resguardar os ecossistemas supranacionais como a Antártica, os oceanos e o espaço; as guerras devem ser evitadas e a ONU deve implantar um programa de desenvolvimento sustentável. Em tais condições, deu-se início a um processo de internalização do meio ambiente ao Direito Econômico, situação esta que Fábio Nusdeo ${ }^{3}$ apresenta ao indicar que os sistemas econômicos e ambientais correspondem a duas esferas concêntricas. A maior, o sistema ambiental, conteria a menor, o sistema econômico ${ }^{4}$.

Tal relação era possível de se observar até o fim do século XIX, já que o sistema de produção era reduzido e não interferia de maneira exacerbada com o meio ambiente natural. No entanto, durante o século XX, com o aumento significativo da produção em escala mundial, a esfera econômica começou a se avantajar fora de qualquer proporção, a ponto de se aproximar perigosamente da esfera ambiental, em alguns períodos até mesmo chegando a tocá-la ou nela resvalar.

Dessa forma, algumas conseqüências surgiram, como a impossibilidade dos componentes do meio ambiente continuarem a ser tidos como bens livres, ou seja, o fim da distinção real entre ambas as esferas e entre os critérios prevalecentes em cada uma delas como conseqüência natural de sua fusão; bem como a entrada dos bens e processos de natureza ambiental no domínio do Direito, já que passaram a integrar o domínio da Economia $^{5}$. Assim, os bens ambientais passam a ser considerados como objetos do direito.

O meio ambiente, uma vez caracterizado como objeto econômico e jurídico, começa a passar por situações inóspitas, que nem sempre são correlatas com o fim a que se destinam. Um exemplo objetivo é a transmutação dos ecossistemas em mercadorias, ou seja, meios foram criados para que estes bens de direito pudessem ser comercializados em

\footnotetext{
${ }^{1}$ Nome advindo da ex-primeira-ministra da Noruega, Gro Harlem Brundtland, que presidiu a Comissão Mundial de Meio Ambiente e Desenvolvimento em 1987.

${ }^{2}$ Nosso Futuro Comum. Comissão sobre Meio Ambiente e Desenvolvimento. Rio de Janeiro. 1988.

${ }^{3}$ Nusdeo, F. Direito Econômico Ambiental, in Alves, A. C.; PhILIPPI JR., A. Curso interdisciplinar de direito ambiental. São Paulo: Manole, 2005, p. 717.

${ }^{4}$ NuSDEO, F. Desenvolvimento e Ecologia. São Paulo: Saraiva, 1975, p. 20-21.

${ }^{5}$ Nusdeo, F. Desenvolvimento e Ecologia. São Paulo: Saraiva, 1975, p. 23.
} 
benefício de um sistema que claramente opôs os países industrializados às nações subdesenvolvidas. Nesse sentido, mecanismos como a comercialização dos Créditos de Carbono ou Redução Certificada de Emissões, criados pelo Protocolo de Quioto, em dezembro de 1997, servem como forma de flexibilizar os problemas ligados ao desenvolvimento padrão, não sustentáveis.

A princípio, as inter-relações entre a regulação das atividades econômicas internacionais e as normas internacionais sobre proteção ao meio ambiente devem ser observadas levando-se em conta os três aspectos que formam a base dos fenômenos econômicos internacionais: na seara da movimentação internacional de créditos e financiamentos (Banco Mundial, bancos regionais, relações intergovernamentais bilaterais e entre empresas privadas), na área da regulamentação das finanças internacionais (Fundo Monetário Internacional - FMI) e no que concerne à regulamentação dos movimentos internacionais de bens materiais ou imateriais (Organização Mundial do Comércio OMC).

A partir dos estudos da Conferência de Estocolmo sobre o Meio Ambiente Humano, em 1972, em especial depois da adoção em 1988 do World Bank Environmental Guidelines, praticamente qualquer financiamento concedido internacionalmente, bem como as medidas internacionais exigidas ao amparo do FMI nos setores financeiro e monetário internacionais, obrigam a adequação de projetos governamentais - em especial os maiores - ou sob sua responsabilidade ou supervisão, às leis locais e/ou internacionais de proteção ao meio ambiente, devendo inclusive ser submetidos à análise prévia rígida de impacto ambiental.

Obviamente, tais exigências foram determinadas pelos governos de Estados fornecedores de recursos financeiros que, por pressões internas, já condicionavam suas atividades internacionais às avaliações de impactos ambientais nos grandes projetos financiados com recursos oficiais, da mesma forma como exigem para os projetos nacionais ${ }^{6}$.

Assim, pode-se observar que existem tentativas de resolver problemas ambientais por intermédio do mercado - por exemplo, nas rodadas comerciais multilaterais - que contribuem, concomitante, para a regulação econômica da ordem internacional. O que demonstra que as duas vertentes - de expansão do mercado mundial e de promoção de estratégias de desenvolvimento sustentável - seriam perfeitamente compatíveis.

6 Soares, G. F. S. Direito Internacional do Meio Ambiente: emergência, obrigações e responsabilidades. São Paulo: Atlas, 2001, p. 139. 
Alguns casos evidenciam fatores de interdependência econômica que se estabelecem em escala internacional: o meio ambiente torna-se setor importante do comércio internacional, não somente devido ao impacto que ele produz nas trocas, mas igualmente graças à utilização de práticas e políticas comerciais de caráter ecoprotecionista.

No momento em que as decisões políticas, econômicas e sociais são interdependentes, elas têm o potencial de constituir um sistema. O conjunto de obstáculos e oportunidades que se apresenta aos agentes internacionais pode formar um sistema de ação, ou seja, uma fonte de regulação. No plano internacional, as relações entre os agentes poderiam resumir-se a jogos baseados em necessidade de convergência, de interesses particulares e seus obstáculos. $\mathrm{O}$ encadeamento de decisões interdependentes em processo similar pode, sob condições precisas, produzir um equilíbrio que se estabeleceria com uma potencial regulação em escala global.

Quanto à regulação do meio ambiente pelo mercado, há que se lembrar que este passou a ser considerado como uma das áreas mais promissoras da economia mundial, sobretudo a partir dos anos 1970, tornando-se fator de interdependência econômica, como citado, e foi por meio da competitividade do mercado que se expressaram os diferentes meios de interdependência econômica internacional adstritas ao meio ambiente. É evidente que o meio ambiente formatou novos mercados: ecoturismo, reciclagem, ecoindústrias; toda uma nova linhagem de produtos e serviços surgiu em função de uma maior consciência e de novas formas de consumo relacionadas ao meio ambiente.

Porém, as possibilidades e os limites desse modo de operação do meio ambiente estão diretamente conectados com as características de toda economia de mercado. A regulação pelo mercado deverá basear-se em novos estilos de vida, procurando aumentar o "consumo verde". No que diz respeito às ecoindústrias, o meio ambiente é elemento revelador da lei dos rendimentos decrescentes, ou seja, todo esforço complementar de despoluição da água, do ar, entre outros, custará mais caro que a etapa precedente. O meio ambiente, assim, poderá produzir igualmente a conversão e a adaptação do conjunto do aparelho econômico.

Nesse sentido, é importante analisar as normas e princípios do Direito Internacional de forma mais aproximada, identificando situações em que a aplicação desses pontos seja de um interesse superior ao dos Estados. É preciso entender que o modelo ideal de trabalho e gestão em uma empresa deve ser pautado por princípios que abarquem suas externalidades negativas para a sociedade e saiba demonstrar que o melhor caminho é o de 
um desenvolvimento sustentado por modelos que sejam lucrativos e não causem danos ao meio ambiente, e no caso dos danos surgirem, que esses sejam mitigados da melhor forma possível.

Uma gestão empresarial competente e que tenha essas metas ambientais como proposta de futuro, certamente produzirá um efeito perpetuador dentro das empresas, alcançando o lucro no médio prazo e mantendo o fundamental que é a permanência da empresa no tempo. Um passo certo é imaginar que no que concerne às empresas, o Direito Internacional do Meio Ambiente tende a exercer uma proteção e uma forma de atuação muito peculiar que deve ser estudada sob a égide do Direito Internacional, da Economia e do Meio Ambiente, para que talvez um dia sua eficácia seja mais intrusiva tal como na proteção internacional dos Direitos Humanos.

Estes institutos econômicos e ambientais são interessantes de serem observados na prática, mas trazem a tona, no entanto, algumas questões interessantes: qual a aplicabilidade efetiva dos princípios do Direito Internacional do Meio Ambiente pelas Empresas? As normas de Direito Internacional do Meio Ambiente podem servir de parâmetros para as Empresas? As empresas transnacionais são o objetivo final da aplicação dos instrumentos internacionais do Direito Ambiental?

São com estes pontos controvertidos relacionando meio ambiente, economia e Direito Internacional que se chega ao tema a que se propõe esta dissertação de mestrado, qual seja o de uma análise da aplicação dos princípios e normas do Direito Internacional do Meio Ambiente pela Empresa e como essa efetivação deve servir de base para uma união cujos frutos sejam sociais, econômicos e ambientalmente responsáveis. É importante visualizar se essa aplicação é direta ou indireta; se ela deve se dar de baixo para cima, ou de cima para baixo; com a participação mais ativa em organismos internacionais ou utilizando-se da interessante experiência proclamada pelas Organizações NãoGovernamentais.

Tais pontos suscitam situações ainda pouco estudadas e que devem ser analisadas com maior aprofundamento para fortalecer as relações econômicas e jurídicas com o meio ambiente, como elas podem ser influenciadas e quais são os possíveis caminhos de sustentabilidade para as gerações futuras. A presente dissertação não tem o intuito de abarcar todas as possibilidades de introdução desses conceitos no arcabouço empresarial; da mesma forma, não é ingênua a ponto de imaginar que as empresas devem recepcionar as melhores práticas de proteção ambiental sem qualquer contrapartida. Todavia, o presente trabalho tem o intuito de ampliar a análise de situações que estão sendo debatidas por 
vários setores e que, de uma forma ou de outra, são absorvidas de maneira mais contundente do que por parte dos Estados, em tese os maiores interessados na proteção do meio ambiente.

Por fim, um relato pessoal é interessante de se apontar. Ao acompanhar as reuniões da COP-15 no final do ano de 2009, uma entrevista, de um representante de uma mineradora da América Latina, chamou a atenção. Dizia o representante que a política ambiental para o ano de 2010, naquela companhia, estava sobrestada em função das grandes reuniões que estavam acontecendo. Perguntado pelo repórter o porquê de tão inusitada espera na definição das políticas ambientais, o representante afirmou: "Nossa empresa já compreendeu que as decisões que foram tomadas aqui, devem orientar nossa política em todas as empresas do grupo, nos mais variados países. Adotar uma política que esteja de acordo com as diretrizes apontadas na COP-15 nos colocará em lugar de destaque socialmente, ambientalmente e economicamente".

Dessa forma, nas páginas seguintes estará uma pequena contribuição para que os esforços realizados por empresas, Estados e sociedade civil estejam de acordo com as normas e princípios do Direito Internacional do Meio Ambiente, atualmente o grande propulsor de estudos e políticas na defesa e proteção da natureza humana. 


\title{
I - MEIO AMBIENTE E DIREITO INTERNACIONAL
}

\author{
1.1) Breve histórico do tratamento dado ao Meio Ambiente
}

O meio ambiente tal como é estudado atualmente, ou seja, as relações entre a biosfera e o seu meio circundante, em particular as características que lhe são mais peculiares, só passaram a integrar o universo jurídico no século XX.

A preocupação com um ambiente limpo e saudável existe no âmbito jurídico desde muito tempo atrás. Já na antiguidade havia normas sobre tais assuntos, porém, ligadas à noção do direito de vizinhança ou dos valores econômicos de desvalorização da propriedade, e sempre de maneira isolada e tópica, sem qualquer compartilhamento com outros componentes do meio ambiente ${ }^{7}$. Da mesma maneira, já existiam normas sobre a preservação de florestas ou reflorestamento para fins de construção de barcos desde o século XVI na península Ibérica. Tal preocupação, inclusive, pode ser objeto de precedente da atual preocupação com o meio ambiente, apesar do caráter eminentemente utilitarista e imediatista daquela legislação, bem como sua preocupação com elementos isolados do meio ambiente ${ }^{8}$.

Muitas convenções ou normas utilitaristas podem ser hoje consideradas integrantes do arcabouço da proteção do meio ambiente, porém, nada mais são do que arranjos administrativos de natureza comercial, com fim na preservação, por exemplo, dos cardumes de peixes, pela via de uma regulamentação uniformizada entre as legislações nacionais (e menos com a instituição de entidades internacionais de controle e aplicação das normas acordadas entre os Estados). Um exemplo desse tipo de regulamentação é a Convenção de Berna, entre Baden (entidade que à época tinha uma autonomia

\footnotetext{
${ }^{7}$ SOARES, G. F. S. Direito internacional do meio ambiente: emergência, obrigações e responsabilidades. São Paulo: Atlas, 2001, p. 39.

8 "Na mesma toada, algumas normas que surgiram sobre a proteção da caça e pesca em determinados períodos do ano são normalmente apontadas como precedentes da atual legislação de proteção ao meio ambiente; a problemática continua, uma vez que o que se visava, então, era a mera proteção de indivíduos, sem qualquer preocupação com a espécie e, tão pouco, com as relações entre elas e o meio ambiente e, consequentemente, com a vida humana, no conjunto da biosfera." SOARES, G. F. S. Direito internacional do meio ambiente: emergência, obrigações e responsabilidades. São Paulo: Atlas, 2001, p. 39.
} 
internacional, hoje, um Estado da Alemanha) e a Suíça ${ }^{9}$, bem como a Convenção de Basiléia, entre Baden, França e Suíça ${ }^{10}$.

Seguindo o mesmo modelo, vê-se que as legislações que regulamentavam certas poluições, como fumaça, barulho ou a degradação de águas doces correntes, eram isoladas, sem levar em conta o conjunto dos elementos que compõem o meio ambiente, elementos estes que são solidários entre $\mathrm{si}^{11}$.

Observa-se que as primeiras preocupações com o meio ambiente considerado como uma Gestalt na esfera jurídica surgiram com as legislações internas, já nos meados do século XX, elaboradas com base em situações emergenciais, catastróficas ou de grande comoção e geradoras de graves danos e ameaças à sanidade pública ${ }^{12}$. Nota-se que, enquanto a saúde das populações não passou a sofrer os efeitos negativos advindos do fato da acumulação de dejetos perigosos, por exemplo, não houve qualquer preocupação com a regulação da proteção ao meio ambiente como um todo.

Porém, à medida e à proporção que as concentrações populares, especialmente as urbanas, cresciam, com o consequente aumento do volume acumulado de lixo, somados aos dejetos industriais, começaram as autoridades a criar uma regulamentação sobre saúde pública, no âmbito ambiental, no interior das sociedades. Dessa forma, segundo Guido Fernando Silva Soares, o fenômeno da necessidade da proteção ao meio ambiente passou a ser considerado como um conjunto de elementos interligados e de causação recíproca entre eles, e como tal, principiou a ser tratado nos direitos internos dos países ${ }^{13}$.

\section{2) O surgimento do Direito Interno e Internacional do Meio Ambiente}

No que diz respeito às relações internacionais, a proteção do meio ambiente como valor e sua incidência no Direito Internacional é algo muito recente. Trata-se de trabalho

\footnotetext{
${ }^{9}$ Para o estabelecimento de regulamentações uniformes concernentes à pesca no Reno entre Constança e Basiléia, de 1869.

${ }^{10}$ Para o estabelecimento de regulamentações uniformes concernentes à pesca no Reno e nos seus tributários, inclusive o Lago de Constança, de 1875.

${ }^{11}$ No caso das águas salgadas, embora tenham conhecido uma regulamentação do Direito Internacional desde o século XVI (nas questões relacionadas à delimitação do alto-mar, por razões de assegurar-se nele a liberdade de navegação) somente experimentariam uma regulamentação de caráter preservacionista, no século XX.

${ }^{12}$ Especialmente alguns casos nos Estados Unidos da América e Europa.

13 SoARes, G. F. S. Direito internacional do meio ambiente: emergência, obrigações e responsabilidades. São Paulo: Atlas, 2001, p. 40.
} 
dificultoso identificar precedentes nos séculos anteriores, sobre normas relativas à proteção do meio ambiente ${ }^{14}$.

No que concerne à saúde humana, uma pesquisa sobre o Direito Sanitário Internacional revela que suas primeiras legislações surgiram para o combate às moléstias transmissíveis, em particular aquelas por via dos transportes internacionais e que se configuravam como epidêmicas ou de grande clamor. Não existem citações claras sobre preocupações ambientais constantes nos autores que estudaram o surgimento daquele direito $^{15}$.

Se nas relações internacionais o enfrentamento das correlações entre os conceitos de saúde e meio ambiente é tema moderno, elas não são estranhas ao estudioso da Medicina e do Direito Sanitário, numa perspectiva geral e filosófica. Conforme relata Sueli Dallari, Hipócrates já indicava a influência da cidade e do tipo de vida de seus habitantes sobre a saúde ${ }^{16}$.

Pascal Ascot, em sua obra História da Ecologia, revela as primeiras normas nacionais concernentes ao meio ambiente ${ }^{17}$. Os objetivos eram de, numa visão um tanto rousseauniana, preservar um paraíso, encerrando o que dele restava em santuários, como relíquias. Pode-se notar que àquela época ainda não havia perigo iminente da destruição do meio ambiente, bem como a idéia de frear o desenvolvimento industrial, particularmente nos Estados Unidos da América, que vivia uma filosofia baseada no fordismo.

O surgimento das primeiras legislações internas dos Estados com intuitos preservacionistas e com a tônica de um dever-ser oponível até contra uma política oficial de desenvolvimento industrial haveria de acontecer somente no século XX. Dessa forma, já no século XX, porém antes da Grande Guerra, as convenções internacionais sobre temas do meio ambiente eram eminentemente utilitárias e diziam respeito ao comércio mundial

\footnotetext{
14 Até mesmo os regulamentos do final do século XIX, que cuidam do regime jurídico dos rios internacionais, como o Reno e o Danúbio, revelam uma preocupação com critérios de delimitações de soberania dos Estados, ou ainda, de livre navegação (e, eventualmente, de necessidade de consultas recíprocas entre os Estados, quando da concretização de grandes obras hidráulicas que viessem a impedir ou dificultar a citada navegação internacional). SOARES, G. F. S. Direito internacional do meio ambiente: emergência, obrigações e responsabilidades. São Paulo: Atlas, 2001, p. 40.

${ }^{15}$ O Prof. Cino Vitta, em seu Curso na Academia da Haia, em 1930, notável precursor dos estudos do Direito Sanitário Internacional e, mais modernamente, o Prof. Michel Bélanger, em 1983, quedam silentes sobre as primeiras leis relativas à saúde pública e seu relacionamento com aquelas de proteção ao meio ambiente.

${ }^{16}$ Dallari, S. G. Os estados brasileiros e o direito à saúde. 1993. p. 4-5. Tese (Livre-Docência) Faculdade de Saúde Pública da Universidade de São Paulo, São Paulo, 1993 in SoAres, G. F. S. Direito internacional do meio ambiente: emergência, obrigações e responsabilidades. São Paulo: Atlas, 2001, p. 41.

${ }^{17}$ Em 1872, a criação do Parque Nacional do Yellowstone nos Estados Unidos da América, seguida dos Parques de Yosemite, General Grant, Sequoia e Mount Rainier, este último em 1899.
} 
de certas espécies animais, com finalidades de preservação dos indivíduos, para fins de exploração econômica, conforme indicado anteriormente ${ }^{18}$.

Não obstante esse início pouco claro do que deveria ser protegido, em matéria ambiental, e como isso efetivamente deveria ser feito, um fato de extrema importância, no entreguerras, foi a publicação da sentença final do famoso Caso da Fundição Trail (Trail Smelter), apontada por grande parte da doutrina, como a primeira manifestação formal do Direito Internacional do Meio Ambiente, quanto às relações bilaterais, e que serviria de precedente a inúmeras decisões arbitrais posteriores ${ }^{19}$.

No mesmo sentido, a doutrina dos internacionalistas tem indicado o importante Princípio 21 da Declaração de Estocolmo, adotado em 1972, como cristalização de uma das normas fundamentais do Direito Internacional do Meio Ambiente, conforme declarada por ocasião do julgamento do Caso da Fundição Trail. Deve-se acentuar que o mencionado Princípio 21, por sua relevância, foi reafirmado como Princípio $2^{\circ}$ da Declaração do Rio de Janeiro sobre Meio Ambiente e Desenvolvimento ${ }^{20}$.

De fato, a preocupação generalizada com a proteção do meio ambiente, bem como a consciência da necessidade de sua proteção no âmbito internacional, como se tem dito, é uma particularidade do século XX, mais precisamente, dos arredores dos anos 1960. O caso da Fundição Trail, de um contencioso arbitral bilateral restrito a Estados Unidos da América e Canadá, estender-se-ia, a partir de então, a outras situações bi ou multilaterais e passaria a ser invocado, em especial por tribunais arbitrais, como fundamentação de normas que passaram a ter um alcance global.

\footnotetext{
${ }^{18}$ Um exemplo simples pode ser visto com o caso da Convenção de 1883, assinada em Paris, para a proteção das focas de pele do Mar de Behring; tal convenção pretendia, conforme a visão daquela época, impedir a extinção da espécie, não pela idéia da preservação do equilíbrio ambiental do meio, mas em função de uma regulamentação do mercado internacional das peles de luxo. SOARES, G. F. S. Direito internacional do meio ambiente: emergência, obrigações e responsabilidades. São Paulo: Atlas, 2001, p. 43.

${ }^{19}$ É um caso solucionado em 1941, por um tribunal arbitral, que tratava de um embate apresentado pelos Estados Unidos da América contra o Canadá, devido a ocorrências danosas de poluição transfronteiriça suportadas por pessoas, animais e bens situados nos Estados Unidos da América, causadas por correntes de ar que traziam partículas e a fumaça tóxica (dióxido de enxofre) produzidas no Canadá, por uma empresa particular. A parte fulcral da sentença, assim está disposta: "nenhum Estado tem o direito de usar ou de permitir o uso de seu território de tal modo, que cause dano em razão do lançamento de emanações no, ou até o território de outro". SOARES, G. F. S. Direito internacional do meio ambiente: emergência, obrigaçõos e responsabilidades. São Paulo: Atlas, 2001, p. 44.

${ }^{20}$ O Princípio 21 da Declaração de Estocolmo de 1972 é o seguinte: “Os Estados têm, de acordo, com a Carta das Nações Unidas e os princípios do direito internacional, o direito soberano de explorar seus próprios recursos, conforme suas próprias políticas relativas ao meio ambiente, e a responsabilidade de assegurar que tais atividades exercidas dentro de sua jurisdição, não causem danos ao meio ambiente de outros Estados ou a áreas além dos limites da jurisdição nacional”. Organização das Nações Unidas. Declaração de Estocolmo. Estocolmo. 1972. Disponível em <http://www.silex.com.br/leis/normas/estocolmo.htm>. Acesso em: 03 dez. 2010.
} 
Excetuando o caso da Fundição Trail, segundo Alexandre Kiss, o ano de 1960 expôs o início de uma nova cruzada de consciência sobre os problemas ambientais no âmbito internacional, e que pode ser tido como a tônica da atualidade: "o meio ambiente é um valor complexo, que deve ser encarado como uma entidade concreta em relação ao seu componente, extremamente frágil e que necessita de proteção contra seu maior predador: o homem (que, afinal, é igualmente seu beneficiário)"21.

Assim, para observar o nascimento do Direito Internacional do Meio Ambiente, segundo Guido Fernando Silva Soares, devem ser estudados quatro fenômenos ocorridos a partir do final da Segunda Guerra Mundial, bem como a crescente conscientização do mundo, sobre a necessidade da proteção dos Direitos Humanos ${ }^{22}$ : “a) a abertura das discussões nos foros diplomáticos internacionais à opinião pública internacional (por força da extraordinária expansão dos meios de comunicação em massa) e a conseqüente valorização das teses científicas sobre os fatos relativos ao meio ambiente; b) a democratização das relações internacionais, com a exigência correlata da efetiva participação da opinião pública na feitura e nos controles de aplicação dos grandes tratados internacionais, por força da atuação dos Parlamentos nacionais na diplomacia dos Estados (a democratização da diplomacia é uma conquista definitiva do século XX); c) a situação catastrófica em que o mundo se encontrava, pela possibilidade de uma destruição maciça de grandes partes do universo, representada pela ameaça da utilização dos engenhos bélicos (relembre-se, 1960 é o auge da Guerra Fria), fabricados por meio da utilização militar da energia nuclear; e, d) a ocorrência de catástrofes ambientais, como os acidentes de vazamentos de grandes nuvens tóxicas (naquele então, de grandes proporções, mas não catastróficas como aconteceria em 1976, em Seveso, na Itália, considerado o maior desastre industrial da Europa Ocidental), ou grandes derramamentos de petróleo cru no mar, fenômenos que fizeram recrudescer as letais experiências da poluição indiscriminada e não localizada em um ponto geográfico, que poderia eventualmente ser controlada por uma única autoridade estatal" 23 .

\footnotetext{
${ }^{21}$ A idéia de fixar os arredores dos anos 1960, como a data do nascimento do Direito Internacional do Meio Ambiente é do Professor Alexandre Kiss, em sua obra Droit International de l'environnement, de 1989.

${ }^{22}$ Interessante notar que a Declaração Internacional dos Direitos do Homem, proclamação da Assembléia das Nações Unidas, é de 1948.

${ }^{23}$ Importante notar que se encontravam, pois, reunidas as duas primeiras questões que iniciam a elaboração do direito: a necessidade social e a vontade determinante de a fonte normativa produzir a regra jurídica. Da mesma forma, novos foros de discussão internacional começaram a surgir, como a Organização das Nações Unidas e as Organizações Não-Governamentais o que facilitaram o debate sobre a proteção do meio ambiente. Nesse sentido, as primeiras discussões sobre danos ambientais começaram com: a) a questão da poluição transfronteiriça, seja por água doce ou ar; e, b) a questão da poluição crescente e desenfreada dos mares e oceanos, por meio das três formas detectadas: 1. Alijamento; 2. Deposição; e, 3. "Poluição telúrica".
} 
A partir dos anos 1960, a movimentação dos Estados em busca de uma regulamentação global do meio ambiente foi exponenciada. Até a data de 1972, quando se realizaria a Conferência das Nações Unidas sobre o Meio Ambiente Humano, em Estocolmo, várias convenções internacionais afirmariam a pujança do Direito que então surgia, o Direito Internacional do Meio Ambiente, o qual teria sua certidão de maturidade plena firmada naquele evento na Suécia.

Assim, dentro de tal movimentação dos Estados e da atuação de sua Assembléia Geral (sob cuja égide importantes tratados e convenções passariam a ser negociados e assinados diretamente pelos Estados) ou de seus organismos especializados, a Organização das Nações Unidas, enquanto organização primeira das relações internacionais na atualidade, não poderia deixar de refletir a preocupação dos Estados e dos cidadãos quanto aos aspectos ambientais em âmbito mundial. Em 1968, sua Assembléia Geral, por meio da Resolução no 2.398 (XXIII), aprovaria a recomendação encaminhada por seu Conselho Econômico e Social, no sentido de convocar-se, o mais breve possível, uma Conferência Internacional sobre o Meio Ambiente Humano ${ }^{24}$. Tendo finalmente o governo sueco oferecido sua capital como sede do evento, em 1972, reuniu-se em Estocolmo a Conferência das Nações Unidas sobre o Meio Ambiente Humano, fato que, como já dito, selou a maturidade do Direito Internacional do Meio Ambiente ${ }^{25}$.

É assaz interessante tratar também da utilização da energia nuclear, fenômeno característico da segunda metade do século XX que, por sua vez, representa importante fator para o tema do meio ambiente. Sua relação com o Direito Internacional do Meio Ambiente tem dois pontos: a) A iminência de uma destruição em massa que pairava sobre todos; e, b) A emergência de uma legislação internacional preocupada com os legítimos fins pacíficos da energia nuclear. SOARES, G. F. S. Direito internacional do meio ambiente: emergência, obrigações e responsabilidades. São Paulo: Atlas, 2001, p. 46.

${ }^{24}$ A convocação foi possível após quatro anos de consultas aos Estados e de um grande trabalho preparatório; deve-se destacar a realização de um Painel de Peritos em Desenvolvimento e Meio Ambiente, celebrado em Founex, Suiça, em 1971, formado por especialistas de todas as regiões do mundo, cujo Relatório serviria de base a diversas outras reuniões regionais convocadas pelo ECOSOC. Nas reuniões preparatórias à Conferência de Estocolmo, ficaria evidente a oposição entre nações desenvolvidas e nações em desenvolvimento: aquelas propugnavam por uma reunião em que se desse ênfase aos aspectos relativos à poluição da água, do solo e da atmosfera, derivada da industrialização; as nações em desenvolvimento, por outro lado, opuseram-se, temendo que as eventuais políticas preservacionistas adotadas pudessem servir de instrumentos de interferência nos assuntos domésticos, provocando um arrefecimento das políticas internas de desenvolvimento industrial daqueles Estados, além de contestarem os elevados custos envolvidos na adoção de medidas conservacionistas em termos mundiais. SOARES, G. F. S. Direito internacional do meio ambiente: emergência, obrigações e responsabilidades. São Paulo: Atlas, 2001, p. 53.

${ }^{25} \mathrm{Na}$ ocasião, foram votados: 1. A Declaração de Estocolmo (Declaração das Nações Unidas sobre o Meio Ambiente), com seu Preâmbulo de sete pontos e 26 Princípios; 2. Um plano de Ação para o Meio Ambiente, conjunto de 109 recomendações, centradas em três grandes tipos de políticas: (a) as relativas à avaliação do meio ambiente mundial, o denominado "Plano Vigia" (Earthwatch); (b) as de gestão do meio ambiente; e (c) as relacionadas às medidas de apoio (como a informação, educação e formação de especialistas); 3 . Uma Resolução sobre os aspectos financeiros e organizacionais no âmbito da ONU; e, 4. A instituição de um organismo especialmente dedicado ao meio ambiente, o Programa das Nações Unidas sobre o Meio Ambiente (PNUMA - também conhecido por suas siglas, em inglês, UNEP, ou em francês, PNUE), órgão subsidiário da Assembléia Geral da ONU, com sede em Nairóbi, no Quênia. 
A Declaração sobre o Meio Ambiente Humano, surgida em Estocolmo pela Conferência das Nações Unidas sobre o Meio Ambiente Humano, de 1972, pode ser considerada como um documento com a mesma importância para o Direito Internacional que teve a Declaração Universal dos Direitos do Homem (adotada pela Assembléia Geral da ONU em 1945). De fato, ambas as Declarações têm cumprido o papel de verdadeiros guias e parâmetros na definição dos princípios mínimos que devem figurar tanto nas legislações domésticas dos Estados, quanto na adoção dos grandes textos de natureza constitucional. Tais Declarações ora solidificaram, em textos escritos, aqueles valores que já se encontravam estabelecidos nos sistemas jurídicos da maioria das Nações e nas relações internacionais, ora declararam outros novos, de conformidade com a emergente consciência da necessidade da preservação do meio ambiente global $^{26}$.

Importante destacar que, paralelamente às reuniões oficiais dos Estados, durante a Conferência de Estocolmo, aconteceu uma série de eventos científicos e artísticos promovidos pelas Organizações Não-Governamentais (ONGs), entidades privadas de defesa do meio ambiente, que demonstraram sua força como fatores de formação e conscientização da opinião pública mundial sobre as questões ambientais internacionais. A grande crítica que a mídia internacional, na ocasião, lançou contra os organizadores da conferência foi exatamente quanto à falta de sensibilidade e respeito deles com relação às mencionadas ONGs, patrocinadoras das denominadas "conferências selvagens", paralelas às sessões oficiais e, muitas vezes, de maior interesse político e científico que as reuniões dos representantes dos Estados $^{27}$.

\section{3) O conceito de Direito Internacional do Meio Ambiente}

Resumidamente, o Direito Internacional do Meio Ambiente, segundo Geraldo Eulálio do Nascimento e Silva, "trata dos direitos e das obrigações dos Estados e das organizações governamentais internacionais, bem como dos indivíduos na defesa do meio ambiente. $\mathrm{O}$ sujeito, por excelência, do direito ambiental internacional continua a ser o

26 SoAres, G. F. S. Direito internacional do meio ambiente: emergência, obrigações e responsabilidades. São Paulo: Atlas, 2001, p. 55.

${ }^{27}$ Deve-se registrar que uma das conseqüências da realização da Conferência de Estocolmo, no que se refere ao Brasil, foi ter a delegação brasileira, após a convenção, conseguido do Governo Federal a edição de um Decreto criando a Secretaria Especial do Meio Ambiente, que começaria suas atividades em janeiro de 1974. 
Estado, mas as organizações internacionais e intergovernamentais desempenham um papel cada vez mais importante na formulação e no seu desenvolvimento, sobressaindo a atuação das Nações Unidas e das principais organizações intergovernamentais, como o IMO, UNESCO, FAO e o PNUMA",28.

A evolução da proteção do meio ambiente ocorre no âmbito dessas organizações intergovernamentais. A resolução da Assembléia Geral ao tratar da Conferência das Nações Unidas para o Meio Ambiente e o Desenvolvimento (CNUMAD) pedia que as organizações internacionais e intergovernamentais dessem sua contribuição, insistindo que o Programa das Nações Unidas para o Meio Ambiente (PNUMA e UNEP) fosse o órgão de coordenação principal. Mas não coube somente ao PNUMA o trabalho preparatório, pois já se fazia presente a atuação de diversas organizações, muitas delas criadas antes do PNUMA (UNEP), e que, por força de suas respectivas competências, já possuíam uma capacidade específica para tratar do tema.

Obviamente, a Organização Mundial de Saúde (OMS) é a entidade mais qualificada para tratar de questões vinculadas à saúde, e igual entendimento se aplica à FAO no tocante à poluição por herbicidas e pesticidas, pesca e a defesa das florestas. Cabe à Organização Marítima Internacional (OMI) a principal responsabilidade quanto à poluição do mar e os problemas relativos ao clima e à sua transformação se centralizam na Organização Meteorológica Mundial (OMM). Nesta relação, devem ser ainda mencionadas a Organização Internacional do Trabalho (OIT), a Organização para o Desenvolvimento Industrial (UNIDO) e a Agência Internacional de Energia Atômica (AIEA).

\section{4) As fontes do Direito Internacional do Meio Ambiente}

O Direito Internacional do Meio Ambiente é formado pelas normas de Direito Internacional devidamente desenvolvidas, tendo em vista a proteção do meio ambiente. Em conseqüência, as suas fontes são praticamente as mesmas do Direito Internacional. Não é o objetivo dessa dissertação entrar na discussão doutrinária sobre a natureza das fontes de Direito Internacional e a sua hierarquia. Para o que se propõe nesse arrazoado, basta tomar por base o artigo 38 do Estatuto da Corte Internacional de Justiça que menciona os

\footnotetext{
${ }^{28}$ SILVA, G. E. do N. Direito ambiental internacional. $2^{\text {a }}$ Ed., Rio de Janeiro: Thex Ed., 2002, p. 5.
} 
tratados, o costume internacional, os princípios gerais do Direito, as decisões judiciárias e a doutrina dos autores mais qualificados.

\subsection{1) Os tratados}

Os tratados são a fonte maior do Direito Internacional do Meio Ambiente, sobretudo porque, nos últimos anos, o surgimento de regras tidas como de lege ferenda ainda não tiveram tempo de se consolidar. Além de outras vantagens, os tratados têm a virtude de determinar, de maneira clara os direitos e as obrigações das partes contratantes $^{29}$.

Dada a evolução exponencial do Direito Ambiental e as incertezas existentes quanto à planificação de determinados assuntos, tem ocorrido uma tendência de serem negociados tratados genéricos (em inglês denominados umbrella conventions), nos quais os grandes princípios são traçados, deixando-se a protocolos suplementares traçar as regras mais objetivas ${ }^{30}$.

Um excelente exemplo de tratado genérico e regional (ou sub-regional) é o Tratado de Cooperação Amazônica, que aborda superficialmente uma gama de assuntos que ficam na dependência de tratados específicos posteriores. No que diz respeito ao meio ambiente, o Tratado prevê que "tendo em vista a necessidade de que o aproveitamento da flora e da fauna da Amazônia seja racionalmente planejada, a fim de manter o equilíbrio ecológico da região e preservar as espécies, as Partes contratantes deverão adotar uma linha clara de medidas, como promover a pesquisa científica e o intercâmbio de informações e de pessoal técnico entre as entidades competentes dos respectivos países. Para alcançar os objetivos do Tratado, as Partes contratantes têm firmado tratados bilaterais que, com o correr do tempo, cobrirão todos os aspectos da proteção ambiental" ${ }^{\text {31 }}$.

Os tratados específicos podem versar não apenas sobre a proteção da flora e da fauna ou da proteção dos mares, rios, lagos ou da atmosfera e, em alguns casos, podem se preocupar especificamente com os problemas relativos à poluição.

\footnotetext{
29 SoAres, G. F. S. Direito internacional do meio ambiente: emergência, obrigações e responsabilidades. São Paulo: Atlas, 2001, p. 169.

30 Um exemplo é a Convenção de Viena para a Proteção da Camada de Ozônio (1985), que foi complementada pelo Protocolo de Montreal sobre substâncias que destroem a Camada de Ozônio (1987).

${ }^{31}$ SILVA, G. E. do N. Direito ambiental internacional. $2^{\text {a }}$ Ed., Rio de Janeiro: Thex Ed., 2002, p. 9.
} 
Uma crítica feita à maioria dos tratados ambientais é que padecem de clareza ou então evitam adotar regras claras e objetivas. Em outros termos, têm sido considerados soft law, muito embora esta expressão seja juridicamente falha. Mas, com o passar dos anos, é de se prever que a comunidade internacional tenderá a firmar tratados objetivos, como vem tentando na última década ${ }^{32}$.

\subsection{2) O costume como fonte do Direito Internacional do Meio Ambiente}

A soberania do costume na criação do Direito Internacional cessou depois da Segunda Guerra Mundial em virtude do aumento de membros da comunidade internacional e também em virtude do surgimento de novos e complexos problemas, dentre os quais os ambientais. No passado, o Direito Internacional era a concretização de usos e costumes aceitos por um número limitado de nações. O surgimento de inúmeros Estados e o seu ingresso nas Nações Unidas alterou esta situação e os países, na maioria afro-asiáticos, de forma breve demonstraram o seu empenho em deixar a sua marca no ordenamento mundial, através de convenções multilaterais negociadas sob a égide da ONU.

$\mathrm{Na}$ verdade, o costume tornou-se um critério insatisfatório e vagaroso para acompanhar a evolução do Direito Internacional. Segundo o Estatuto da Corte Internacional de Justiça, o costume como fonte do Direito Internacional deve justificadamente ser "prova de uma prática geral aceita como sendo o Direito". A compreensão deste preceito evoluiu muito desde 1920, quando foi incluído no Estatuto da antiga Corte. Com a rápida evolução do Direito Ambiental, os elementos materiais que eram exigidos para a constituição do costume transformaram-se; desde que se comprove

\footnotetext{
${ }^{32}$ Um exemplo é a já citada Convenção de Viena para a Proteção da Camada de Ozônio de 1985. Durante as reuniões do grupo de trabalho encarregado de preparar a Convenção, os países da Comunidade Européia eram contrários aos temas visando à diminuição na fabricação e consumo dos CFCs. Em 1987, depois de um verão rigoroso na Europa, o surgimento de um buraco na camada de ozônio acima da Antártida, as queimadas na Amazônia e os dados de cientistas sobre os efeitos nocivos do efeito estufa, fizeram com que a opinião pública européia passasse a exercer pressão e, quando da assinatura do Protocolo de Montreal sobre Substâncias que destroem a Camada de Ozônio, as delegações dos países da União Européia passaram a advogar soluções bem mais rigorosas do que as dos Estados Unidos da América, que deixaram de ser o país mais empenhado na adoção de medidas de controle de produção utilização dos CFCs. SILVA, G. E. do N. Direito ambiental internacional. $2^{\mathrm{a}}$ Ed., Rio de Janeiro: Thex Ed., 2002, p. 10.
} 
que uma "prática conseqüente é generalizada, nenhuma duração é requerida, uma prática prolongada não é necessária”, ${ }^{33}$.

Embora o costume tenha perdido a sua força em face dos tratados, a sua influência não pode ser menosprezada, principalmente em uma área, como a do Direito Ambiental, em que a evolução da matéria é exponencial, exigindo a adaptação das regras aceitas à realidade do momento, através de uma interpretação judiciosa dos textos ${ }^{34}$.

\subsection{3) Os princípios gerais do Direito}

Dentre as fontes do Direito Internacional indicadas pelo Estatuto da Corte Internacional de Justiça, os princípios gerais de Direito são os mais simples, tanto assim que existe uma tendência a negar seu valor como fonte, ao ponto de se afirmar que poderia ser, em última análise, aspecto do Direito costumeiro. A própria Corte, em mais de uma oportunidade, teve ensejo, sem utilizar a expressão "princípios gerais de Direito", de invocar princípios gerais, bem estabelecidos ou geralmente reconhecidos, sendo que não o $\mathrm{fez}^{35}$

Definitivamente, não cabe aqui abordar as teorias existentes a respeito. No período em que foi elaborado o Estatuto da Corte Permanente de Justiça Internacional era flagrante e impositiva a teoria do Direito Natural. O que se discute é se a expressão "princípios gerais de Direito" significa ou não os "princípios gerais de Direito Internacional", conforme pensam Anzilotti e Oppenheim ${ }^{36}$. Mas, outros autores julgam que a expressão se refere exclusivamente ao Direito interno. Aponta-se que, no caso do Direito Internacional do Meio Ambiente, uma interpretação ampla se impõe, dada a pobreza de regras existentes na matéria. As regras eventualmente derivadas dos princípios gerais de Direito, que venham a ser acolhidas pela opinio juris, assumem as características do costume, acarretando, em conseqüiência, o seu desaparecimento como tal ${ }^{37}$.

\footnotetext{
${ }^{33}$ Isto, contudo, não deve ser entendido como um endosso à idéia de um Direito Internacional instantâneo, de um direito internacional que surge de fato com a aprovação, por exemplo, de uma resolução no âmbito das Nações Unidas.

${ }^{34}$ SILVA, G. E. do N. Direito ambiental internacional. $2^{\text {a }}$ Ed., Rio de Janeiro: Thex Ed., 2002, p. 12.

${ }^{35}$ SILVA, G. E. do N. Direito ambiental internacional. $2^{a}$ Ed., Rio de Janeiro: Thex Ed., 2002, p. 14.

${ }^{36}$ SILVA, G. E. do N. Direito ambiental internacional. $2^{a}$ Ed., Rio de Janeiro: Thex Ed., 2002, p. 14.

${ }^{37}$ SILVA, G. E. do N. Direito ambiental internacional. $2^{\text {a }}$ Ed., Rio de Janeiro: Thex Ed., 2002, p. 14.
} 


\subsection{4) A jurisprudência dos Tribunais}

A Jurisprudência dos tribunais ou, para usar a terminologia do Estatuto da Corte Internacional de Justiça, "as decisões judiciárias", possuem uma posição importante no campo do Direito Internacional do Meio Ambiente, dada a influência exercida por três decisões nesta sua fase de formação, ou seja, o Caso da Fundição Trail, o caso do Canal de Corfu e o caso do Lago Lannoux.

Destes, o caso da Fundição Trail entre os Estados Unidos da América e o Canadá, conforme anteriormente indicado, é o mais importante. O modelo de solução do conflito aplicado, arbitragem, também demonstrou a importância do uso desse mecanismo para o Direito Internacional do Meio Ambiente. O caso da Fundição Trail resultou de uma arbitragem entre os Estados Unidos da América e o Canadá em abril de 1935, com o objetivo de dar uma solução final a um problema de poluição por dióxido de enxofre provocado pela fundição de zinco e chumbo em território canadense, com graves efeitos no Estado de Washington nos Estados Unidos da América. Na decisão final, datada de 11 de março de 1941, o Tribunal reconheceu existir um princípio de Direito Internacional segundo o qual "o Estado tem sempre o dever de proteger outros Estados contra atos injuriosos praticados por indivíduos dentro de sua jurisdição”. Em virtude deste princípio, o laudo arbitral diz o seguinte: "Nenhum Estado tem o direito de usar ou permitir o uso de seu território de tal maneira que emanações de gases ocasionem dano dentro do território de outro Estado ou sobre as propriedades ou pessoas que aí se encontrem, quando se trata de conseqüências graves e o dano seja determinado mediante provas certas e conclusivas".

O primeiro relator da Comissão de Direito Internacional sobre responsabilidade do Estado por atos não proibidos pelo Direito Internacional, Quentin Baxter, afirmou que quase todas as questões relacionadas com a poluição ambiental foram suscitadas pelo dissídio. Ainda subsistem dúvidas sobre o verdadeiro alcance da frase "conseqüências graves", bem como sobre o conceito de "provas certas e conclusivas" 38 .

Embora seja considerado o caso clássico do Direito Internacional do Meio Ambiente, o caso da Fundição Trail recebeu algumas críticas importantes, dentre elas, a de que foi baseada única e exclusivamente na jurisprudência dos Estados Unidos da América,

\footnotetext{
${ }^{38}$ SILVA, G. E. do N. Direito ambiental internacional. $2^{\text {a }}$ Ed., Rio de Janeiro: Thex Ed., 2002, p. 15.
} 
ou seja, reflete a common law como um todo, excetuando o Direito normatizado, onde a figura do abuso do direito seria mais apropriada para a resolução do problema. Resumidamente, "a principal conclusão que se pode tirar do laudo arbitral é que, de acordo com o Direito Internacional, um Estado é obrigado a tolerar as conseqüências de atividades de outro Estado, lícitas per se, embora afetando o seu território, até o momento em que tais efeitos extraterritoriais se traduzam em lesão ou prejuízo de consequiências sérias" 39 .

Outro caso de grande importância para o Direito Internacional do Meio Ambiente teve início em outubro de 1946, quando alguns navios de guerra britânicos receberam ordens de cruzar o canal de Corfu, situado entre a ilha do mesmo nome e a costa da Albânia, embora existisse a possibilidade de ser um caminho minado. Na ocasião, duas embarcações sofreram graves danos provocados pelas minas, inclusive com a morte de alguns tripulantes. Logo após o ocorrido, a Grã-Bretanha levou a questão à Corte Internacional de Justiça que, em julgamento de 04 de abril de 1949, decidiu, entre outras coisas, que a Albânia havia violado o Direito Internacional ao não dar conhecimento expresso do perigo que a eventual presença de minas representava para a navegação em suas águas territoriais. Dessa forma, ao decretar que "nenhum Estado pode utilizar o seu território para cometer atos contrários aos direitos de outros Estados", a Corte consagrou um princípio que foi acolhido pelo Direito Internacional do Meio Ambiente.

No caso Lannoux, apesar de não versar sobre questões de poluição transfronteiriça, a sentença arbitral que resolveu a demanda, em 19 de novembro de 1956, abordou a hipótese. Resumidamente, a questão consistia em saber se a França possuía o direito de utilizar as águas do lago em obras localizadas em seu território, sem que, com isto, a quantidade e a qualidade da água que passaria a ser recebida no lado espanhol fosse afetada. O Tribunal perpassou sobre a questão de uma eventual poluição em sua sentença, ao apontar que "se poderia alegar que os trabalhos poderiam provocar uma poluição definitiva nas águas do rio Carol, ou que as águas restituídas tivessem uma composição química ou uma temperatura ou outra característica que pudessem prejudicar os interesses espanhóis. Em tal caso, a Espanha poderia alegar que os seus direitos foram atingidos. Nem a documentação, nem os debates a respeito contêm qualquer alegação em tal sentido".

\footnotetext{
${ }^{39}$ SILVA, G. E. do N. Direito ambiental internacional. $2^{\text {a }}$ Ed., Rio de Janeiro: Thex Ed., 2002, p. 16.
} 
1.4.5) A doutrina dos autores mais qualificados

Na época em que houve a adoção do Estatuto da Corte Permanente de Justiça Internacional, a doutrina dos autores mais qualificados representava uma importante fonte do Direito Internacional. Com o passar dos anos, principalmente após a Segunda Guerra Mundial, observou-se no âmbito da Corte Internacional de Justiça uma ligeira tendência a não mais recorrer à doutrina, já que, no entender da Corte, um pronunciamento desta teria mais peso do que as opiniões isoladas de autores.

Entretanto, no caso do Direito Internacional do Meio Ambiente, a doutrina exerce papel primordial nesta fase em que os contornos da matéria são imprecisos. Será através da doutrina que estarão melhor delineados e aparentes os princípios que constituem o Direito Internacional do Meio Ambiente. No mais, observa-se que as várias organizações internacionais tendem a encarar as questões ambientais através de um prisma particularizado, ostentando a opinião de especialistas nem sempre formados dentro da ótica do Direito Internacional.

O Estatuto da Corte Internacional de Justiça, ao mencionar a doutrina dos publicistas mais qualificados, encara os juristas individualmente; no entanto, na busca da doutrina, é necessário recorrer ainda à contribuição de órgãos colegiados como os institutos não-governamentais, especialmente os dedicadas ao Direito Internacional. Os mais importantes em matéria de Direito Internacional são: o Institut de Droit International e a International Law Association, ambos fundados em 1873.

\subsection{6) As resoluções sobre Meio Ambiente das Organizações Internacionais}

O Estatuto da Corte Internacional de Justiça não aduz especificamente, dentre as fontes do Direito Internacional, as resoluções da Assembléia Geral das Nações Unidas e das demais organizações internacionais, sejam elas globais ou regionais. Em matéria ambiental algumas delas exercem grande influência, sendo que, em inúmeros casos, têm importância na formação do Direito.

Geraldo Eulálio do Nascimento e Silva citando Paul Reuter dá a finalidade correta de tal fonte e mostra que, do ponto de vista científico, na análise das recomendações, é 
necessário distinguir entre duas hipóteses: "ou a regra existia antes da intervenção das Nações Unidas e a Assembléia Geral equivale a um reconhecimento desta regra pela organização; ou então a regra ainda não existia e a resolução da Assembléia Geral como tal não obriga os Estados-membros; em compensação ele exerce certa pressão política sobre os Estados; se estes se conformarem com esta pressão, uma prática estatal pode se desenvolver e resultar depois de algum tempo na consciência de existir uma obrigação jurídica e resultar no nascimento de um costume" ${ }^{, 40}$.

Nesse sentido, algumas resoluções têm sido invocadas repetidamente na Assembléia Geral. Não há dúvida de que tais resoluções proeminentemente são aquelas que possuem efetivamente um conteúdo; as declarações puramente políticas não têm logrado resultado.

Na Declaração de Estocolmo sobre o Meio Ambiente Humano de 1972, dos princípios ali consagrados, efetivamente, o de $\mathrm{n}^{\mathrm{o}} 21$ é o mais importante. Nele se estabelece que "os Estados têm, de acordo com a Carta das Nações Unidas e os princípios de Direito Internacional, o direito soberano de explorar os seus recursos segundo as suas políticas ambientais, e a responsabilidade de garantir que atividades levadas a efeito dentro de sua jurisdição ou controle não prejudiquem o meio ambiente de outros Estados ou de áreas além dos limites da jurisdição internacional" ${ }^{41}$.

A segunda parte do princípio, ao reconhecer a responsabilidade das Nações pelas atividades que possam vir a afetar outros Estados ou áreas fora de sua jurisdição, embora não constante na Carta das Nações Unidas, pode ser considerada como aceita pelo Direito Internacional.

\subsection{7) As Organizações Não-Governamentais (ONGs)}

As Organizações Não-Governamentais (ONGs) têm um papel fundamental no desenvolvimento e na divulgação dos problemas relacionados à proteção do meio

\footnotetext{
${ }^{40}$ Em sua citação, Geraldo Eulálio do Nascimento e Silva não indica a fonte bibliográfica de Paul Reuter (1911-1990). Em pesquisa efetuada encontra-se que Reuter foi um internacionalista que atuou junto ao caso Lanoux. Silva, G. E. do N. Direito ambiental internacional. 2a Ed., Rio de Janeiro: Thex Ed., 2002, p. 19.

41 Embora dúvidas possam ser levantadas quanto à invocação da Carta e dos Princípios de Direito Internacional, o Princípio no 21 é considerado como sendo Direito costumeiro em matéria ambiental. O art. 195 da Convenção sobre o Direito do Mar de 1982 acolheu a primeira parte do princípio, que passou a ser, para os países a ele vinculados, de aceitação obrigatória.
} 
ambiente. A própria Assembléia Geral das Nações Unidas, ao convocar a Conferência do Rio de Janeiro sobre o Meio Ambiente e Desenvolvimento, demonstrou este fato ao solicitar que "as organizações não-governamentais com status consultivo junto ao Conselho Econômico e Social contribuam para o sucesso da Conferência”.

A contribuição das ONGs junto ao sistema das Nações Unidas é de fundamental importância. Atualmente em todas as instituições do sistema pode-se observar a participação ativa de ONGs cujo trabalho é possível de ser observado através da apresentação de relatórios e contra-relatórios que sustentam os mais diversos posicionamentos. Porém, talvez seja na área da proteção do meio ambiente que as ONGs têm exercido o seu papel mais importante ao endossar e defender posições advogadas pela opinião pública. São inúmeros os exemplos em tal sentido como na questão da condenação da pesca das baleias, na extinção dos elefantes, na condenação da poluição das águas do Mar do Norte, do Mar Báltico e do Mediterrâneo. Nos Estados Unidos da América, o presidente George W. Bush só aceitou o "Clean Air Act", cuja adoção era anátema do ponto de vista das indústrias do país, diante de um movimento social generalizado em todo os Estados Unidos da América ${ }^{42}$.

Várias são as organizações que tratam do meio ambiente pelo mundo, sobressaindo em sua atuação a Greenpeace, World Wild Foundation (WWF) e a Friends of the Earth. As ONGs são de vários tipos e formatos: internacionais, regionais ou nacionais; podem ser genéricas (tratando de todos os problemas relacionados ao meio ambiente), ou então, específicas, quando o seu objetivo se limita a determinado problema, como a proteção de espécies em extinção, ou de uma determinada espécie.

É importante salientar que as ONGs têm uma liberdade de ação negada às organizações intergovernamentais, que têm a sua liberdade de ação cerceada pelas políticas dos Estados-membros. Isso significa que as ONGs podem propor posições mais avançadas do que as resultantes de uma conferência intergovernamental.

1.5) Princípios do Direito Internacional do Meio Ambiente

\footnotetext{
${ }^{42}$ SILVA, G. E. do N. Direito ambiental internacional. $2^{\text {a }}$ Ed., Rio de Janeiro: Thex Ed., 2002, p. 21.
} 
O Direito Internacional utiliza-se de princípios gerais que servem como pontos de referência impregnados de valores tidos como importantes pela sociedade internacional e que fundamentam muitas das normas jurídicas no âmbito do Direito Internacional do Meio Ambiente. Tais princípios são tidos como conceitos genéricos com substrato normativo positivo associado às regras particulares e programas que podem ou não vinculá-los quando controvertidos em normas jurídicas ${ }^{43}$.

Alexandre Kiss, em seus estudos, observou que o sistema normativo internacional dá sustentação às medidas que objetivam proteger valores essenciais à sociedade, valores esses fundamentais, um dos quais é o meio ambiente ${ }^{44}$.

Os princípios gerais de Direito Internacional do Meio Ambiente podem ser observados como uma espécie de linha condutora que perpassa o ordenamento jurídico ambiental dando-lhe força, ao mesmo tempo em que lhe confere coesão ao nortear as ações necessárias aos Estados para prevenir, e até mesmo evitar, os efeitos nocivos no meio ambiente em prol do desenvolvimento de uma política ambiental comum. Portanto, podese notar que os princípios gerais de Direito Internacional do Meio Ambiente, apesar de possuírem caráter generalista, avalizam certa uniformidade à estruturação de regras jurídicas e trabalham como uma espécie de eixo dentro do qual certos valores fundamentais à comunidade internacional se apresentam.

Guido Fernando Silva Soares demonstra que os princípios gerais de Direito necessitam ser reconhecidos por outras fontes, notadamente pela jurisprudência internacional ou pela doutrina, para produzir efeitos jurídicos ${ }^{45}$, conforme anteriormente explicitado.

Nesse sentido, os tratados internacionais exercem um papel importante à construção de direitos voltados ao meio ambiente e solidificam, em seus preâmbulos, relevantes princípios gerais de Direito que facilitam a criação de um sistema normativo ambiental comum para algumas questões globais, como o da questão da mudança do clima. Nesse caso, cujo sistema jurídico internacional ainda está em formatação, os princípios gerais de Direito têm um papel sobressalente, conferindo uma dimensão de ponderação à formação das regras jurídicas. Esses princípios gerais podem ser considerados como motes ou linhas

${ }^{43}$ LiMA, L. F. A moldura regulatória internacional do mecanismo de desenvolvimento limpo do protocolo de Quioto. 2003. 349 p. Dissertação (Mestrado). Faculdade de Direito da Universidade de São Paulo, São Paulo, 2003.

${ }^{44}$ Kiss, A. Sustainable Development and Human Rights. In: Trindade, A. A. C. Direitos Humanos, Desenvolvimento Sustentável e Meio Ambiente. São José: IIDH, 1995, p. 37.

45 SoARes, G. F. S. Direito internacional do meio ambiente: emergência, obrigações e responsabilidades. São Paulo: Atlas, 2001, p. 198. 
de conduta fundamentais para a persecução da política ambiental comum dos Estados que expressam o comportamento indicado pela comunidade internacional à questão da mudança do clima, em especial para a implantação e supervisão das metas estabelecidas para a redução das emissões de gases de efeito estufa traçadas pelo Protocolo de Quioto ${ }^{46}$.

Segue abaixo alguns dos princípios gerais do Direito Internacional do Meio Ambiente, importantes para alicerçar as ações voltadas à emergência da proteção do Meio Ambiente.

1.5.1) O princípio da Cooperação Internacional e a Responsabilidade Comum, mas Diferenciada

Foi apenas a partir da segunda metade do século XX que os Estados iniciaram a aplicação do dever da cooperação, especialmente no meio ambiente, em suas políticas globais e em suas relações internacionais, com o intuito de resolver questões internacionais de caráter comum. O processo de cooperação internacional, embora tenha se iniciado no século XIX, aperfeiçoou-se com o estabelecimento do sistema das Nações Unidas em $1945^{47}$

No mesmo sentido, um novo estímulo em direção à construção do espírito de cooperação internacional deu-se com a Agenda 21, cujo capítulo $2^{\circ}$, alíneas 1 e 2 versam sobre a cooperação internacional tendente ao desenvolvimento sustentável dos países em desenvolvimento ${ }^{48}$.

${ }^{46}$ Os princípios arrolados na Declaração de Estocolmo de 1972 e aqueles relacionados na Declaração do Rio
de 1992 têm sido adotados em legislações internas de vários Estados e servido como base à formulação geral
de normas, procedimentos e atos.
${ }^{47}$ A Carta da ONU em seu capítulo 1 , artigo $1^{\circ}, \S 3^{\circ}$, coloca, como um de seus propósitos, "conseguir uma
cooperação internacional para resolver os problemas internacionais de caráter econômico, social, cultural ou
humanitário, e para promover e estimular o respeito aos direitos humanos e às liberdades fundamentais para
todos, sem distinção de raça, sexo, língua ou religião". Organização das Nações Unidas. Carta das Nações
Unidas. São Francisco. 1945. Disponível em <http://www.onu-brasil.org.br/doc1.php>. Acesso em: 16 nov.
2010 .
Agenda 21, Capítulo $2^{\circ}$, alíneas " 2.1 . Para fazer frente aos desafios do meio ambiente e do
desenvolvimento, os Estados decidiram estabelecer uma nova parceria mundial. Essa parceria compromete
todos os Estados a estabelecer um diálogo permanente e construtivo, inspirado na necessidade de se atingir
uma economia em nível mundial mais eficiente e equitativa, sem perder de vista a interdependência crescente
da comunidade das nações e o fato de que o desenvolvimento sustentável deve tornar-se um item prioritário
na agenda da comunidade internacional. Reconhece-se que, para que essa nova parceria tenha êxito, é
importante superar os confrontos e promover um clima de cooperação e solidariedade genuínas. É igualmente
importante fortalecer as políticas nacionais e internacionais, bem como a cooperação multinacional, para
acomodar-se às novas circunstâncias. 2.2 Tanto as políticas econômicas dos países individuais como as 
A cooperação internacional, no ambiente das tratativas multilaterais e nas reuniões diplomáticas internacionais, utiliza-se da diplomacia parlamentar multilateral para alicerçar as decisões dos Estados e, conseqüentemente, as relações jurídicas da sociedade internacional. A cooperação internacional pode ser observada como um importante princípio instrumental para o tratamento de temas atuais que necessitam do consenso das Nações e para a produção de novas diretrizes normativas ${ }^{49}$.

Como as questões físicas do meio ambiente não podem ser utilizadas como critérios de parâmetros para delimitar onde e quando aconteceu tal fato nocivo, torna-se relevante o emprego da cooperação internacional no combate à poluição transfronteiriça gerada pelas atividades do ser humano, como é o caso de poluição pela água e pelo ar. No caso do clima, o esforço conjunto realizado pelos diversos países permitiu o estabelecimento da Convenção Quadro das Nações Unidas sobre a Mudança do Clima e possibilitou o prosseguimento das negociações internacionais sobre o Protocolo de Quioto para se alcançar um consenso à aplicação de medidas, regras e procedimentos essenciais à sua implementação ${ }^{50}$.

relações econômicas internacionais têm grande relevância para o desenvolvimento sustentável. A reativação e a aceleração do desenvolvimento exigem um ambiente econômico e internacional ao mesmo tempo dinâmico e propício, juntamente com políticas firmes no plano nacional. A ausência de qualquer dessas exigências determinará o fracasso do desenvolvimento sustentável. A existência de um ambiente econômico externo propício é fundamental. O processo de desenvolvimento não adquirirá impulso caso a economia mundial careça de dinamismo e estabilidade e esteja cercada de incertezas. Tampouco haverá impulso com os países em desenvolvimento sobrecarregados pelo endividamento externo, com financiamento insuficiente para o desenvolvimento, com obstáculos a restringir o acesso aos mercados e com a permanência dos preços dos produtos básicos e dos prazos comerciais dos países em desenvolvimento, em depressão (...). As políticas e medidas necessárias para criar um ambiente internacional marcadamente propício aos esforços de desenvolvimento nacional são, consequentemente, vitais. A cooperação internacional nessa área deve ser concebida para complementar e apoiar - e não para diminuir ou subordinar - políticas econômicas internas saudáveis, tanto nos países desenvolvidos como nos países em desenvolvimento, para que possa haver um avanço mundial no sentido do desenvolvimento sustentável". Organização das Nações Unidas. Agenda 21. 1992. Disponível em <http://www.mma.gov.br>. Acesso em: 16 nov. 2010.

${ }^{49}$ Desse ângulo, a cooperação internacional é muito importante para proteção do meio ambiente na medida em que permite que se desenvolvam as estruturas e as ações necessárias à adoção e à aplicação de políticas globais por meio de tratados internacionais com base na soma dos esforços de colaboração entre os Estados.

${ }_{50}$ No estudo da cooperação internacional, Guido Fernando Silva Soares menciona que "o reconhecimento pelos Estados das necessidades de agirem em conjunto foi, na verdade, a descoberta de que, para a consecução de qualquer objetivo, em nível internacional, inclusive a própria sobrevivência, não haveria outra possibilidade senão conceber o Direito Internacional como um corpo de regras para o aperfeiçoamento desejável em suas relações recíprocas, pela via da cooperação. O dever de cooperação, assim, passa de um patamar de ideal a ser atingível, conforme constante nos grandes escritos dos filósofos dos séculos anteriores, para a realidade do dia-a-dia do Direito Internacional Público e da diplomacia dos Estados". SOARES, G. F. S. Curso de Direito Internacional Público, volume I. São Paulo: Atlas, 2002, p. 31. Já Salcedo explicita o significado da cooperação internacional do seguinte modo, "as noções de humanidade e de comunidade internacional não devem ser entendidas nem como novos sujeitos do Direito Internacional, nem como realidades que tenham se deslocado para os Estados e à soberania estatal, mas sim como pontos de referência que simbolizam a progressiva tomada de consciência dos interesses coletivos comuns que vão além dos interesses nacionais e que nos situam frente à intensificação e aprofundamento de uma das funções próprias do Direito Internacional desde sua origem: a dimensão da cooperação como realidade distinta de outra função 
Em seu princípio 24, a Declaração de Estocolmo demonstra a necessidade de cooperação entre os Estados para a derrubada dos efeitos nocivos trazidos pelas atividades humanas ao meio ambiente ao afirmar que "os assuntos internacionais que dizem respeito à proteção e melhoria do meio ambiente deverão se tratados num espírito de cooperação por todos os países, grandes e pequenos, em pé de igualdade. A cooperação através de convênios multilaterais ou bilaterais, ou de outros meios apropriados, é essencial para efetivamente controlar, prevenir, reduzir e eliminar os efeitos desfavoráveis ao meio ambiente, resultantes de atividades conduzidas em todas as esferas, levando-se em conta a soberania e interesses de todos os Estados"

As responsabilidades comuns, porém diferenciadas, mencionadas, reconhecem a distinção existente entre as Nações, em especial no que tange ao desenvolvimento econômico dos Estados desenvolvidos, que se encontram em uma posição de desenvolvimento superior ao dos Estados em desenvolvimento, e a sua responsabilidade histórica pelos efeitos nocivos que produziu no meio ambiente para alcançar tal posição. Esta distinção cria uma maior interdependência entre os Estados para a condução de medidas e processos relacionados à redução e à mitigação dos efeitos nocivos causados pela ação humana sobre o meio ambiente global.

Percebe-se assim que as medidas e ações necessárias para combater os problemas de degradação do meio ambiente dependem do consenso geral das Nações, da cooperação internacional e do balanceamento das obrigações entre os Estados para a perpétua proteção do sistema ambiental, com base na responsabilidade histórica e nas necessidades e circunstâncias nacionais dos países em desenvolvimento. A Convenção Quadro das Nações Unidas sobre Mudança do Clima exprime a necessidade da cooperação econômica entre os Estados em seu artigo $3^{\circ}, \S 5^{\circ} 52$.

básica do Direito Internacional, a coexistência entre os Estados Soberanos”. SALCEDo, J. A. C. Derecho Internacional em El Mundo em Cambio. Madrid: Tecnos, 1985, p. 198.

51 A Declaração do Rio de 1992 expressa o dever de cooperação entre os Estados em vários de seus princípios, dos quais se destaca o Princípio 7, dada a sua relevância instrumental para a Convenção Quadro sobre Mudança do Clima e para o Protocolo de Quioto. "Os Estados devem cooperar, em um espírito de parceria global, para a conservação, proteção e restauração da saúde e da integridade do ecossistema terrestre. Considerando as distintas contribuições para a degradação ambiental global, os Estados têm responsabilidades comuns, porém diferenciadas. Os países desenvolvidos reconhecem a responsabilidade que têm na busca internacional do desenvolvimento sustentável, em vista das pressões exercidas por suas sociedades sobre o meio ambiente global, e das tecnologias e recursos financeiros que controlam". Organização das Nações Unidas. Declaração do Rio. 1992. Disponível em <http://www.mma.gov.br>. Acesso em: 16 nov. 2010.

${ }^{52}$ Artigo $3^{\circ}, \S 5^{\circ}$ prescreve: "As partes devem cooperar para promover um sistema econômico internacional favorável e aberto, conducente ao crescimento e ao desenvolvimento sustentável de todas as Partes, em especial das Partes países em desenvolvimento, possibilitando-lhes assim, melhor enfrentar os problemas da mudança do clima. As medidas adotadas para combater a mudança do clima, inclusive as unilaterais, não 
Pode-se observar que a Convenção Quadro das Nações Unidas sobre Mudança do Clima, ao indicar a redução dos gases de efeito estufa aos níveis de emissões de 1990, leva em consideração também o comércio internacional e procura precaver-se de possíveis conflitos entre as políticas públicas a serem estabelecidas pelos Estados e as organizações internacionais que cuidam das relações comercias internacionais. As ações de combate aos problemas com o meio ambiente implicam na reavaliação da forma pela qual determinadas atividades produtivas são realizadas nos mais diversos setores de atuação das empresas e, portanto, necessitam de uma limitação do consumo de determinados bens, impondo, no tempo, novos modos de comportamento às sociedades humanas.

O Protocolo de Quioto, por sua vez, determina as condições operacionais e procedimentais necessárias à implantação da Convenção Quadro sobre Mudança do Clima. Este estabelece a meta de redução de emissões dos gases de efeito estufa das nações desenvolvidas no patamar de 5,25\% até 2012, utilizando por base os níveis existentes em 1990; e prevê, em seu artigo $2^{\circ}$, medidas ligadas direta ou indiretamente ao comércio internacional como “a) o aumento da eficiência energética em setores relevantes da economia nacional; a proteção e o aumento de sumidouros e reservatórios de gases de efeito estufa não controlados pelo Protocolo de Montreal, levando em conta seus compromissos assumidos em acordos internacionais importantes para o meio ambiente, a promoção de práticas sustentáveis de manejo florestal; b) a promoção de formas sustentáveis de agricultura; a pesquisa, a promoção, o desenvolvimento e o aumento do uso de formas novas e renováveis de energia, de tecnologias de seqüestro de dióxido de carbono e de tecnologias ambientalmente seguras; redução gradual ou eliminação de imperfeições de mercado, de incentivos fiscais, de isenções tributárias e tarifárias e de subsídios para todos os setores emissores de gases de efeito estufa que sejam contrários ao objetivo da Convenção e aplicação de instrumentos de mercado; c) medidas que limitem ou reduzam emissões de gases de efeito estufa e medidas para limitar e/ou reduzir as emissões de gases de efeito estufa não controlados pelo Protocolo de Montreal no setor de transportes; a limitação e/ou redução de emissões de metano por meio de sua recuperação e utilização no tratamento de resíduos, bem como na produção, no transporte e na distribuição de energia",53.

devem constituir meio de discriminação arbitrária ou injustificável ou restrição velada ao comércio internacional". Organização das Nações Unidas. Convenção Quadro das Nações Unidas sobre Mudança do Clima. 1992. Disponível em <http://www.onu-brasil.org.br/doc_clima.php>. Acesso em: 16 nov. 2010.

53 Organização das Nações Unidas. Protocolo de Quioto. 1997. Disponível em <http://www.onubrasil.org.br/doc_quioto.php>. Acesso em: 16 nov. 2010. 
No caso do princípio das responsabilidades comuns, mas diferenciadas, a Convenção do Clima o considera importante à realização de suas finalidades e à implementação das suas disposições ${ }^{54}$. O artigo $4^{\circ}, \S 1^{\circ}$ da Convenção da mesma forma prevê as responsabilidades dos Estados e as responsabilidades comuns, no entanto diferenciadas, em seu texto, responsabilidades estas ligadas ao dever de cooperação internacional, e reconhece, portanto, as diferenças e capacidades desiguais dos Estados à execução dos objetivos daquele tratado ${ }^{55}$.

O mesmo artigo, em seu $\S 2^{\circ}$, alínea "a”, trata do princípio das responsabilidades comuns, mas diferenciadas, ao enunciar que: “(...) Essas políticas e medidas demonstrarão que os países desenvolvidos estão tomando a iniciativa no que se refere a modificar as tendências de mais longo prazo das emissões antrópicas em conformidade com o objetivo desta Convenção (...)".

${ }^{54}$ Artigo $3^{\circ}$, § $1^{\circ}$ prescreve: "As Partes devem proteger o sistema climático em benefício das gerações presentes e futuras da humanidade com base na equidade e em conformidade com suas responsabilidades comuns mas diferenciadas e respectivas capacidades. Em decorrência, as Partes países desenvolvidos devem tomar a iniciativa no combate à mudança do clima e a seus efeitos”. Organização das Nações Unidas. Convenção Quadro das Nações Unidas sobre Mudança do Clima. 1992. Disponível em <http://www.onubrasil.org.br/doc_clima.php>. Acesso em: 16 nov. 2010.

55 Artigo 4, $\S 1^{\circ}$ prescreve "Todas as Partes, levando em conta suas responsabilidades comuns mas diferenciadas e suas prioridades de desenvolvimento, objetivos e circunstâncias específicos, nacionais e regionais, devem: a) Elaborar, atualizar periodicamente, publicar e por à disposição da Conferência das Partes, em conformidade com o Artigo 12, inventários nacionais de emissões antrópicas por fontes e das remoções por sumidouros de todos os gases de efeito estufa não controlados pelo Protocolo de Montreal, empregando metodologias comparáveis a serem adotadas pela Conferência das Partes; b) Formular, implementar, publicar e atualizar regularmente programas nacionais e, conforme o caso, regionais, que incluam medidas para mitigar a mudança do clima, enfrentando as emissões antrópicas por fontes e remoções por sumidouros de todos os gases de efeito estufa não controlados pelo Protocolo de Montreal, bem como medidas para permitir adaptação adequada à mudança do clima; c) Promover e cooperar para o desenvolvimento, aplicação e difusão, inclusive transferência, de tecnologias, práticas e processos que controlem, reduzam ou previnam as emissões antrópicas de gases de efeito estufa não controlados pelo Protocolo de Montreal em todos os setores pertinentes, inclusive nos setores de energia, transportes, indústria, agricultura, silvicultura e administração de resíduos; d) Promover a gestão sustentável, bem como promover e cooperar na conservação e fortalecimento, conforme o caso, de sumidouros e reservatórios de todos os gases de efeito estufa não controlados pelo Protocolo de Montreal, incluindo a biomassa, as florestas e os oceanos como também outros ecossistemas terrestres, costeiros e marinhos; e) Cooperar nos preparativos para a adaptação aos impactos da mudança do clima; desenvolver e elaborar planos adequados e integrados para a gestão de zonas costeiras, recursos hídricos e agricultura, e para a proteção e recuperação de regiões, particularmente na África, afetadas pela seca e desertificação, bem como por Inundações; f) Levar em conta, na medida do possível, os fatores relacionados com a mudança do clima em suas políticas e medidas sociais, econômicas e ambientais pertinentes, bem como empregar métodos adequados, tais como avaliações de impactos, formulados e definidos nacionalmente, com vistas a minimizar os efeitos negativos na economia, na saúde pública e na qualidade do meio ambiente, provocados por projetos ou medidas aplicadas pelas Partes para mitigarem a mudança do clima ou a ela se adaptarem; g) Promover e cooperar em pesquisas científicas, tecnológicas, técnicas, sócio-econômicas e outras, em observações sistemáticas e no desenvolvimento de bancos de dados relativos ao sistema climático, cuja finalidade seja esclarecer e reduzir ou eliminar as incertezas ainda existentes em relação às causas, efeitos, magnitude e evolução no tempo da mudança do clima e as conseqüências econômicas e sociais de diversas estratégias de resposta;". Organização das Nações Unidas. Convenção Quadro das Nações Unidas sobre Mudança do Clima. 1992. Disponível em <http://www.onu-brasil.org.br/doc_clima.php>. Acesso em: 16 nov. 2010. 
Assim, o princípio das responsabilidades comuns, mas diferenciadas, da Convenção intenta mostrar que os compromissos assumidos pelos Estados-partes em desenvolvimento dependem, em sua maioria, da assistência e cooperação dos países desenvolvidos para com o cumprimento das ações e programas instituídos no tratado, principalmente com relação aos custos, a transferência de tecnologias e de conhecimentos técnicos compatíveis com a sustentabilidade ambiental ${ }^{56}$.

\subsection{2) O Princípio do Poluidor Pagador}

Com o passar dos anos a sociedade passou a visar a natureza como um bem protegido que não entra na cadeia produtiva ou como um recurso natural voltado ao processo individualizado de produção. Os bens que se utilizam de recursos naturais, cujos custos e benefícios não recaem sobre a atividade de produção ou no consumo final dos bens produzidos, mas sobre a sociedade inteira ou parcela desta, são conhecidos como externalidades negativas do sistema produtivo e geram, por conseguinte, um custo social ${ }^{57}$.

Atualmente existe um ponto de saturação entre o sistema econômico e o sistema ambiental devido à utilização desmedida e contínua dos recursos naturais acomodados pelo sistema produtivo em consonância com a capacidade de reposição destes bens pela natureza. Para que aconteça a correção das externalidades negativas do processo de produção, ou custos sociais, há a obrigação de se congregar os custos ou benefícios que foram transferidos à comunidade pelo aparelho de mercado.

Dessa forma, a poluição, inclusive a transfronteiriça, deve ser considerada como uma externalidade negativa determinada pelas atividades humanas dentro do sistema econômico, com base no emprego de recursos naturais comuns, de acesso livre, cujas despesas do processo produtivo não são alocadas nas empresas, mas repassadas à sociedade ${ }^{58}$.

${ }^{56}$ LiMA, L. F. A moldura regulatória internacional do mecanismo de desenvolvimento limpo do protocolo de Quioto. 2003. 349 p. Dissertação (Mestrado). Faculdade de Direito da Universidade de São Paulo, São Paulo, 2003.

${ }^{57}$ LIMA, L. F. A moldura regulatória internacional do mecanismo de desenvolvimento limpo do protocolo de Quioto. 2003. 349 p. Dissertação (Mestrado). Faculdade de Direito da Universidade de São Paulo, São Paulo, 2003.

${ }^{58}$ Segundo Paulo de Bessa Antunes "uma externalidade ocorre quando a produção ou o consumo de um determinado bem, por um indivíduo ou empresa afeta diretamente os interesses de outro indivíduo ou empresa. O dano ambiental é um caso típico de externalidade, pois, na sua incidência sobre terceiros, inexiste 
De acordo com Fábio Nusdeo, "as externalidades econômicas negativas têm como causa fundamental a utilização de um fator escasso, sem preço, cuja natureza econômica está baseada na transferência não compensada de custos devido a uma falha no mecanismo institucional do sistema econômico, denominada falha de mercado. Portanto, a produção e/ou consumo de bens ou serviços geradores de efeitos externos não contabilizados em seu preço é considerada como uma falha de mercado",59.

O princípio do poluidor pagador, cuja base é econômica, está apontado na teoria apresentada por Arthur Pigou na década de 1920. Este opinava pela correção das externalidades de mercado por meio da aplicação de mecanismos econômicos. A correção das externalidades negativas pressuporia além do uso de instrumentos econômicos, a redução ou eliminação de bens, produtos e subprodutos que geram a poluição, quando necessário, e ou medidas impostas pela administração pública para a internalização dos custos sociais, sem que para isto seja obrigatório impedir exclusivamente as atividades produtivas $^{60}$.

Com o passar dos anos, o princípio do poluidor pagador tem sido empregado pelos governos para a reorganização dos custos de prevenção da poluição e de medidas de controle, como meio de se instigar o uso racional dos bens naturais escassos, a adoção de novas tecnologias e de equipamentos antipoluição pelo poluidor, permitindo, assim, a transferência do ônus econômico de prevenção ou correção novamente para o poluidor ${ }^{61}$.

A configuração para se combater a degradação ambiental de bens comuns globais deve sopesar a sustentabilidade dos recursos naturais e do desenvolvimento sócioeconômico, a partir de medidas de colaboração entre os Estados, de maneira a ensejar a responsabilização solidária e participativa das nações e da coletividade no combate à poluição transfronteiriça ${ }^{62}$.

qualquer mediação; ela é direta, sem qualquer mecanismo de mercado ou jurídico". ANTUNES, P. de. B. Dano Ambiental: Uma abordagem conceitual. Rio de Janeiro: Editora Lumen Juris, 2000, p. 214.

${ }^{59}$ Nusdeo, F. Desenvolvimento e Ecologia. São Paulo: Saraiva, 1975, p. 39 a 63.

${ }^{60}$ LIMA, L. F. A moldura regulatória internacional do mecanismo de desenolvimento limpo do protocolo de Quioto. 2003. 349 p. Dissertação (Mestrado). Faculdade de Direito da Universidade de São Paulo, São Paulo, 2003.

${ }^{61}$ Essa idéia foi reafirmada pelo Princípio 16 da Declaração do Rio ao demonstrar que os Estados devem auxiliar para a minimização da poluição gerada por meio de políticas internas que absorvam, através de instrumentos econômicos adequados, as externalidades econômicas negativas não contabilizadas nos custos de bens e serviços. O Princípio 16 da Declaração do Rio prescreve: "o poluidor deve, em princípio, arcar com o custo decorrente da poluição, as autoridades nacionais devem procurar promover a internalização dos custos ambientais e o uso de instrumentos econômicos, levando na devida conta o interesse público, sem distorcer o comércio e os investimentos internacionais". Organização das Nações Unidas. Declaração do Rio. 1992. Disponível em 〈http://www.mma.gov.br〉. Acesso em: 16 nov. 2010.

${ }^{62}$ De acordo com Cristiane Derani, a aplicação do princípio do poluidor pagador pode ser compreendida como uma espécie de "princípio de responsabilidade". DERANI, C. Direito Ambiental Econômico. São 
A utilização do princípio do poluidor pagador aos casos que envolvem medidas pró-ativas para impedir danos perigosos ou mesmo irreversíveis no âmbito da questão ambiental deve considerar as características peculiares dos bens que se pretende preservar ou abrandar, sem perder de vista os outros princípios aplicáveis à proteção do meio ambiente em geral.

Dessa forma, a busca do equilíbrio do sistema ambiental necessita de políticas internacionais que possibilitem à sociedade global se estruturar dentro de um conjunto de ações positivas, a partir de uma abordagem integrada e complementar que consinta no entrelaçamento do dever de precaução e de prevenção com a proteção ambiental unida à internalização das externalidades negativas produzidas pelo processo econômico.

\subsection{3) O Princípio da Prevenção e da Precaução}

O Princípio da Precaução demonstra a necessidade de se utilizar a cautela e o cuidado na aplicação de medidas que possibilitem causar a ameaça de danos sérios ou irreversíveis ao meio ambiente, mesmo em confronto com a ausência de absoluta certeza científica, ausência esta que não pode ser utilizada como razão para adiar medidas eficazes e economicamente viáveis para impedir ou prevenir a degradação ambiental ${ }^{63}$.

A Declaração de Estocolmo sobre o Meio Ambiente Humano de 1972 já revelava, em seu Princípio 2, a necessidade da prevenção e da precaução, da seguinte forma: "Os recursos naturais da terra incluídos o ar, a água, terra, a flora e a fauna e especialmente amostras representativas dos ecossistemas naturais devem ser preservados em benefício das gerações presentes e futuras, mediante uma cuidadosa planificação ou ordenamento" ${ }^{\text {. }}$.

A prevenção pode ser compreendida como um princípio fundamental que delineia as políticas voltadas ao meio ambiente e cujo objetivo primordial é a utilização racional e

Paulo: Max Limonad, 1997, p. 158. Já Paulo de Bessa Antunes acredita que deva ser aplicado como "um princípio que procura fazer com que o poluidor responda pelas ações ou omissões que tenham causado prejuízo ao meio ambiente, de tal modo que possa recuperar o meio ambiente que degradou, sem que os custos dessa recuperação recaiam sobre a sociedade, dando as penalidades ou medidas imputadas para esse fim um caráter mais educativo e pró-ativo do que coercitivo". ANTUnES, P. de B. Direito Ambiental. Rio de Janeiro: Ed. Lumen Juris, 1998, p. 31/32.

63 LIMA, L. F. A moldura regulatória internacional do mecanismo de desenolvimento limpo do protocolo de Quioto. 2003. 349 p. Dissertação (Mestrado). Faculdade de Direito da Universidade de São Paulo, São Paulo, 2003.

64 Organização das Nações Unidas. Declaração de Estocolmo. Estocolmo. 1972. Disponível em <http://www.silex.com.br/leis/normas/estocolmo.htm>. Acesso em: 03 dez. 2010. 
sustentável dos recursos naturais. Esse princípio aglutina a necessidade de se conduzir ações sociais à prática sustentável, com o afastamento, no tempo e no espaço, do perigo, na busca da proteção contra um dano que parece irreversível ou de difícil reparação e que possa vir a ocorrer no futuro ${ }^{65}$.

O artigo $3^{\circ}, \S 3^{\circ}$ da Convenção do Clima delimita: "As partes devem adotar medidas de precaução para prever, evitar ou minimizar as causas da mudança do clima e mitigar seus efeitos negativos. Quando surgirem ameaças de danos sérios ou irreversíveis, a falta de plena certeza científica não deve ser usada como razão para postergar essas medidas, levando em conta que as políticas e medidas adotadas para enfrentar a mudança do clima devem ser eficazes em função dos custos, de modo a assegurar benefícios mundiais ao menor custo possível. Para esse fim, essas políticas e medidas devem levar em conta os diferentes contextos socioeconômicos, ser abrangentes, cobrir todas as fontes, sumidouros e reservatórios significativos de gases de efeito estufa e adaptações, e abranger todos os setores econômicos. As Partes interessadas podem realizar esforços, em cooperação, para enfrentar a mudança do clima"66.

\subsection{4) O Princípio do Desenvolvimento Sustentável}

Primeiramente, cumpre explicitar que o princípio que será aqui delineado, apenas por questões didáticas, será feito em conformidade com o natural desenrolar dos princípios elencados pelo Direito Internacional do Meio Ambiente. Como a dissertação perpassa e tende a se aprofundar na matéria que aqui deveria estar disposta, opta-se por fazer uma breve menção à questão para um posterior desenvolvimento do tema e, após, melhor compreensão da finalidade do presente trabalho.

Com esse preâmbulo, pode-se apontar que, segundo a Comissão Mundial sobre Meio Ambiente e Desenvolvimento, que publicou o livro Nosso Futuro Comum, "o desenvolvimento sustentável é aquele que atende às necessidades presentes, sem comprometer a possibilidade de as gerações futuras atenderem às suas próprias

65 LiMA, L. F. A moldura regulatória internacional do mecanismo de desenolvimento limpo do protocolo de Quioto. 2003. 349 p. Dissertação (Mestrado). Faculdade de Direito da Universidade de São Paulo, São Paulo, 2003.

66 Organização das Nações Unidas. Convenção Quadro das Nações Unidas sobre Mudança do Clima. 1992. Disponível em <http://www.onu-brasil.org.br/doc_clima.php>. Acesso em: 16 nov. 2010. 
necessidades. Ele contém dois conceitos chaves: O conceito de 'necessidades', sobretudo as necessidades essenciais dos pobres do mundo, que devem receber a máxima prioridade; a noção das limitações que o estágio da tecnologia e da organização social impõe ao meio ambiente, impedindo-o de atender às necessidades presentes e futuras. Portanto, ao se definirem os objetivos do desenvolvimento econômico e social, é preciso levar em conta sua sustentabilidade em todos os países - desenvolvidos e em desenvolvimento"67.

A primeira idéia de se utilizar o termo desenvolvimento sustentável foi concebida em 1987 e expressada no Relatório Brundtland da Comissão Mundial sobre o Meio Ambiente e Desenvolvimento, apresentado à Assembléia Geral da ONU. Esse princípio, de efeito não obrigatório, pode ser observado como uma moldura que objetiva integrar estratégias e medidas voltadas às políticas ambientais e ao desenvolvimento socioeconômico dos países, fornecendo-lhes um caminho para a promoção da sustentabilidade em diversos campos da atuação humana ${ }^{68}$.

O Desenvolvimento Sustentável é um processo em constituição que objetiva o redimensionamento das atividades econômicas para se obter um melhor equilíbrio entre o meio ambiente, o homem e a sociedade, pressupondo a compreensão das dimensões ambiental, cultural, institucional, social e ética, bem como a adoção de estilos de atuação que promovam a proteção do meio ambiente e o desenvolvimento social de forma proba ${ }^{69}$. O equilíbrio que se aspira tem por objetivo a proteção dos processos ambientais essenciais que dão fulcro ao sistema da vida no planeta, e na qual está assente a sociedade humana, de forma que o emprego dos recursos naturais de forma equilibrada origine também o desenvolvimento econômico e o comércio internacional.

\footnotetext{
${ }^{67}$ Nosso Futuro Comum. Comissão sobre Meio Ambiente e Desenvolvimento. Rio de Janeiro. 1988.

${ }^{68}$ A Declaração de Estocolmo, em seus princípios, já expressava o conceito de desenvolvimento sustentável procurando, de alguma forma, integrar o social ao econômico, respeitando os limites finitos da natureza: "os recursos naturais da Terra, incluídos o ar, a água, o solo, a flora e a fauna e, especialmente, as parcelas representativas dos ecossistemas naturais, devem ser preservados, em benefício das gerações atuais e futuras, mediante um cuidadoso planejamento ou administração adequados”. Organização das Nações Unidas. Declaração de Estocolmo. 1972. Disponível em <http://www.silex.com.br/leis/normas/estocolmo.htm〉. Acesso em: 16 nov. 2010.

${ }^{69}$ Dupuy dita que "o conceito de 'desenvolvimento sustentável' foi forjado no quadro das Nações Unidas para tentar reconciliar os pontos de vistas divergentes dos países industrializados e dos países em desenvolvimento sobre a importância a ser acordada sobre a preocupação ambiental em suas políticas econômicas respectivas". DuPUY, P. M. Où em est droit international de l'environment à la fin Du siècle? Reveu Génerale de Droi Public, A. Pedone, Paris, Tome 101, 1997, p. 886.
} 


\section{II - DIREITO COMERCIAL, EMPRESAS E INTERNACIONALIDADE}

Findo o primeiro capítulo, sobre o Meio Ambiente e seus desdobramentos na esfera do Direito Internacional, faz-se necessária uma análise simplificada dos tópicos comércio, empresa e Direito. Observar como é formatada essa relação possibilitará, no capítulo seguinte dessa dissertação, entender como a relação entre empresa e meio ambiente culminou com o recebimento do desenvolvimento sustentável no âmbito da sociedade empresarial.

Essa compreensão será possível ao se estudar a história do comércio e conseqüentemente a posição expositiva do Direito Comercial e do Direito Empresarial, perpassando pelos conceitos básicos da empresa transnacional, que acaba por absorver de maneira mais contundente os princípios e normas do Direito Internacional do Meio Ambiente, tema central do trabalho.

\section{1) Breve histórico do Direito Comercial}

Pode-se, de maneira simplificada, conceituar que o Direito Comercial é o conjunto de ações exercidas rotineiramente no sentido da intermediação dentro da cadeia produtiva, com intuito lucrativo, vale dizer, o complexo de atos praticados habitualmente para levar produtos da sua fonte ao consumidor. Em uma concepção moderna, tal conceito não é afeito à realidade, uma vez que o Direito Comercial é muito mais complexo que o mero comércio de bens e serviços.

O comércio é atividade que remonta à Antiguidade da humanidade, existe notícia de tal atividade pelos mais variados povos, destacando-se em especial os fenícios. Todavia, não se pode dizer que existia uma regulação clara do comércio entre as partes, apesar de já existirem costumes devidamente aceitos.

Foi também na Antiguidade que surgiram as primeiras normas que regulavam de forma sintética o comércio, por volta de dois mil anos antes de Cristo. Exemplos são o Código de Manu na Índia e o Código de Hamurabi na Babilônia, ambos interessantes como pontos iniciais, entretanto, sem que pudessem conceituar o Direito Comercial. A cultura grega também possuía algumas normas, sem, contudo, normatizar um sistema unitário. No 
período de maior desenvolvimento romano, pode-se contar algumas normas que disciplinavam a atividade comercial, muitas delas incorporadas ao chamado ius civile, porém, mais uma vez sem autonomia própria como matéria. Isso muito em função da atividade predominantemente rural da base econômica daquela sociedade $\mathrm{e}^{70}$.

De fato, o Direito Comercial como sistema próprio, organizado e com unicidade somente surgiu na Idade Média com a necessidade de regular as relações entre os novos atores que se apresentaram ao mundo, os comerciantes. A atividade comercial ganhou força ao final desse período, mostrando o quão atrasados eram os normativos do Direito romano em matéria de atividade comercial.

Em um primeiro momento, inicia-se o desenvolvimento de um Direito Comercial, conforme explicitado anteriormente, baseado em costumes. Essa especialidade surge com a criação das corporações de mercadores (Gênova, Florença, Veneza), nascidas em virtude das condições avessas ao desenvolvimento do comércio. Com os poderes baseados especialmente na aristocracia e no secularismo das religiões, era preciso criar mecanismos que fortalecessem o compadrio dos comerciantes. Com o passar do tempo, o poder econômico e militar de tais corporações foi tão amplo que possibilitou operar a transição do regime feudal para o regime das monarquias absolutas de maneira efetiva. Segundo Carvalho de Mendonça, "o Direito Comercial surgiu, conforme se vê, não como obra legislativa nem criação de jurisconsultos, porém como trabalho dos próprios comerciantes, que o construíram com os seus usos e com as leis que, reunidos em classe, elaboraram"71.

Nesse período, os comerciantes estavam sujeitos a uma jurisdição especial (consular), distinta da jurisdição ordinária, o Direito Comercial somente se aplicava aos comerciantes. Em virtude das corporações de ofício, havia um chamado critério corporativo (sistema subjetivo) a que os membros de determinadas corporações estavam sujeitos. Após, o Direito aplicado seria o do próprio Estado, em função da ascensão burguesa ao poder, mantendo-se a disciplina autônoma. Dessa forma, pode-se afirmar que em um primeiro momento o Direito Comercial era o Direito dos comerciantes.

Com o intuito de melhorar cada vez mais a atividade-fim, os comerciantes criaram mecanismos acessórios ao comércio que logo se tornaram atividades autônomas. São exemplos de ato especifico o título cambiário e, de atividade específica, as instituições

${ }^{70}$ Carvalho de Mendonça, J. X. Tratado de direito comercial brasileiro. Atualizado por Ricardo Negrão. Campinas: Bookseller, 2000, v. 1, p. 63.

71 Carvalho de Mendonça, J. X. Tratado de direito comercial brasileiro. Atualizado por Ricardo Negrão. Campinas: Bookseller, 2000, v. 1, p. 69. 
bancárias. Esses atos acessórios foram tão bem recebidos que com o passar dos anos passaram a ser utilizados até por quem não praticava atos de comércio.

Com essas inovações e com o acelerado crescimento da atividade mercantil, já não era suficiente o conceito de Direito Comercial como Direito dos comerciantes, era importante estender seu âmbito de aplicação para disciplinar também as relações que não envolviam esse grupo. Nesse segundo momento, desenvolve-se o que os comercialistas chamam de sistema objetivista, o qual desloca o centro do Direito Comercial para os chamados atos de comércio. Esse modelo objetivista foi adotado formalmente pela primeira vez com o Código Comercial napoleônico, o qual influenciou diretamente a elaboração do Código Comercial brasileiro de 1850, posteriormente complementado pelo Regulamento 737 de 1850.

Com o desenvolvimento das atividades comerciais e o surgimento profissionalizado das empresas, nasce uma nova concepção que qualifica o Direito Comercial como o Direito das empresas, orientação maciçamente adotada na doutrina brasileira ${ }^{72}$, apesar de uma parte dos estudiosos ainda transparecer alguma resistência ${ }^{73}$. Nesta fase histórica, o Direito Comercial reencontra sua justificação não na tutela do comerciante, mas na tutela do crédito e da circulação de bens ou serviços ${ }^{74}$.

De forma simples, a empresa como ente econômico é a organização de capital e trabalho com fim à produção ou troca de bens, em um sentido unitário, a empresa tem algo estruturado para produzir ou fazer circular bens ou serviços. A visão jurídica da empresa sempre intentou ter como base a sua concepção econômica, entretanto deparou-se com a dificuldade de estabelecer um conceito unitário.

Nos estudos de Alberto Asquini já se observa na legislação, diferentes significados para o termo empresa, ora para indicar o sujeito que exercita a atividade organizada; ora para referir-se ao conjunto de bens organizados; ora ao exercício da atividade organizada; e, às vezes, à organização de pessoas que exercitam atividade econômica ${ }^{75}$.

Nesse sentido, têm-se os comentários de Barreto Filho: "Mas o enxerto no sistema jurídico, da noção econômica de empresa, não se fez sem dificuldades, nem se revelou apto a solucionar todos os problemas decorrentes. A verdade é que as várias leis passaram a

${ }^{72}$ ReQuião, R. Curso de direito comercial. 25 ed. São Paulo: Saraiva, 2003, v. 1, p. 15; FrAnCO, V. H. de M. Lições de direito comercial. 2 ed. São Paulo: Maltese, 1995, p. 51; CoElho, F. U. Curso de direito comercial. 4 ed. São Paulo: Saraiva, 2005, v. 1, p. 27; Bulgarelli, W. Direito Comercial. 14 ed. São Paulo: Atlas, 1999, p. 17.

${ }^{73}$ Martins, F. Curso de direito comercial. 22. ed. Rio de Janeiro: Forense, 1998, p. 29.

74 Auletta, G. L'impresa dal Códice di Commercio del 1882 al Codice Civile del 1942. In: 1882-1982 Cento Anni dal Codice di Commercio. Milano: Giuffrè, 1984, p. 81. 
utilizar o termo empresa em diversas acepções sem cuidar de empregá-lo sempre no mesmo sentido. De tudo isso resulta que não se chegou, no âmbito da teoria dos atos de comércio, a fixar uma concepção unitária de empresa" ${ }^{\text {76 }}$.

$\mathrm{Na}$ mesma linha de entendimento, tem-se Rubens Requião, demonstrando que as tentativas de criação de um conceito jurídico próprio para a empresa, não foram ainda bem sucedidas, pois que a tutela jurídica recai sobre a atividade do empresário ${ }^{77}$.

Ao tratar da concepção jurídica de empresa como "atividade econômica organizada, exercida profissionalmente pelo empresário, através do estabelecimento", Waldírio Bulgarelli demonstra que o conceito de empresa, na transposição do âmbito econômico para o jurídico, padece de uma transmudação de organização da atividade econômica para o exercício profissional da atividade econômica organizada, portanto, sob a égide do empresário $^{78}$.

Essa transmudação dá à empresa certo sentido de abstração, tal como considera Hentz, ao afirmar que a empresa "É apenas a organização dos fatores de produção posta a funcionar pelo empresário. Desaparecendo o exercício da atividade organizada, desaparece a empresa, que é apenas uma idéia abstrata"79.

Tais concepções são absorvidas pelo Direito brasileiro que, por sua vez, tem esteio no Direito e doutrina italianos. Muito embora a expressão Direito Empresarial seja atualmente de uso corriqueiro, o seu uso no ordenamento brasileiro se consubstancia no Código Comercial de 1850 e leis posteriores, onde, na afirmação de Almeida "criou-se um regime jurídico para o comerciante de ônus, obrigações, responsabilidades e proteção", e complementando, "paralelamente a esse regime jurídico-legal de regulamentação do comerciante (art. $4^{\circ}$ do Código Comercial) é que podemos verificar a existência da empresa" ${ }^{\circ 0}$.

Apesar de tais incongruências, não cessa a preocupação de busca de uma concepção unitária de empresa que corresponda às necessidades de natureza jurídica. Dois aspectos concorrem para isso. Um deles é composto de várias afirmações e proposições que se criaram no âmbito da construção doutrinária do Direito no tocante às empresas. $\mathrm{O}$ outro aspecto diz respeito às próprias transformações de características da vida contemporânea,

\footnotetext{
75 AsQuINI, A. Profili dell'Imprensa. Rivista del Diritto Commerciale, fascs. 1 e 2, 1943, p. 1.

${ }^{76}$ BARreto Filho, O. Teoria do estabelecimento comercial. 2 ed. São Paulo: Saraiva, 1988, p. $24 / 25$.

${ }^{77}$ ReQuiño, R. Curso de Direito Comercial. 25 ed. São Paulo: Saraiva, v. 1, 2003, p. 49.

${ }^{78}$ Bulgarelli, W. Direito Comercial. 14 ed. São Paulo: Atlas, 1999, p. 23.

${ }^{79}$ HentZ, L. A. S. Direito empresarial: doutrina - jurisprudência. 2.ed. Leme: Editora de Direito, 1998, p. 57.
} 
em que, no dizer de Fábio Konder Comparato, "é inegável que a evolução econômica conduziu aos conglomerados, aos grupos de empresas e às sociedades multinacionais" com mudanças profundas na organização interna e acarretando expectativas de reflexos significativos no sistema de Direito Empresarial ${ }^{81}$.

Dessa forma, faz-se interessante percorrer o estudo da empresa observando a evolução que realça a presença marcante e cada vez mais intensa na vida social e que tem inclusive provocado uma gradual substituição do termo Direito Comercial pelo termo Direito Empresarial, demonstra igualmente a caracterização da empresa com base nos conceitos de atividade e de organização, o que poderia indicar que são eles os possíveis elementos unificadores em uma concepção jurídica.

Efetivamente, com tais características solidificadas, pode-se interpretar melhor a absorção de normas e princípios internacionais em seu âmbito de atuação.

\section{2) Conceito econômico de comércio}

Segundo J. B. Say, como fator social e econômico, o comércio é uma atividade humana que coloca em circulação a riqueza acumulada, aumentando-lhe a utilidade, o que demonstra que, mais do que troca, o comércio é aproximação ${ }^{82}$.

No estudo da República de Platão, pode-se observar que o filósofo grego, ao questionar a origem da justiça, indaga inicialmente sobre as origens do Estado. Em suas conclusões, ao declarar que é impossível os seres humanos se saciarem de todas as suas necessidades com as suas próprias aptidões e recursos, percebe-se que são levados a se aproximarem uns dos outros para trocar os produtos excedentes de seu trabalho. Dessa forma, os seres humanos tendem à vida em grupo, constituindo-se em sociedades ${ }^{83}$. Essa fase inicial da sociedade é fortemente influenciada pela permuta dos produtos, frutos do trabalho individual, efetuada diretamente de produtor a consumidor, em movimento próximo do equânime. Costumou-se chamar esse movimento de economia de troca.

80 AlmeidA, M. P. S. F. Normas jurídicas empresariais. In HentZ, L. A. S. (coord) Obrigações empresariais. Franca: Unesp, 1998, p. 25/26.

${ }^{81}$ COMPARATO, F. K. Direito empresarial: estudos e pareceres. São Paulo: Saraiva, 1995, p. 24.

${ }^{82}$ SAY, J. B. Tratado de economia política. Tradução de Balthazar Barbosa Filho. São Paulo: Abril Cultural, 1983.

${ }^{83}$ Platão. A República. São Paulo: Martin Claret, 2000. 
É entendível que, em função do desenvolvimento da civilização ${ }^{84}$, o sistema de forças foi tornando-se mais complexo. Dessa situação começa a surgir uma mercadoriapadrão, que serve de intermediária no processo circulatório. Conchas, animais - sobretudo bois (pecus - pecúnia) - e, após, metais preciosos, enquadrando-se como denominador comum do valor, facilitando as trocas. É o nascimento da moeda no sistema comercial.

Com essa padronização monetária, a economia de troca (escambo, permuta) reinventa-se para a economia de mercado (economia monetária). Os produtores já não visam mais produzir em função de transpasse imediato de uma mercadoria específica de que outro possua, e sim passam a produzir para vender, adquirindo moeda, para aplicá-la como capital em novo ciclo de produção. Dessa forma, pode o produtor especializar-se em um só tipo de bem, para o qual se considera mais experimentado ou que melhor proveito lhe proporciona.

É nesse sentido que se observa o surgimento do aparelhamento do comércio para desempenhar a sua função econômica e social, aproximando indivíduos e unindo os povos, tornando-se, em uma perspectiva positiva, elementos de paz e solidariedade, em uma intensa ação civilizadora. Assim, em sua base formadora, o comércio tem arraigada a idéia de troca, que pode ser visualizada como o tráfico mercantil, expressão comum para designar a atividade comercial entre sociedades. Nesse aspecto, tem-se que, com o passar do tempo, para vender o trabalho produzido surgiu a necessidade de transportá-lo de um local para outro, onde sua existência fosse escassa ou nula, adquirindo-se maior utilidade tal como preconizado nos estudos econômicos. A noção econômica indicada por Alfredo Rocco é bastante precisa: "O comércio é aquele ramo de produção econômica que faz aumentar o valor dos produtos pela interposição entre produtores e consumidores, a fim de facilitar a troca de mercadorias" $\$ 5$.

No entendimento de Stuart Mill existe uma síntese que demonstra a necessidade do comércio prosperar através da figura do comerciante e seu empreendedorismo: "Quando as coisas têm que ser trazidas de longe, uma mesma pessoa não pode dirigir com eficácia, ao mesmo tempo, a manufatura e a venda a varejo; quando, para que resultem mais baratas ou melhores, se fabricam em grande escala, uma só manufatura necessita de muitos agentes locais para dispor de seus produtos, e é muito mais conveniente delegar a venda a varejo a outros agentes; e até os sapatos e os trajes, quando se tem de fornecer em grande escala de uma vez, como para abastecer um regimento ou um asilo, não se compram diretamente aos

\footnotetext{
${ }^{84}$ Uma das definições políticas de civilizar é multiplicar as necessidades.

${ }^{85}$ RocCO, A. Princípios de Direito Comercial. São Paulo: Saraiva, 1931
} 
produtores, mas a comerciantes intermediários, que são os que melhor sabem, por ser este o seu negócio" $"$.

No que concerne à noção inicial de empresa, essa advém da economia, ligada a idéia central da organização dos fatores de produção (capital, trabalho e natureza), para a realização de uma atividade econômica. Segundo Fábio Nusdeo a "empresa é a unidade produtora cuja tarefa é combinar fatores de produção com o fim de oferecer ao mercado bens ou serviços, não importa qual o estágio da produção" ${ }^{\prime 7}$. No mesmo sentido segue posição de Joaquín Garrigues, afirmando que "economicamente a empresa é a organização dos fatores da produção (capital, trabalho) com o fim de obter ganhos ilimitados" ${ }^{\prime \prime}$.

Assim, é com a conceituação econômica que se alcança o conceito jurídico de empresa, o qual, segundo Asquini, não é revelado claramente pelo direito positivo, nem mesmo nos países onde a teoria da empresa foi inicialmente positivada ${ }^{89}$. Segundo Bulgarelli, por tratar-se de um conceito cuja origem é econômica, pretendeu-se por um tempo negar a importância de tal denominação, iniciando-se uma cruzada para criar uma acepção jurídica completamente pura. No entanto, as tentativas que surgiram demonstraram ser infrutíferas, mantendo-se assim a idéia de que, preponderantemente, o conceito jurídico se assenta no conceito econômico, uma vez que o fenômeno é econômico, sociológico, religioso ou político concomitantemente e, portanto, deve ser estudado do ponto de vista jurídico ${ }^{90}$.

\section{3) Conceito jurídico de comércio}

Com a definição do conceito econômico do comércio, em tese seria algo fácil construir um conceito jurídico que lhe fosse assimilável e dessa forma obter uma definição inicial de Direito Comercial. No entanto, no momento em que o Direito se ocupa das atividades do comércio, para judicializá-lo com regras perenes, amplia por demais o seu conceito. Nesse sentido, o conceito econômico não se ajusta nem coincide com o seu conceito jurídico. Várias atividades que estão relacionadas com a circulação da riqueza -

\footnotetext{
${ }^{86}$ Mill, J. S. Princípios de Economia Política. México: Ed. Fondo de Cultura Económica, 1943.

${ }^{87}$ NuSDEO, F. Curso de economia: introdução ao direito econômico. São Paulo: RT, 1997, p. 285.

${ }^{88}$ GARRIGUeS, J. Curso de derecho mercantil. 7. ed. Bogotá: Temis, 1987, Tomo I, p. 162.

${ }^{89}$ AsQUINI, A. Profili dell'impresa. Rivista di diritto commerciale, Vol. XLI - Parte I, p. 1-20, 1943, p. 1.

${ }^{90}$ Bulgarelli, W. Tratado de direito empresarial. 3. ed. São Paulo: Atlas, 1997, p. 127.
} 
tais como as empresas agrícolas e artesanais, mineração, os negócios mobiliários - fogem do conceito jurídico de comércio, embora se compreendam em seu conceito econômico. Da mesma forma, muitas atividades, que escapam ao conceito econômico, congregam-se no seu conceito jurídico, alguns exemplos são as letras de câmbio e as notas promissórias, que podem ser sacadas ou emitidas por pessoas não-comerciantes para fins civis.

Dessa forma, os estudiosos do Direito procuram um conceito jurídico próprio para o comércio, abrangendo toda a sua complexidade. É de Ulpiano a definição: Lato sensu commercium est emendi, vendendiqu invicem jus ${ }^{91}$. Todavia, esse direito de comprar e vender reciprocamente não é capaz de fundamentar um conceito jurídico para o comércio.

É com Vidari que alguns juristas baseiam a definição jurídica para o comércio. Um exemplo é Inglêz de Souza, que a considera assaz satisfatória: "É o complexo de atos de intromissão entre o produtor e o consumidor, que, exercidos habitualmente com fim de lucros, realizam, promovem ou facilitam a circulação dos produtos da natureza e da indústria, para tornar mais fácil e pronta a procura e a oferta"92. Em virtude dessa conceituação é possível observar três elementos componentes do comércio, essenciais para a sua caracterização jurídica e a do comerciante: mediação, fim lucrativo e profissionalidade (habitualidade ou continuidade).

Por ser o ponto que é mais ligado aos efeitos do meio ambiente junto ao comércio, opta-se nesse momento em discorrer apenas sobre o elemento fim lucrativo ou lucratividade. A necessidade de sua conceituação e entendimento é indubitavelmente proporcional à relevância das políticas ambientais. O elemento de lucratividade pode ser considerado como um ponto essencial para a conceituação jurídica do comércio e serviu de base para vários juristas. Estes consideraram a lucratividade como ponto importante da definição de que o comércio é o conjunto de operações que tem por fim realizar proveito e lucro, especulando sobre a transformação, transporte ou troca de matérias-primas.

Utilizar o escopo lucro, atualmente, não é sinal de modernidade. São várias as atividades lucrativas que escapam ao âmbito do comércio no sentido jurídico, e outros atos tidos como de comércio, como um aval em letra de câmbio, que podem não ter a finalidade de se buscar lucro. Institucionalmente, pode-se observar a presença de empresas estatais que, ao passo que o Estado entra na seara econômica, podem não ter fim lucrativo e, no entanto, não se deve negar que também se integram ao comércio.

\footnotetext{
91 "O comércio é o direito de comprar e vender reciprocamente".

${ }^{92}$ De SouZA, I. Preleções de Direito Comercial. 5 ed. Rio de Janeiro: Livraria Jacinto, 1935.
} 
Jean van Ryn acredita que, dessa forma, a utilidade da noção de lucro é por demais reduzida para conceituar juridicamente o comércio, ou melhor, o Direito Comercial, colocando-o em plano secundário ${ }^{93}$. Ferrer Correia complementa que "essa correspondência entre o conceito de Direito Comercial e o de comércio perdeu-se de há muito. E a dificuldade não se resolve fazendo distinção entre o conceito econômico e o conceito jurídico de comércio, pois ao que se chama comércio neste último sentido não é senão ao conjunto das atividades a que, em determinado país, em dada conjuntura histórica, se aplica o Direito Comercial desse país, e muitas dessas atividades não se podem justamente definir como comerciais. Logo, a referida distinção é artificiosa" ${ }^{94}$.

Todavia, apesar do elemento lucratividade ser perpassado ao largo da conceituação jurídica do comércio, sua importância na atuação das empresas é extremamente relevante, especialmente nas empresas que, por sua atividade, podem causar danos ao meio ambiente. Dessa forma, ainda nesse capítulo, será tratada a conceituação de empresa, dando continuidade ao estudo de suas práticas e, efetivamente, do escopo desse trabalho.

\section{4) Direito Econômico e Direito Comercial}

O caminho dificultoso de se definir o Direito Comercial como Direito próprio ao comércio surge do fato de que, atualmente, o Direito Comercial deixou de ser, apenas, um Direito da atividade mercantil. Abrange muitos institutos e instituições que não são necessariamente comerciais.

Essa situação é frontalmente evidenciada com Jean van Ryn ao fazer a crítica da expressão comercial. Segundo o citado jurista, tal expressão era admissível no passado quando atendia efetivamente aos direitos relativos ao comércio e ao comerciante. Atualmente constitui uma disciplina ameaçada, pois, para ele, é edificada sobre noções fundamentais vetustas, e deveria ser revista: “(...) a expressão em si é imprópria; ela traduz de modo imperfeito, muito estreito, a realidade que se quer expressar. O que abrange, com efeito, a expressão Direito Comercial senão as regras que traduzem em termos jurídicos a atividade econômica, as operações que ela abarca, sua estrutura, seus mecanismos? Se esse Direito é ainda chamado comercial, o é como recordação da época longínqua na qual a

\footnotetext{
${ }^{93}$ VAn RYN, J. Principes de Droit Commercial. Bruxelas: Établissements Émile Bruylant, 1954.

${ }^{94}$ CorreiA, F. Lições de Direito Comercial. Coimbra: Universidade de Coimbra, 1965.
} 
atividade econômica se reduzia praticamente ao tráfico de mercadorias, ao negócio, ao comércio, no sentido mais estrito" $"$.

Continuamente, Jean van Ryn ilustra que se se reconhecer que o Direito Comercial é, de fato, o Direito das atividades econômicas, põe-se em evidência o exclusivo princípio de unidade que possibilita justificar o agrupamento em uma única disciplina destas diversas regras. Desse modo, o jurista citado acolhe a expressão Direito Econômico em substituição à "histórica e tradicional denominação que tantas ambigüidades, confusões e dificuldades têm gerado para a disciplina nos dias atuais", formulando um conceito mais amplo: "Nós poderemos dizer, de logo, que o domínio próprio do Direito Comercial é o conjunto de regras jurídicas relativas à atividade do homem aplicado à produção, à apropriação, à circulação e ao consumo das riquezas. O Comércio não é senão um dos elos da cadeia que constitui a atividade econômica global”. Assim, o domínio virtual do Direito Comercial seria determinado por seu objeto, e é o mesmo - como se observa - para Jean van Ryn, apenas em um plano diferente, da economia política. E confessa que "a definição de Economia Política, transposta para o plano jurídico, poderá, sem inconveniente, servirnos" 96 .

Julliot de la Morandière, no tocante às tendências de revisão da disciplina do Direito Comercial, as critica: "Em nossos dias, na opinião de certos autores, o direito comercial, longe de ceder às miragens da unidade do Direito privado, pretenderia constituir o núcleo de uma nova disciplina, montado sobre o Direito privado e o Direito público, o Direito Econômico, que teria por missão reger toda a vida econômica, Direito Comercial, Direito do Trabalho, da Propriedade Industrial, Direito Rural. É uma concepção. Outros desejariam que o Direito Econômico fosse somente um modo de colorir as regras usuais do Direito privado; outros, também, porque é o Direito da economia dirigida; outros, ainda, para quem é o Direito das empresas. Os agrupamentos de matérias jurídicas às quais convêm estas diversas teorias podem ser frutuosas, mas não constituem corpos de regras bem delimitadas para as quais se possa dizer que eles formem uma disciplina nova" ${ }^{\circ 7}$.

Em posição contrária, têm-se Julius Von Gierke, que em socorro da tradicional disciplina, confia que "nunca poderá o Direito Econômico pretender desalojar o Direito Comercial de suas posições" 98 .

\footnotetext{
${ }^{95}$ Van Ryn, J. Principes de Droit Commercial. Bruxelas: Établissements Émile Bruylant, 1954.

${ }^{96}$ Van Ryn, J. Principes de Droit Commercial. Bruxelas: Établissements Émile Bruylant, 1954.

${ }^{97}$ De LA MORAndière, J. Droit Commercial. Paris: Dalloz, 1965.

${ }^{98}$ Von GIERKE, J. Derecho Comercial y de la Navegácion. Buenos Aires: Ed. Argentina AS, 1957.
} 
O Direito Comercial tem um âmbito preciso e claro, que se identifica modernamente como o Direito das empresas mercantis. O Direito Econômico disciplinando o mercado de capitais, a atuação financeira do Estado no setor privado, os estímulos ao desenvolvimento econômico - tem, como se observa, princípios próprios e âmbito bem delineados. A questão não é identificar o Direito Comercial com o Direito Econômico, mas edificar o Direito Econômico como uma disciplina própria, sobretudo nos currículos dos cursos de Direito. Muito elucidativo é Arnoldo Wald quando discorre sobre o tema "Direito do Desenvolvimento", onde afiança debate em torno do Direito Econômico e do Direito Comercial: "O Direito Econômico se distingue, tanto do Direito Comercial como do Direito Administrativo", expõe o autor, "pela sua finalidade própria e pelo clima que pretende criar. Se, no Direito Comercial, as idéias básicas consistem na superior conciliação entre a celeridade dos negócios e as garantias do crédito, entre o formalismo e o automatismo das operações, entre a liberdade contratual e a segurança jurídica, o Direito Econômico visa dar à vida do país um aspecto ao mesmo tempo dinâmico e disciplinado" $" 99$.

\section{5) A empresa}

Da evolução e discussão das atividades ou atos comerciais surge a instituição chamada empresa. Nessa dissertação será elaborada breve conceituação e análise de sua natureza jurídica, bem como a conceituação na doutrina e legislação brasileira. Inicialmente, pode-se apontar o Código Civil italiano como um dos primeiros a adotar a teoria da empresa. Obviamente, à época, não foi formulado um conceito jurídico do que seria empresa, o que gerou largo esforço no sentido da formulação de um conceito jurídico. Nesse sentido, destaca-se a originalidade e facilidade didática exposta na teoria dos perfis da empresa elaborada por Alberto Asquini.

Ao observar o citado Código Civil italiano, Alberto Asquini defrontou-se com a inexistência de um conceito de empresa, e estudando o diploma legal chegou a conclusão de que haveria uma diversidade de perfis no conceito. Para ele "o conceito de empresa é o

${ }^{99}$ WALD, A. Direito do desenvolvimento. Revista dos Tribunais, São Paulo, RT 383/7, 1967. 
conceito de um fenômeno jurídico poliédrico, o qual tem sob o aspecto jurídico não um, mas diversos perfis em relação aos diversos elementos que ali concorrem"100.

Tal conceituação é considerada ultrapassada atualmente, no entanto, teve a felicidade de abordar vários conceitos proximamente relacionados ao conceito de empresa, os quais traduziriam o fenômeno da empresarialidade, na expressão cunhada por Waldirio Bulgarelli $^{101}$.

O primeiro perfil da empresa relacionado por Alberto Asquini foi o perfil subjetivo. Neste, a empresa se identificaria com o empresário, cuja acepção é dada pelo artigo 2.084 do Código Civil Italiano como sendo "quem exercita profissionalmente atividade econômica organizada com o fim da produção e da troca de bens ou serviços". Nesse caso, a empresa seria um indivíduo ${ }^{102}$.

O segundo dos perfis de Asquini é o funcional, identificando a empresa com a atividade empresarial. Esta teria aquela "particular força em movimento que é a atividade empresarial dirigida a um determinado escopo produtivo" ${ }^{103}$. Neste sentido, a empresa representaria um complexo de atos tendentes a organizar os fatores da produção para a distribuição ou produção de certos bens ou serviços.

Há ainda o perfil objetivo ou patrimonial que relacionaria a empresa com o conjunto de bens destinado ao exercício da atividade empresarial, distinto do patrimônio remanescente nas mãos da empresa, ou seja, a empresa seria um patrimônio afetado a uma finalidade específica ${ }^{104}$.

Por fim, tem-se o perfil corporativo, no qual a empresa seria a instituição que reúne o empresário e seus colaboradores, seria "aquela especial organização de pessoas que é formada pelo empresário e por seus prestadores de serviço, seus colaboradores (...) um núcleo social organizado em função de um fim econômico comum"105. Este perfil, efetivamente, não se fundamenta em dados, mas somente em ideologias populistas, demonstrando a influência da concepção fascista na elaboração do Código Civil italiano ${ }^{106}$.

Esse primeiro modo de entender o que é a empresa já está superado, dessa forma, não representa o estudo teórico da empresa em si, somente demonstra a imprecisão terminológica italiana. No entanto, excetuando o perfil corporativo, que reflete influências

\footnotetext{
${ }^{100}$ AsQUINI, A. Profili dell'impresa. Rivista di diritto commerciale, Vol. XLI - Parte I, p. 1-20, 1943, p. 1.

${ }^{101}$ Bulgarelli, W. Tratado de direito empresarial. 3. ed. São Paulo: Atlas, 1997, p. 99.

${ }_{102}$ AsQUINI, A. Profili dell'impresa. Rivista di diritto commerciale, Vol. XLI - Parte I, p. 1-20, 1943, p. 6.

${ }^{103}$ AsQUINI, A. Profili dell'impresa. Rivista di diritto commerciale, Vol. XLI - Parte I, p. 1-20, 1943, p. 9.

${ }^{104}$ AsQUINI, A. Profili dell'impresa. Rivista di diritto commerciale, Vol. XLI - Parte I, p. 1-20, 1943, p. 12.

105 ASQUINI, A. Profili dell'impresa. Rivista di diritto commerciale, Vol. XLI - Parte I, p. 1-20, 1943, p. $16 / 17$.
} 
de momento político, os demais perfis demonstram realidades muito próximas entre si e bastante importantes na teoria da empresa, a empresa em si, o empresário e o estabelecimento.

Efetuado esse primeiro estudo e relevando-se eventuais imprecisões terminológicas, que não são o escopo desse estudo, tem-se de imediato que empresa é a "atividade econômica organizada de produção ou circulação de bens ou serviços", ou seja, relacionase ao perfil funcional da teoria de Alberto Asquini ${ }^{107}$.

Segundo Tullio Ascarelli, trata-se de atividade, isto é, do conjunto de atos destinados a um fim comum, que ordena os fatores da produção, para produzir ou fazer circular bens ou serviços. Nesse sentido, um ato isolado não é suficiente, é necessária uma sequência de atos dirigidos a uma mesma finalidade, para configurar a empresa ${ }^{108}$.

Segundo Vedove, a economicidade da atividade exige que a mesma seja capaz de criar novas utilidades, novas riquezas, afastando-se as atividades de mero gozo ${ }^{109}$. Nessa criação de novas riquezas, pode-se transformar matéria-prima (indústria), como também pode haver a interposição na circulação de bens (comércio em sentido estrito), aumentando o valor dos mesmos ${ }^{110}$.

Ademais, tal atividade deve ser direcionada ao mercado, ou seja, deve ser destinada à completa satisfação de necessidades alheias, sob pena de não configurar uma empresa. Dessa forma, não é empresa a atividade daquele que cultiva ou fabrica para o próprio consumo, vale dizer, "o titular da atividade deve ser diverso do destinatário último do produto"$^{111}$.

Do mesmo modo, é item característico da empresa a organização dos fatores da produção, pois a finalidade produtiva da empresa pressupõe atos coordenados e programados para se atingir tal objetivo. Essa organização pode assumir os formatos mais variados de acordo com as necessidades da atividade, congregando "seja a atividade que se exercita organizando o trabalho alheio, seja aquela que se exercita organizando um

\footnotetext{
${ }^{106}$ Coelho, F. U. Curso de direito comercial. São Paulo: Saraiva, vol. 1, 2005, p. 19.

${ }^{107}$ CoElho, F. U. Curso de direito comercial. São Paulo: Saraiva, vol. 1, 2005, p. 19.

108 Ascarelli, T. Corso di diritto commerciale: introduzione e teoria dell'impresa. $3^{\mathrm{a}}$ ed. Milano: Giuffrè, 1962, p. 146.

${ }^{109}$ Vedove, G. Dalle. Nozioni di diritto d'impresa. Padova: CEDAM, 2000, p. 14; Ferrara Júnior, F.; CORSI, F. Gli imprenditori e le societá. 11 ed. Milano: Giuffrè, 1999, p. 33.

${ }^{110}$ Ascarelli, T. Corso di diritto commerciale: introduzione e teoria dell'impresa. $3^{\mathrm{a}}$ ed. Milano: Giuffrè, 1962, p. 162.

${ }^{111}$ Ascarelli, T. Corso di diritto commerciale: introduzione e teoria dell'impresa. $3^{\mathrm{a}}$ ed. Milano: Giuffrè, 1962, p. 163.
} 
complexo de bens ou mais genericamente de capitais, ou como para o mais advém, aquela que se atua coordenando uns e outros" ${ }^{112}$.

Em função da necessidade dessa organização, deve ser explicitado ainda que as atividades relativas a profissões intelectuais, científicas, artísticas e literárias não são exercidas por empresários, a menos que constitua elemento da empresa, no Código Civil brasileiro tal situação é explícita em seu artigo 966, parágrafo único ${ }^{113}$. Essa constatação se deve em função de que em tais atividades prevalece a natureza individual e intelectual sobre a organização, a qual é reduzida a um nível hierárquico inferior ${ }^{114}$. Assim, é a relevância dessa organização que distingue a atividade empresarial de outras atividades econômicas.

Por fim, a empresa deve abarcar a produção ou circulação de bens ou serviços para o mercado. Na produção tem-se a transformação de matéria-prima e na circulação a intermediação na negociação de bens. No que diz respeito aos serviços, deve-se abarcar toda "atividade em favor de terceiros apta a satisfazer uma necessidade qualquer, desde que não consistente na simples troca de bens", ou seja, eles não podem ser objeto de detenção, mas de fruição ${ }^{115}$.

\subsection{1) Natureza jurídica da empresa}

Uma vez explícito um conceito inicial de empresa, esta compreendida como a atividade econômica organizada, tem-se que tal termo não se embaralha nem com o sujeito exercente da atividade, nem com o complexo de bens por meio dos quais se exerce a atividade, que representam outras situações distintas. Waldirio Bulgarelli, ao analisar a distinção entre essas três realidades, demonstra um conceito analítico descritivo de empresa, no seguinte formato: "Atividade econômica organizada de produção e circulação

\footnotetext{
112 Vedove, G. Dalle. Nozioni di diritto d'impresa. Padova: CEDAM, 2000, p. 14; Ferrara Júnior, F.; CORSI, F. Gli imprenditori e le societá. 11 ed. Milano: Giuffrè, 1999, p. 39.

${ }^{113}$ Art. 966. "Considera-se empresário quem exerce profissionalmente atividade econômica organizada para a produção ou a circulação de bens ou de serviços. Parágrafo único. Não se considera empresário quem exerce profissão intelectual, de natureza científica, literária ou artística, ainda com o concurso de auxiliares ou colaboradores, salvo se o exercício da profissão constituir elemento de empresa". BrasiL. Código Civil. Brasília. 1988. Disponível em <http://www.planalto.gov.br/ccivil_03/Leis/2002/L10406.htm>. Acesso em: 26 nov. 2010.

${ }^{114}$ DE CUPIS, A. Instituzioni di diritto privato. Milano: Giuffrè, 1978, v. 3, p. 134.

${ }^{115}$ Vedove, G. Dalle. Nozioni di diritto d'impresa. Padova: CEDAM, 2000, p. 14; Ferrara Júnior, F.; CORSI, F. Gli imprenditori e le societá. 11 ed. Milano: Giuffrè, 1999, p. 13-14.
} 
de bens e serviços para o mercado, exercida pelo empresário, em caráter profissional, através de um complexo de bens"116. Nesse conceito estão expostos as três idéias essenciais sem confusões, quais sejam, a empresa, o empresário e o estabelecimento.

A empresa não é detentora de personalidade jurídica, e nem pode possuí-la e sendo que conseqüentemente não pode ser entendida como sujeito de direito, uma vez que ela é a atividade econômica que se contrapõe ao titular dela, isto é, ao exercente daquela atividade $^{117}$. O titular da empresa é o que se denomina de empresário.

Aqueles que se afastaram da noção de sujeito de direito, Rubens Requião, Marcelo Bertoldi e José Edwaldo Tavares Borba qualificam a empresa como objeto de direito ${ }^{118}$. Segundo Fábio Coelho, talvez essa qualificação não seja a mais correta uma vez que não se pode conceber uma atividade como objeto de direito, consequentemente não se pode vislumbrar a empresa como matéria dos direitos subjetivos, principalmente dos Direitos Reais, vale dizer, a atividade de per si não pode ser transferida ${ }^{119}$.

Assim, torna-se mais interessante a empresa ser enquadrada como um terceiro gênero, uma nova categoria jurídica, pois não se trata nem de sujeito nem de objeto de direito $^{120}$, adequando-se justamente à noção de fato jurídico em sentido amplo. Tal acepção se mostra mais correta que a de ato jurídico, pois se fala da atividade, do conjunto de atos, e não de cada ato isolado, que poderia ser enquadrado na condição de ato jurídico.

\subsection{2) Conceito de empresa no Direito brasileiro}

As mesmas dificuldades e complexidades constantes no Direito estrangeiro estão refletidas nos estudos nacionais. O Regulamento $\mathrm{n}^{\mathrm{o}} 737$, de 1850 , no art. 19, ao elencar os

\footnotetext{
${ }^{116}$ Bulgarelli, W. Tratado de direito empresarial. 3. ed. São Paulo: Atlas, 1997, p. 100.

${ }^{117}$ MessineO, F. Manuale di diritto civile e commerciale. Milano: Giuffrè, 1957, v. 1, p. 337; SANTORO PASSARElli, F. Saggi di diritto civile. Napóli: Jovene, 1961, v. 2, p. 979; NEGRÃO, R. Manual de direito comercial. Campinas: Bookseller, 1999; GOMES, O. Introdução ao direito civil. Atualização e notas de Humberto Theodoro Junior. 15 ed. Rio de Janeiro: Forense, 2000, p. 205.

${ }^{118}$ Requião, R. Curso de Direito Comercial. 25 ed. São Paulo: Saraiva, v. 1, 2003, p. 60; Bertoldi, M. M. Curso avançado de direito comercial. São Paulo: RT, 2001, p. 56; BORBA, J. E. T. Direito societário, 5 ed. Rio de Janeiro: Renovar, 1999, p.27.

${ }^{119}$ Ascarelli, T. Corso di diritto commerciale: introduzione e teoria dell'impresa. $3^{\mathrm{a}}$ ed. Milano: Giuffrè, 1962, p. 156. Coelho, F. U. Curso de direito comercial. 4 ed. São Paulo: Saraiva, 2005, v. 1, p. 27.

${ }^{120}$ Bulgarelli, W. Tratado de direito empresarial. 3. ed. São Paulo: Atlas, 1997, p. 132; MessineO, F. Manuale di diritto civile e commerciale. Milano: Giuffrè, 1957, v. 1, p. 336, NegRão, R. Manual de direito comercial. Campinas: Bookseller, 1999, p. 76.
} 
atos de comércio, incluiu as empresas, dando início, no campo do Direito Comercial pátrio, aos trabalhos de sua conceituação ${ }^{121}$.

É possível observar que o legislador, ao incluir as empresas entre os atos, como figurativas ou componentes da mercancia, usou do termo, tal como desenhado no Direito francês, como repetição de atos praticados a título profissional. Nesse sentido, é conhecida a análise de Inglêz de Souza: "Por empresa devemos entender uma repetição de atos, uma organização de serviços, em que se explore o trabalho alheio, material ou intelectual. A intromissão se dá, aqui, entre o produtor do trabalho e o consumidor do resultado desse trabalho, com intuito de lucro"122. Esse estreito conceito de "empresa" obviamente não serve mais à doutrina moderna.

J. X. Carvalho de Mendonça, em outro sentido, conceituou a empresa como "a organização técnico-econômica que se propõe produzir a combinação dos diversos elementos, natureza, trabalho e capital, bens ou serviços destinados à troca (venda), com esperança de realização de lucros, correndo riscos por conta do empresário, isto é, daquele que reúne, coordena e dirige esses elementos sob sua responsabilidade" ${ }^{, 123}$.

Preocupando-se em antever eventuais críticas ao conceito apresentado, claramente sobreposto ao conceito econômico, J. X. Carvalho de Mendonça adiantou-se, declarando que, de fato, "o conceito econômico é o mesmo do jurídico, em que pese a alguns escritores que os distinguem sem fundamento". Demonstra: "O Direito Comercial considera a empresa que se apresenta com caráter mercantil. Desse modo, o empresário, organizando e dirigindo a empresa, realiza, como todo comerciante, uma função de mediação, intrometendo-se entre a massa de energia produtora (máquinas, operários, capitais) e os que consomem, concorrendo destarte para a circulação de riqueza"124. São, dessa forma, pressupostos da empresa os seguintes pontos: a) uma série de negócios do mesmo gênero de caráter mercantil; b) o emprego de trabalho ou capital, ou de ambos combinados; c) a assunção do risco próprio da organização.

${ }^{121}$ Art. 19. "Considera-se mercancia: $§ 1^{\circ}$ A compra e venda ou troca de effeitos moveis ou semoventes para os vender por grosso ou a retalho, na mesma especie ou manufacturados, ou para alugar o seu uso. $\S 2^{\circ}$ As operações de cambio, banco e corretagem. $\S 3^{\circ}$ As emprezas de fabricas; de com missões ; de depositos ; de expedição, consignação e transporte de mercadorias; de espectaculos publicos. $\S 4 .^{\circ}$ Os seguros, fretamentos, risco, e quaesquer contratos relativos ao cornmercio maritimo. § 5. "A armação e expediç1to de navios".

BRASIL. Regulamento 737. Rio de Janeiro. $1850 . \quad$ Disponível em <http://www.jusbrasil.com.br/legislacao/103248/decreto-737-50>. Acesso em: 26 nov. 2010.

${ }^{122}$ De SouZA, I. Preleções de Direito Comercial. 5 ed. Rio de Janeiro: Livraria Jacinto, 1935.

123 Carvalho de Mendonça, J. X. Tratado de direito comercial brasileiro. Atualizado por Ricardo Negrão. Campinas: Bookseller, 2000.

124 Carvalho de MendonçA, J. X. Tratado de direito comercial brasileiro. Atualizado por Ricardo Negrão. Campinas: Bookseller, 2000. 
Waldemar Ferreira examina vários aspectos do assunto, tal como Sylvio Marcondes Machado, que o estudou pormenorizadamente no Direito comparado e no Direito nacional, na sua monografia de concurso Limitação da Responsabilidade de Comerciante Individual. Em suas observações finais tem-se que; "É de concluir-se pela inexistência de componentes jurídicos que, combinados aos dados econômicos, formem um conceito genérico de empresa; ou, considerada a constância do substrato econômico, pela inexistência de um conceito de empresa como categoria jurídica"125.

Tamanho foi o interesse dos juristas nacionais na pesquisa e formulação do conceito de empresa que os apontamentos sobre a matéria são os mais diversos. Segundo Requião, o Professor Francisco Campos, em palestra no II Congresso Jurídico Nacional, apontou que na economia brasileira, à época constituída de pequenas empresas, em que predomina a presença da pessoa do empresário, não se vê figura abstrata da empresa, "a organização técnica, a despersonalização da atividade econômica, que é um elemento fundamental ou essencial ao conceito de empresa". Nega o jurista, dadas as condições do subdesenvolvimento econômico, maior interesse no equacionamento do problema, uma vez que "seria, evidentemente, deformar a realidade, principalmente nos países em desenvolvimento como o nosso, querer calcar sobre as atividades individuais, de caráter rudimentar e sem nenhuma organização, o conceito de empresa". Observa, porém, que "com a tendência de predominarem na vida econômica as grandes organizações despersonalizadas, devemos forjar outros conceitos em substituição àqueles que vigoram na época individualista e liberal do Direito Comercial". Assim, o conceito de empresa, segundo ele, "é destinado a ter um grande futuro"126.

Pode-se observar que o jurista nacional, à época, coloca-se em posição empírica, solidarizando-se apenas com os aspectos práticos, relegando o prisma científico da análise da empresa. O estudo da matéria era incoercível no Brasil, malgrado a fragilidade daquela organização empresarial.

A idéia de empresa, como categoria primordial do Direito Comercial, já se impôs nos estudos da disciplina jurídica e nos pronunciamentos jurisprudenciais dos tribunais brasileiros. O problema a estudar não é o de poderio econômico da empresa e sua predominância no campo econômico, mas sim a sua definição como categoria básica, como o ponto de partida do Direito Mercantil. Segundo Rubens Requião, “constituem, de

\footnotetext{
${ }^{125}$ MACHADO, S. M. Limitação da Responsabilidade de Comerciante Individual. São Paulo: Revista dos Tribunais, 1956.

${ }^{126}$ REQUiÃo, R. Curso de direito comercial. 25 ed. São Paulo: Saraiva, 2003, v. 1, p. 57.
} 
fato, seu estudo e sua pesquisa um imperativo das transformações que a sociedade tem sofrido, com a correspondente evolução do direito, com o aperfeiçoamento de suas instituições"127.

Sem ou com a conceituação devida, a empresa tem sido objeto do Direito positivo, formulando critérios e noções para deles se valer em seus propósitos. Por exemplo, a Lei ${ }^{\circ}$ 4.137, de 10 de setembro de 1962 (hoje revogada e substituída pela Lei $\mathrm{n}^{\circ}$ 8.884, de 11 de junho de 1994, art. 92), que coibia o abuso do poder econômico, viu-se na contingência de formular um conceito legal, como base na repressão que objetiva. No art. $6^{\circ}$, declarava que "considera-se a empresa toda organização de natureza civil ou mercantil destinada à exploração por pessoa física ou jurídica de qualquer atividade com fins lucrativos" ${ }^{\text {"128. }}$.

Não teve o legislador, receio de definir a empresa, em sentido objetivo. Já a comissão que elaborou o Projeto de Código Civil se deixou dominar pela vertente dos italianos de 1942 e evitou definir a empresa. Absorveu o mesmo critério do Código italiano, conceituando apenas o empresário. E empresário, para o Projeto e agora também pelo Código Civil de 2002, art. 966, é "quem exerce profissionalmente atividade econômica organizada para a produção ou a circulação de bens ou de serviços"129.

\section{6) A empresa como uma abstração}

Segundo Rubens Requião, “a figuração que o leigo faz de empresa é no sentido objetivo de sua materialização" ${ }^{130}$. Nesse sentido, explica-se a confusão entre empresa e estabelecimento comercial (art. 1.142 do Código Civil) e, no mesmo sentido, entre empresa e sociedade. É normal o empresário referir-se ao seu estabelecimento comercial, ou à sociedade de que é titular ou sócio maior, como "a minha empresa". Os conceitos, no entanto, são intransigíveis.

É necessário compreender que a empresa, como ente jurídico, é uma abstração. Em um primeiro momento, parece absurda e incompreensível tal afirmação, dado aquele condicionamento de que a empresa é uma entidade material e visível. Antonio Brunetti

\footnotetext{
${ }^{127}$ REQUIÃo, R. Curso de direito comercial. 25 ed. São Paulo: Saraiva, 2003, v. 1, p. 58.

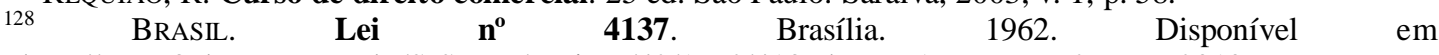
<http://www3.dataprev.gov.br/SISLEX/paginas/42/1962/4137.htm>. Acesso em: 26 nov. 2010.

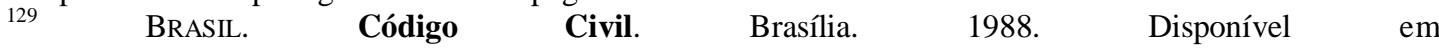
<http://www.planalto.gov.br/ccivil_03/Leis/2002/L10406.htm>. Acesso em: 26 nov. 2010.
} 
chegou à conclusão da abstratividade da empresa, analisando que "a empresa, se do lado político-econômico é uma realidade, do jurídico é un'astrazione, porque, reconhecendo-se como organização de trabalho formada das pessoas e dos bens componentes da azienda, a relação entre a pessoa e os meios de exercício não pode conduzir senão a uma entidade abstrata, devendo-se na verdade ligar à pessoa do titular, isto é, ao empresário"131 .

Observa-se que uma constante da doutrina a respeito da conceituação da empresa é mantê-la como o exercício de uma atividade (art. 966 do Código Civil). É da ação provocada (elemento abstrato) do empresário em exercitar a atividade econômica que surge a empresa. Dalmartello expõe claramente o tema, ressaltando que a "empresa é caracterizada pelo exercício da organização. Se todos os seus elementos estiverem organizados, mas não se efetivar o exercício dessa organização, não se pode falar em empresa" ${ }^{\prime 132}$.

Dessa forma, o empresário ordena a sua atividade, organizando os seus bens (capital) com o trabalho contratado de outrem, surgindo assim a organização. Essa organização, em si, compõe somente um complexo de bens e um conjunto de pessoal inativo. Assim, esses elementos - bens e pessoal - não se juntam por si; é necessário que sobre eles, corretamente organizados, atue o empresário, potencializando a organização, imprimindo-lhe atividade que levará à produção. Tanto o capital investido do empresário como o pessoal que irá laborar nada mais são isoladamente do que bens e pessoas. A empresa somente surge quando se inicia a atividade sob a orientação do empresário.

Dessa análise observa-se a clara idéia de que a empresa é essa organização dos fatores da produção exercida, colocada a funcionar, pelo empresário. Ao evaporar o exercício da atividade organizada do empresário, desaparece, ipso facto, a empresa. Nesse sentido, o porquê do conceito de empresa se firmar na idéia de que é ela o exercício de atividade produtiva. Conseqüentemente, do exercício de uma atividade não se tem senão uma idéia abstrata.

Essa abstração será de suma importância na tonificação do poderio empresarial. O crescente aumento dos ganhos e volumes produzidos demonstra cada vez mais que, em sendo uma abstração, o modelo de gestão de muitas empresas está diluído e tonificado no vértice espaço e tempo. Dessa forma, para que a continuidade da empresa se dê de forma organizada, a observância de regras e princípios além de sua jurisdição se faz algo

\footnotetext{
${ }^{130}$ ReQuião, R. Curso de direito comercial. 25 ed. São Paulo: Saraiva, 2003, v. 1, p. 59.

${ }^{131}$ Brunetti, A. Trattato Del Diritto delle Società. Milão: Dott. A. Giuffrè Ed., 1948.

${ }^{132}$ Dalmartello, A. Contratti delle Imprense Commerciali. Padova: Cedam, 1939.
} 
moderno e importante, principalmente se atua fora dos domínios de um Estado, como poderá ser observado no item seguinte.

\section{7) Empresa Transnacional}

No exercício de atividades além das fronteiras do Estado de origem, surge a empresa transnacional, assim qualificada, uma vez que passa a integrar o restrito rol de entidades de interesse para o Direito Internacional, sem esquivar-se de submeter-se às legislações das nações em que, inicialmente, foi incorporada e às daqueles nos quais passa a operar ${ }^{133}$.

As empresas transnacionais (Transnational Corporations - TNCs) têm sido objeto de vários estudos, nos últimos anos, tendo em vista sua crescente importância, mas isso não torna fácil chegar-se a uma conceituação definitiva, em virtude de sua larga variedade.

Segundo Fábio Konder Comparato, nos últimos anos, tem-se observado a adoção de um esquema retilíneo, no qual "a vinculação entre as unidades empresariais já não se faz em termos de participação societária no capital, mas adota antes uma rede de contratos estáveis. A grande novidade, sob o aspecto jurídico, é a de que esses grupos societários conservam, não obstante o abandono da técnica de participação acionária, uma estrutura de controle societário externo, sob a forma contratual (Gleichordnungskonzern), como ocorre nos consórcios de empresas. Na rede grupal, a sociedade controladora, denominada broker, assume exclusivamente as funções de governo de um conjunto de outras empresas fornecedoras de componentes ou matérias-primas, fabricadoras de produtos acabados, pesquisadoras de novos produtos e novos mercados, ou distribuidoras em diferentes mercados nacionais" $" 134$.

Segundo José Cretella Neto, a dificuldade é ainda maior para se "conceituar, sob a perspectiva jurídica, a estrutura, as formas de controle e as atividades quando se trata de empresas transnacionais, pois as relações jurídicas se entrelaçam não apenas no que diz

133 Cretella Neto, J. Empresa transnacional e direito internacional: exame do tema à luz da globalização. Rio de Janeiro: Forense, 2006, p. 17.

${ }_{134}$ Comparato, F. K. Estado, Empresa e Função Social. Revista dos Tribunais, São Paulo, RT 732/38, 1985. 
respeito ao conjunto de empresas envolvidas, mas com relação às diversas ordens normativas, de diferentes Estados, e também entre estas e o Direito Internacional"135.

São inúmeras as conceituação doutrinárias, bem como as elaboradas por institutos e organizações internacionais, sendo assim, para sintetizar os vários conceitos utiliza-se nessa dissertação a indicação exposta por José Cretella Neto de que a empresa transnacional deve ser entendida como: "a sociedade mercantil, cuja matriz é constituída segundo as leis de determinado Estado, na qual a propriedade é distinta da gestão, que exerce controle, acionário ou contratual, sobre uma ou mais organizações, todas atuando de forma concertada, sendo a finalidade de lucro perseguida mediante atividade fabril e/ou comercial em dois ou mais países, adotando estratégia de negócios centralmente elaborada e supervisionada, voltada para a otimização das oportunidades oferecidas pelos respectivos mercados internos"136.

Tal estratégia de negócios pode conjugar, num primeiro momento, apenas na importação de bens e/ou serviços para serem distribuídos em mercados de interesse, diverso dos do país de origem, até a construção de unidades fabris destinadas a suprir os mercados onde se instalam, bem como se utilizar das facilidades aí concebidas para exportar para outros mercados. Também pode consistir na criação de filiais a $100 \%$ (ou quase), na constituição de joint-ventures com empresas regionais, ou na penetração de mercados mediante contratos de franchising. Observa-se, ademais, que somente o critério da multinacionalidade dos acionistas não pode quadrar de base para conceituar a empresa transnacional.

As empresas transnacionais são atualmente consideradas, por alguns juristas, como sujeitos auxiliares do Direito Internacional Público, atuando, por sua força econômica e pelo poder político internacional de fato, no organograma das organizações oficiais e impondo-se, com maior relevância do que a grande maioria dos Estados, como agentes de responsabilidade no processo internacional de decisões políticas, sociais e econômicas ${ }^{137}$. Outros estudiosos acreditam que, sob o olhar estritamente jurídico-positivo, "não existe a empresa transnacional, razão pela qual a descrição que dela fazem os economistas, é útil para sua conceituação" ${ }^{\text {"138 }}$. Essa posição utiliza-se da justificativa de que o conceito se

135 Cretella Neto, J. Empresa transnacional e direito internacional: exame do tema à luz da globalização. Rio de Janeiro: Forense, 2006, p. 18.

${ }_{136}$ CRETElla Neto, J. Empresa transnacional e direito internacional: exame do tema à luz da globalização. Rio de Janeiro: Forense, 2006, p. 27.

137 CRetella Neto, J. Empresa transnacional e direito internacional: exame do tema à luz da globalização. Rio de Janeiro: Forense, 2006, p. 28.

${ }^{138}$ B APTISTA, L. O. Empresa Transnacional e Direito. São Paulo: Revista dos Tribunais, 1987, p. 18. 
aproxima do de grupo de sociedades, mas com o incremento de que é um grupo constituído por sociedades baseadas em Estados diferentes, constituídos por normas diversas, cada qual com certa autonomia, agindo por sua conta, mas em benefício do conjunto.

Nessa linha de entendimento, ao aceitar a definição de empresa transnacional como "um complexo de empresas interligadas entre si, subordinadas a um controle central unificado e obedecendo a uma estratégia global", não se está somente a diminuir o conceito, mas a simplificá-lo a uma estrutura funcional, excluindo-se das considerações as importantes implicações da referida "estrutura retilínea", na qual o controle pode ocorrer tanto pela via da participação acionária quanto pela contratual. Todavia, ocorre que as “empresas nacionais", no quadro da organização transnacional, são criadas e funcionam de forma concertada e sinérgica, ou seja, o poderio econômico e político de que pode se utilizar o grupo é muito maior do que a soma das forças individuais.

Não deixando de clamar para o fato de que "o fenômeno empresa multinacional é de recente data, não tendo sido objeto, ainda, de caracterização precisa", expõe José Carlos de Magalhães classificação que leva em conta importante singularidade, que distingue a transnacional de outros tipos comuns de empresa, e que consiste em não se ater à operação na área internacional, mas "a integração de toda rede de subsidiárias em um complexo que a transforma em uma unidade econômica, sujeita a um controle central, voltado para o mercado mundial"139.

Destarte a análise de estudiosos que negam a existência, no plano jurídico-positivo, da empresa transnacional, estas são reconhecidas por vários, como os "mais formidáveis rivais, modernamente, do Estado, não se podendo deixar de reconhecer, todavia, que o poder dos grupos, embora baseado em força social autônoma, tende a subordinar-se ao poder da sociedade global, representado, hoje, pelo Estado" ${ }^{\text {140 }}$. Todavia, cada grupo possui o seu sistema de interações, refletindo-se num determinado conjunto de normas cuja coexistência atesta o pluralismo jurídico ${ }^{141}$. Miguel Reale ao reconhecer a graduação de positividade e ao dar razão aos pluralistas, atesta "a existência de uma multiplicidade de ordenamentos jurídicos internos em cada país, mas por outro lado (estabeleço) que entre eles existe uma gradação de positividade, correlacionada a uma gradação de poder, ambos

\footnotetext{
${ }^{139}$ Magalhães, J. C. de. Empresa Multinacional: Descrição Analítica de um Fenômeno Contemporâneo, Revista de Legislação do Trabalho, vol. 39, 1975, pp. 493-509.

${ }^{140}$ Duverger, Maurice. Sociologie de la Politique. Paris: PUF, 1973, p. 33.

141 IngBeR, L.. Le Pluralisme Juridique dans l'Oeuvre des Philosophes du Droit, In: Le Pluralisme Juridique, Bruxelas: Universidade de Bruxelas, 1972, p. 83.
} 
os fenômenos se implicando em uma relação dialética de polaridade" ${ }^{\text {"142 }}$. Assim, são exatamente as empresas transnacionais as organizações que com mais desenvoltura se utilizam dessa multiplicidade de legislações, e se beneficiam do melhor tratamento conferido por um ou por outro país a suas subsidiárias e seus investimentos.

Ainda que seja difícil conseguir caracterizar juridicamente a empresa transnacional, não pode ser tida como obstáculo instransponível, pois interessa ao menos a cinco áreas do Direito, e os teóricos especializados não consentem de incorporar avanços doutrinários ao estudar sobre as TNCs e a maneira pela qual interatuam e afetam os seguintes campos: Direito Tributário, Direito do Trabalho, Direito Comercial (ou Direito Empresarial), Direito Econômico e Direito Internacional.

No âmbito ambiental, o controle tanto nacional quanto internacional, deve ser, muitas vezes, severo, pois já há algumas décadas se noticia que rejeitos tóxicos têm sido transacionados por empresas (ou seus Estados de origem) com países menos desenvolvidos, que os recebem e armazenam, muitas vezes em condições que colocam em risco a saúde das populações, em troca de pagamentos ou de financiamentos a projetos de interesse para esses países, em colidente contrariedade aos princípios e às normas determinadas nos tratados sobre o meio ambiente. Resta evidente que, nessas situações, a debilidade econômica dos Estados menos desenvolvidos os levam a aceitar condições de permuta desfavoráveis, a pretexto de superar as graves crises econômicas de que sofrem, seja de comércio exterior, de cunho financeiro e fiscal, ou as relativas ao câmbio, amenizando o destempero econômico com a obtenção de recursos em moeda estrangeira.

Assim, o Direito Internacional deve ser aplicado à empresa transnacional, a TNC deve conformar-se às normas do Direito Internacional e, em não fazendo, sofrer as sanções cabíveis no plano internacional; e, conseqüentemente, à TNC deve ser permitida a inovação de determinada norma de Direito Internacional como padrão de conduta legal dos demais sujeitos do DIP, como os Estados e as Organizações Internacionais.

Com os apontamentos expostos neste segundo capitulo da dissertação e as possíveis definições sobre empresa e especialmente empresa transnacional, encerra-se o momento em que se buscam recursos conceituais para o estudo. No próximo capítulo serão analisados, com maior sentindo à conclusão da pesquisa, a inter-relação entre empresa e meio ambiente sob a análise jurídica e perspectiva dos melhores métodos de desenvolvimento.

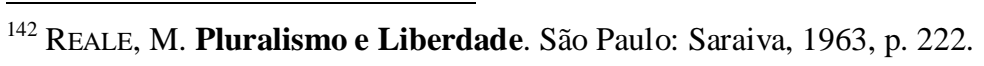


Já resta evidente que a atuação de empresas transnacionais será o foco da análise de absorção de normas e princípios do Direito Internacional do Meio Ambiente, por razões puras: a sua internacionalidade; relevância econômica; potencial de dano ao meio ambiente; por ser agregadora indireta de outras empresas, especialmente as nacionais; bem como pela proximidade direta e indireta com indivíduos que nela trabalham (funcionários), acionistas (shareholders) ou terceiros interessados (stakeholders), que congregam um grande universo da sociedade. 


\title{
III - DESENVOLVIMENTO SUSTENTÁVEL
}

\author{
3.1) As externalidades
}

As atividades econômicas existentes, em maior ou menor grau, possuem um contexto necessariamente social. Esse contexto é gerado pela atividade do empresário e pode afetar a sociedade circunscrita àquela empresa de várias formas. Algumas empresas poluem o ar, água ou solo, outras esgotam fontes de matéria-prima, demandam projetos grandiosos de infra-estrutura (portos, aeroportos, ferrovias) e em alguns casos até o deslocamento de populações. Dessa forma, pode-se apontar que essas empresas criam custos sociais de grande monta, que poderão ou não ser compensados com os benefícios que a mesma atividade econômica proporciona para a sociedade, exemplificativamente, os novos empregos, diretos e indiretos, novos produtos e oportunidades, entre outros. Ou seja, a matriz compensatória entre custos e benefícios nem sempre possui um ponto ótimo ou razoável $^{143}$.

Em várias situações, os agentes econômicos podem usufruir mais benefícios que os custos dispensados; outros, de forma inversa, ocasionam o que tecnicamente se denomina externalidade ou deseconomia externa. É de se notar que esses agentes podem ser um amplo conjunto de pessoas, que agregam não somente empresários, que organizam e dirigem atividades econômicas de produção ou circulação de bens ou serviços, mas também todas as pessoas com uma função na economia de uma sociedade. Essa conceituação, portanto, também envolve consumidores, trabalhadores, o próprio Estado e demais interessados ou atingidos.

Segundo Fábio Ulhoa Coelho, externalidade é entendida "como todo efeito produzido por um agente econômico que repercute positiva ou negativamente sobre a atividade econômica, renda ou bem-estar de outro agente econômico, sem a correspondente compensação. Nenhum pedestre morador de uma metrópole, por exemplo, é compensado por respirar o ar contaminado pelos poluentes produzidos por veículos das empresas de transporte coletivo, mas também não é obrigado a remunerar o aumento de espaço livre nas calçadas propiciado pelo serviço dessas mesmas empresas. Tanto a

${ }^{143}$ Coelho, F. U. Curso de direito comercial. São Paulo: Saraiva, vol. 1, 2005, p. 33. 
poluição do ar como o aumento do espaço livre nas calçadas são, para o pedestre, externalidades da prestação do serviço de transporte coletivo, não ressarcidas de parte a parte" ${ }^{, 144}$.

Resumidamente, externalidade pode ser considerada como qualquer efeito, negativo ou positivo, que um indivíduo produz sobre a atividade econômica, a renda ou o bem-estar de um ou mais, sem compensar devidamente os prejuízos que causa nem ser compensado pelos benefícios que eventualmente trouxer. Pode-se apontar duas possíveis situações jurídicas advindas da noção de externalidade: a maneira de se distinguirem as relevantes das irrelevantes e a opção de meios para a compensação das externalidades relevantes.

De acordo com Mercado Pacheco, o aspecto inicial que trata do aproveitamento desse conceito econômico no campo do Direito, a separação entre externalidade relevante e irrelevante, estaria unido à determinação da ilicitude ou licitude da atividade ${ }^{145}$. Todavia, é de se apontar que a importância da externalidade está diretamente relacionada com mudanças comportamentais e evolução de valores, não necessariamente reproduzidas em normas proibitivas de atividades econômicas. Nesse sentido, pode-se observar que apenas recentemente a agressão de empresas ao meio ambiente converteu-se em uma externalidade relevante. No Brasil, a primeira lei a tratar sobre controle de poluição é de $1967^{146}$. No entanto, o Direito Ambiental não tem se utilizado de mecanismos que defrontem essa transformação com a interdição das atividades poluidoras, e sim por meios mais ou menos eficientes de controle de produção de poluentes. Obviamente, é trabalho por demais hercúleo pretender a compensação de todas as deseconomias externas, tendo em vista inclusive que as compensações são, por si só, geradoras também de novas externalidades: ou seja, o Estado, ao normatizar regras de Direito Ambiental às empresas, gera, como agente econômico no conceito amplo aqui delineado, uma externalidade para o empresário e conseqüentemente seus funcionários, sócios, acionistas, fornecedores, entre outros.

Não é possível eliminar, quando se realiza uma atividade econômica, uma determinada produção de efeitos negativos ou positivos não compensáveis. Esse pequeno descompasso pode ser considerado como uma externalidade irrelevante, uma vez que os efeitos advindos da empresa não merecem os contornos do Direito. Podem ser considerados como fatos não jurídicos, ou seja, ignorados pelo ordenamento jurídico, tendo

\footnotetext{
${ }^{144}$ Coelho, F. U. Curso de direito comercial. São Paulo: Saraiva, vol. 1, 2005, p. 33.

${ }^{145}$ PACHECO, P. M. El analisis econômico del derecho - uma reconstrucción teórica. Madrid: Centro de Estúdios Constitucionales, 1994, p. 136.
} 
em vista a irrelevância dos interesses atingidos, segundo ponderações de valor variáveis historicamente.

A segunda situação jurídica advinda do conceito de externalidade volta-se à definição dos meios de compensação entre os atores econômicos expostos a tais efeitos (empresa, sociedade, entre outros). Em um entendimento econômico, esta situação concerne ao processo de "internalização das externalidades". No momento em que é conferida relevância a determinados efeitos produzidos por um fato econômico, por exemplo, uma empresa que causa danos ambientais e gera empregos, é necessário discutir como desenvolver sua compensação. Nesse sentido, é importante afastar quaisquer radicalismos, uma vez que é preciso imputar deveres ao empresário pelos efeitos considerados negativos e reconhecer direitos em relação aos reputados positivos. Conceitualmente, em havendo a compensação de uma externalidade ela deixa per se de existir, portanto, internalizada, não gerando efeitos para terceiros. Internalizar as externalidades para desambiguar a relação custos-benefícios sociais é, juridicamente, determinar deveres e garantir direitos para alcançar uma solução para o problema.

Dessa forma, segundo Fábio Ulhoa Coelho, "quando o Direito considera relevante certa externalidade e determina a sua compensação, opera-se a 'internalização'. Isto é, a externalidade, que se define como efeito não compensável, deixa de ser externalidade" ${ }^{\text {"147 }}$. $\mathrm{Na}$ análise jurídica da internalização de externalidades dois entendimentos distintos se apresentam, obras de diferentes maneiras de se compreender a ação do Estado e do Direito na organização econômica: a da economia do bem-estar e a análise econômica do Direito.

O principal expoente da teoria do bem-estar é Arthur Pigou que, na década de 1920, elaborou uma crítica sistemática às "concepções clássicas de suficiência das forças livres do mercado para equilibrar os custos e benefícios sociais. As externalidades são derivadas de falhas no mercado, que cabe ao Estado corrigir, e o mecanismo por excelência para tal

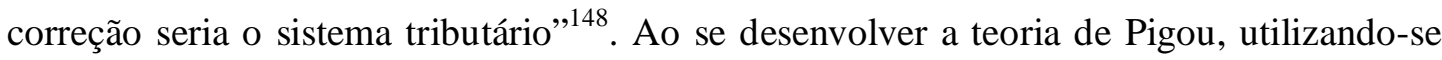
de modelos econométricos, foi possível proceder-se ao cálculo dos custos sociais e sua comparação aos custos individuais, em relação a cada atividade econômica. Do resultado dessa operação, em caso de diferença, estaria exposta a existência de uma externalidade, que o Estado, como mantenedor da sociedade, internalizaria no seguinte modo: no caso da diferença ser negativa para a sociedade, o Estado seria credor, e a empresa deveria

\footnotetext{
${ }^{146}$ Decreto-Lei no 248 , de 28 de fevereiro de 1967 - Revogada.

${ }^{147}$ Coelho, F. U. Curso de direito comercial. São Paulo: Saraiva, vol. 1, 2005, p. 34.

${ }^{148}$ Pigou, A. C. The economics of welfare. 4 ed. Londres: Macmillan and Co., vol. 1, 1932.
} 
compensar por meio de um tributo; no caso da diferença ser positiva, o Estado seria devedor e a empresa teria direito a isenções ou incentivos.

A segunda maneira de se compreender a ação do Estado e do Direito no trato das externalidades é utilizando-se a teoria da análise econômica do Direito, cujo maior expoente é Ronald Coase, que em famoso artigo de 1960 trata da visão pigouniana sobre os custos sociais e propõe um novo modelo ${ }^{149}$. Sua intenção consiste em elaborar um modelo teórico que concilie a aplicação de normas jurídicas a padrões de eficiência econômica. Com elevado toque liberal, a análise econômica do Direito acredita que as externalidades não refletem falhas do mercado, mas posições conflitantes que devem ser solucionadas pelos próprios interessados. Dessa forma, não existiria um efeito de atividade econômica que seja, em si mesmo, positivo ou negativo. Uma vez que o que é favorável a um agente econômico pode ser é desfavorável ao outro, e cada um deles buscará nortear suas opções conforme padrões racionais de eficiência, isto é, gastando o menos para lucrar o máximo possível. Coase entende que "a externalidade apenas gera ineficiência quando são elevados os custos de transação entre os agentes econômicos interessados. Isto é, quando o entendimento entre o agente que cria e o que suporta a externalidade tem um custo não desprezível" ${ }^{\prime 150}$.

É possível notar de forma clara a diferença entre a função que se espera do Estado e do Direito na conjuntura de cada uma das situações apresentadas. No caso da economia do bem-estar, o Estado é ator direto do processo de internalização das externalidades, com a obrigação precípua de mensurar e definir os custos sociais e impor a compensação aos agentes econômicos. Já, para a análise econômica do Direito, as obrigações do Estado na internalização das externalidades deve se ater à diminuição dos custos da transação entre os entes privados. Segundo Mercado Pacheco, “as normas jurídicas, em Pigou, em especial as de conteúdo tributário, são o instrumento para o Estado internalizar as externalidades; enquanto para a análise econômica do Direito, elas devem simplesmente reproduzir o mercado de competição perfeita (law as market mimiker)" ${ }^{\prime 151}$.

Pode-se perceber que as duas linhas teóricas refletem as mudanças do sistema capitalista durante o século $\mathrm{XX}$ e as respectivas tentativas de se definir limites da intervenção do Estado na economia. Todavia, segundo Fábio Ulhoa Coelho, “o primordial é que a vinculação entre tal intervenção e a luta de classes, escapa tanto à economia do

\footnotetext{
${ }^{149}$ COASE, R. The problem of social cost. Journal of law and Economics, Chicago, n. 3, 1960.

${ }^{150}$ COASE, R. The problem of social cost. Journal of law and Economics, Chicago, n. 3, 1960.
} 
bem-estar como à análise econômica do Direito. Pigou e Coase pretenderam construir modelos ideais de explicação e reorganização da economia, que definissem de uma vez por todas o campo da ingerência (e de não ingerência) do Estado na atividade econômica. Mas o fato é que a dinâmica da luta de classes obriga o aparato estatal a avanços e recuos, de modo que as orientações sobre a internalização das externalidades divisadas pelas concepções de Pigou e Coase apenas refletem momentos diferentes da história do capitalismo. O pretendido pela economia do bem-estar (utilização do sistema tributário para internalizar externalidades) e o pretendido pela análise econômica do Direito (a eficiência econômica norteando as decisões judiciais) não se realizam, e não se podem realizar, porque partem estas concepções de um pressuposto abstrato e irreal: o de que o Estado capitalista pode ter sua natureza, função e dimensão imunes aos conflitos de interesses, aos embates entre as classes sociais e seus segmentos"152.

\section{2) O Direito como custo para a atividade empresarial}

Da análise de ambos os teóricos, especialmente ao se estudar a crítica que a análise econômica do Direito faz à economia do bem-estar, no que diz respeito ao mecanismo de internalização de externalidades, é possível concluir-se com uma informação relevante, a de que não se pode ignorar a afirmação de que alguns normativos jurídicos repercutem diretamente no custo da atividade econômica. De acordo com Fábio Ulhoa Coelho, "a grande contribuição para o conhecimento jurídico, do debate entre essas correntes econômicas, não se encontra nas propostas finais de cada concepção, abstratas e irrealizáveis, mas na consideração dos marcos institucionais no universo da microeconomia". Ou seja, a capacidade de transcender o conceito de internalização de externalidades do campo econômico para o contexto da ponderação jurídica tem a grande importância de alertar para o fato de que os deveres jurídicos impostos ao agente econômico têm a natureza de elemento de custo ${ }^{153}$.

$\mathrm{Na}$ definição do preço dos seus produtos e serviços, a empresa, performa um cálculo cada vez mais elaborado, que conjuga o preço dos seus insumos, a mão-de-obra, os

${ }^{151}$ PACHECO, P. M. El analisis econômico del derecho - uma reconstrucción teórica. Madrid: Centro de Estúdios Constitucionales, 1994, p. 37.

${ }^{152}$ CoElho, F. U. Curso de direito comercial. São Paulo: Saraiva, vol. 1, 2005, p. 36. 
tributos, a margem de lucro esperada e também as contingências. Algumas dessas variáveis são objeto de contabilidade pura, sujeitas a situações controladas quantitativamente. Outros elementos, no entanto, exigem um cálculo menos ordinário, mas ainda assim indispensável à preservação da margem de lucros. Dentre esses últimos elementos encontram-se as contingências que podem ser dos mais variados tipos, como, por exemplo, risco de imagem em função de acidentes, risco trabalhista, risco governamental, risco de regulação, risco de inovação, entre outros. Tais situações podem atingir de forma relevante as contas de uma empresa, alterando a lucratividade e, em alguns casos, comprometendo a participação no mercado de atuação, por exemplo, uma emissora de televisão que perca a sua concessão de transmissão. Essas situações de difícil controle são consideradas uma segunda modalidade de cálculo, controladas qualitativamente, em direta referência à ampla gama de variáveis não inteiramente controladas por quantidades.

Assim, é possível perceber que algumas leis ou normas editadas representam para as empresas um severo elemento de custo (direito-custo). São desta natureza, por exemplo, grande parte da legislação afeta ao Direito do Trabalho, de Direito Tributário, de Direito Previdenciário, de Direito Ambiental, de Direito Urbanístico, entre outras matérias. Essas normas, direito-custo, uma vez alteradas, interferem, de várias formas, com os dados econômicos das empresas e, consequentemente, com o preço dos produtos e serviços oferecidos. Resumidamente, em cada nova obrigação a ser cumprida a empresa arca com o aumento de custos para a atividade empresarial desenvolver-se e os repassa para os seus consumidores ou adquirentes que venham na cadeia produtiva.

Conforme citado anteriormente, algumas mudanças no direito-custo podem ser facilmente absorvidas com cálculos quantitativos. Um exemplo clássico é a majoração de um tributo por parte de um Estado, o que leva a empresa a assumir tal elevação em seus custos de forma direta, calculando sem maiores dificuldades as conseqüências da mudança legislativa. No caso citado, o Direito Tributário possui princípios próprios, já bem delineados, como o da anterioridade, que representa certa garantia de objetividade e permanência para o cálculo empresarial, na medida em que separa da empresa algumas oscilações no decorrer do exercício. Outras situações de mudança no direito-custo são capazes de exigirem cálculos qualitativos, como, por exemplo, as referentes às normas de responsabilidade civil. Um exemplo é a adoção do Código de Defesa do Consumidor, em

${ }^{153}$ CoElho, F. U. Curso de direito comercial. São Paulo: Saraiva, vol. 1, 2005, p. 37. 
que a teoria da responsabilidade objetiva das empresas por acidente de consumo criou um novo elemento de curso a ser considerado pelo cálculo empresarial ${ }^{154}$.

Em qualquer das situações apresentadas, o entendimento das normas ditas de direito-custo exige a maior claridade possível, com o intuito de promover a relativa antecipação das decisões judiciais ou administrativas derivadas dessas mesmas normas. A projeção de gastos empresarial é condição precípua à sua preservação do lucro e este, por sua natureza, é o grande motivador das atividades econômicas. Em situação distinta da perspectiva de lucro, o empresário ou empreendedor dará outra destinação para seus recursos, energias e aceite de riscos. No atual modelo capitalista, o lucro é alma mater que rege as relações econômicas e conseqüentemente a vida das pessoas, portanto, negar a sua presença e importância como mola propulsora da produção e circulação de bens ou serviços, atividades indispensáveis à sobrevivência de todos, é algo que foge dos parâmetros da razoabilidade. Uma análise objetiva das normas de direito-custo está ligada ao próprio funcionamento da estrutura econômica do sistema capitalista. Nesse ponto, é de se ressaltar que a objetividade possível aqui exposta nutre tanto o cálculo matemático como o qualitativo. Ambos necessitam de informações confiáveis, embora com graus de precisão diferenciados.

No entender de Fábio Ulhoa Coelho, o dado jurídico fidedigno para fins de cálculo “é assente não somente em precedentes jurisprudenciais e modelos doutrinários, mas, sobretudo, nas variáveis próprias ao cálculo qualitativo, específico do Direito. Em outros termos, o estudioso do Direito, ao se debruçar sobre normas do direito-custo, para fornecer subsídios ao cálculo empresarial, deve estar atento às seguintes condições: a) inexistência de consenso absoluto, na comunidade jurídica, acerca da exata interpretação das normas; b) papel da ideologia e dos valores na interpretação e aplicação do Direito; c) alterações econômicas, políticas e sociais que possam interferir com o entendimento que a comunidade jurídica tem das normas em vigor. Note-se, a redemocratização do Brasil, nos fins da década de 1980, se fez acompanhar pela revalorização do Poder Judiciário, e isso acarretou mudanças sensíveis na eficácia dos princípios constitucionais do sistema tributário, por exemplo. Em termos formais, as normas constitucionais de 1969 e de 1988 não são substancialmente distintas, mas as decisões em favor do contribuinte pautadas em tais princípios foram ampliadas. Só o estudioso do Direito atento às nuanças da vida política nacional poderia estar apto a antecipar ao empresário o novo cenário"155.

${ }^{154}$ Coelho, F. U. Curso de direito comercial. São Paulo: Saraiva, vol. 1, 2005, p. 38.

${ }^{155}$ CoElho, F. U. Curso de direito comercial. São Paulo: Saraiva, vol. 1, 2005, p. 39. 
Assim, as variáveis específicas do cálculo qualitativo do Direito afastam a perspectiva de uma absoluta objetividade do custo empresarial. Por óbvio que não se pode falar em uma objetividade relativa ou em graus diferentes de precisão, mas querer quantificar com exatidão estatística a probabilidade de êxito em disputas não é equilibrável. Para Fábio Ulhoa Coelho, “a parte qualitativa do cálculo empresarial convive necessariamente com maior ou menor grau de imprecisão, e mesmo a parte desse cálculo feita por operações matemáticas (por exemplo, a base de cálculo de um imposto) pode ser afetada pela natureza retórica do conhecimento jurídico (como as divergências jurisprudenciais) ${ }^{" 156}$. No entanto, em virtude dessa bem elaborada trama, as normas jurídicas que refletem nos custos da empresa devem ser editadas, estudadas, interpretadas e aplicadas com a maior objetividade que se possa obter, de forma a congregar o Direito para o aperfeiçoamento do cálculo empresarial e, em última análise, para o desenvolvimento e organização da empresa e da economia.

Essa análise que em um primeiro momento é visualizada apenas como de Direito Comercial ou meramente econômica, possui grande influência no Direito Ambiental. Os conceitos apresentados, como externalidades e direito-custo, servem de referência no desenvolvimento de um dos princípios do Direito Internacional do Meio Ambiente, qual seja, o do desenvolvimento sustentável.

Pôde-se observar que a luta para que sejam cumpridas as obrigações que amenizam os impactos danosos à sociedade é grande. Abarcar as empresas para que as melhores práticas sejam atendidas passa pela viabilidade do custo e, consequentemente, diminuição dos lucros. Dessa forma, o Direito Internacional do Meio Ambiente, ao utilizar os mecanismos próprios do desenvolvimento sustentável, demonstra interesse em delimitar custos que possam ser revertidos de forma positiva nos números das empresas.

Nesse sentido, o próximo passo é melhor entender como surge o princípio do desenvolvimento sustentável, passando pela Conferência de 1972 em Estocolmo até a clara visualização do princípio citado, com os mecanismos criados pelos organismos internacionais que podem ser de interesse das instituições públicas e privadas.

\section{3) O Direito Internacional do Meio Ambiente a partir de Estocolmo}

${ }^{156}$ CoElho, F. U. Curso de direito comercial. São Paulo: Saraiva, vol. 1, 2005, p. 40. 
Conforme já citado anteriormente, a Conferência das Nações Unidas sobre o Meio Ambiente, em Estocolmo, no ano de 1972, pode ser considerada como o início do movimento pró-proteção do meio ambiente, muito embora os graves problemas ambientais sejam bem anteriores. Alguns estudiosos creditam ao I Congresso Internacional para a Proteção da Natureza, realizado em Paris, em 1923, um primeiro e razoável passo na abordagem das questões ambientais, todavia cumpre recordar que os muitos tratados que tratavam da fauna ou flora nesse começo de século estavam fortemente vinculados com a proteção de interesses econômicos e comerciais. Dessa forma, a idéia principal era preservar a lucratividade de empresas e sua fonte de matéria-prima. Não obstante essas situações economicamente protecionistas, existem algumas convenções importantes que foram assinadas antes de 1972, muitas delas em vigor no Brasil ${ }^{157}$.

A Conferência de Estocolmo do ano de 1972 foi a grande mentora do desenvolvimento do Direito Internacional do Meio Ambiente, uma vez que tratou dos mais variados problemas ambientais existentes. Foi por meio do Conselho Econômico e Social da ONU (ECOSOC) que a reunião foi convocada e o seu objetivo delineado, qual seja, evitar a constante degradação do meio ambiente. O pedido de realização de uma Conferência foi aprovado pela Assembléia Geral da ONU em 1968, momento em que se decidiu a sua realização para dali a quatro anos. A orientação à época era a de que, para dar certo, o Secretário Geral deveria cumprir uma agenda que incluía a consulta aos Estadosmembros, às organizações governamentais e às não-governamentais (ONGs), tentando de antemão viabilizar o sucesso do esforço dispensado. Após essas mais variadas consultas, a ECOSOC apenas tornou a se ocupar da questão no ano de 1969, recomendando que a possível Conferência não deveria se envolver em discussões sobre temas de cunho restrito, mas visar aos tópicos mais amplos de interesse geral da humanidade.

Segundo Geraldo Eulálio do Nascimento e Silva, a Assembléia Geral das Nações Unidas, em reunião ocorrida em janeiro de 1970, tomou uma série de diretivas: "aceitou o convite do Governo da Suécia, para realizar a Conferência de Estocolmo, em junho de

\footnotetext{
157 “A Convenção Internacional para a Prevenção da poluição do Mar por Óleo (Londres, 1954) é uma delas revista em 1962, sendo que 1969, duas outras convenções sobre o mesmo tema foram assinadas em Bruxelas. À época os Estados não se utilizaram de seu sentido mais amplo, politicamente foi tratada como sendo um tratado de combate a um problema específico". SilvA, G. E. do N. Direito ambiental internacional. $2^{\mathrm{a}}$ Ed., Rio de Janeiro: Thex Ed., 2002, p. 27.
} 
1972; e criou uma Comissão Preparatória, a ser integrada por peritos governamentais, para a qual o Brasil foi convidado" 158 .

A questão mais relevante durante a possível discussão do tema era a importância secundária das nações em desenvolvimento sobre o assunto. Tratar da proteção do meio ambiente com países que muitas vezes não possuem as soluções básicas para a sua subsistência poderia ser considerado como algo alvitante. Para esses países, a sobreposição de direitos que impedissem o seu desenvolvimento "a qualquer custo" seria uma espécie de afronta às necessidades prementes da população. Ademais, esses países apontavam que todos os estudos realizados e a própria filosofia da possível Conferência demonstravam a posição dos países desenvolvidos, que possuíam uma maior gama de facilidades e conhecimento das especificidades nas reuniões preparatórias.

O Brasil, desde o início das tratativas, demonstrou apego à posição da teoria desenvolvimentista, onde os países em desenvolvimento não deveriam necessariamente se ater às questões que por ventura pudessem atrapalhar o crescimento. Importante lembrar que tal posição é mero reflexo da política interna, composta de Poder Executivo forte, forças armadas atuante e Direitos Civis e Políticos sobrestados. À época, o Embaixador brasileiro Araújo Castro deixou claro que "os planos submetidos à Comissão Preparatória identificavam-se com os problemas e as preferências dos países industrializados e não levavam em consideração as necessidades e as condições dos países em desenvolvimento" ${ }^{, 159}$.

158 “A Comissão Preparatória realizou quatro sessões. A primeira ocupou-se com a parte operativa e com a definição de como os Estados-membros deveriam atuar; na segunda, foi adotada a agenda provisória e decidida a natureza do documento a ser assinado em 1972; foram abordados alguns assuntos específicos, como a poluição dos mares, a conservação do solo, os limites permissíveis de poluição e alguns outros; coube à terceira sessão examinar o progresso verificado na apreciação dos temas substantivos e apresentar o esboço de Declaração sobre o Meio Ambiente; a quarta sessão, realizada em março de 1972, ocupou-se da parte funcional da Conferência, inclusive dos aspectos financeiros. Na época, a idéia da realização de uma Conferência das Nações Unidas sobre Meio Ambiente não teve uma repercussão positiva entre os países em desenvolvimento; ao contrário, no caso de alguns, a reação foi francamente antagônica, como ocorreu com o Brasil. A razão desse desinteresse decorria de várias circunstâncias, dentre elas que a Primeira Década do Desenvolvimento das Nações Unidas chegava ao seu final com poucos resultados positivos e a Conferência era encarada como uma tática diversionista, tendente a relegar os programas de desenvolvimento a um segundo plano". Silva, G. E. do N. Direito ambiental internacional. $2^{\text {a }}$ Ed., Rio de Janeiro: Thex Ed., 2002, p. 28.

${ }^{159}$ Segundo Geraldo Eulálio do Nascimento e Silva, essa opinião refletia "a filosofia inaceitável que busca um equilíbrio ambiental global na qual certas áreas ou regiões devem ser conservadas intactas, capazes de compensar os fatores de poluição criados em abundância nos países desenvolvidos". No mesmo texto, complementou ao dizer que: “(...) a verdade indiscutível é que, no atual momento, o dilema mais urgente é dar a dois terços da Humanidade condições básicas de sobrevivência compatíveis com a dignidade do Homem”. Silva, G. E. do N. Direito ambiental internacional. 2a Ed., Rio de Janeiro: Thex Ed., 2002, p. 29. 
Com esse tipo de posicionamento declarado pelos Estados em desenvolvimento, a Assembléia Geral das Nações Unidas, em sua Resolução 2.057 (XXV), recomendou à Comissão Preparatória da Conferência incluir nas suas $2^{\mathrm{a}}$ e $3^{\mathrm{a}}$ sessões "itens específicos relativos a aspectos econômicos e sociais de interesses dos países em desenvolvimento, com vistas a reconciliar os seus planos nacionais de desenvolvimento com uma política ambiental" 160 .

A reunião preparatória ocorrida na cidade de Founex, em 1971, apresentou estudos que foram de extrema importância nessa fase instrutória. Muitos especialistas sobre o tema do meio ambiente foram convidados, o que elevou de maneira exponencial a qualidade técnica dos debates. Conseqüentemente, adotou-se um relatório abrangente sobre Desenvolvimento e Meio Ambiente, que influenciou diretamente na assinatura da Declaração de $1972^{161}$. Na referida reunião preparatória, o Brasil foi representado pelo Embaixador Miguel Osório de Almeida, um dos artífices da posição brasileira ${ }^{162}$.

Observa-se que dos apontamentos realizados em Founex muitos se encontram nos Princípios da Declaração de Estocolmo, a saber, os de número 9, 10, 11, 12, 16, 20 e 26, além da cláusula preambular, onde se indica que "nos países em desenvolvimento a maioria dos problemas ambientais são causados pelo subdesenvolvimento. Milhões continuam a viver abaixo dos níveis mínimos necessários para uma existência humana, privados de alimentos, vestimenta, abrigo, educação e saúde" ${ }^{163}$. As dúvidas existentes em

\footnotetext{
${ }^{160}$ Essas posições foram de grande valia para os temas a serem desenvolvidos na Conferência, inclusive contaram com o apoio de Maurice Strong que havia sido designado Secretário-Geral do encontro. Organização das Nações Unidas. Resoluções Assembléia Geral. Nova Iorque. 1970. Disponível em <http://www.un.org/Depts/dhl/resguide/r25.htm>. Acesso em: 03 dez. 2010.

${ }^{161}$ Segundo Maurice Strong, os países em desenvolvimento acreditavam na premissa de que a degradação do meio ambiente era um problema dos países desenvolvidos, algo que não lhes interessava, sobretudo numa fase em que o seu desenvolvimento se iniciava. A idéia básica era a de que se os danos ambientais surgissem do aumento produtivo, isso não seria um problema, devendo ser aceito de pronto. Na análise de Maurice Strong, "o relatório da reunião (de Founex) representa uma contribuição da maior importância para um completo conhecimento desse problema. Trata-se de um pré-requisito indispensável para o tipo de cooperação internacional, necessário para que a humanidade possa tratar eficientemente os novos desafios ambientais. O relatório delineia de maneira clara e convincente vários dos principais problemas com que os governos dos países mais industrializados e os países em desenvolvimento terão que se defrontar quando se reunirem em Estocolmo em 1972. Considero-o como uma das contribuições mais importantes para a preparação da Conferência e um momento histórico no diálogo desenvolvimento - meio ambiente". STRONG, M. Where on Earth Are We Going? Canadá: Alfred A. Knopf, 2000.

${ }^{162} \mathrm{Em}$ discurso perante a reunião, o posicionamento foi claro ao declarar que "se toda a poluição gerada pelos países industrializados pudesse ser retirada do mundo, a poluição mundial seria quase insignificante; ao contrário, se toda a poluição atribuível diretamente a atividades em países subdesenvolvidos pudesse ser retirada hoje do mundo, todos os perigos ligados à poluição continuariam a existir com praticamente a mesma intensidade". Nesse sentido, a posição brasileira era a de que cabia aos Estados desenvolvidos a responsabilidade maior pela criação do problema e, portanto, para a sua solução. ALMEIDA, O. Environment and Development. International Conciliation, vol. 585, jan. 1972.

163 Organização das Nações Unidas. Declaração de Estocolmo. Estocolmo. 1972. Disponível em <http://www.silex.com.br/leis/normas/estocolmo.htm>. Acesso em: 03 dez. 2010.
} 
1992 sobre o possível sucesso ou insucesso da UNCED-92 foram uma repetição do que ocorreu na Conferência de 1972, em virtude da enorme necessidade de resolução de problemas $^{164}$.

Certamente, uma das mais importantes conquistas da Declaração foi reconhecer que os problemas ambientais dos países em desenvolvimento são distintos dos problemas dos países ricos. No entanto, não se pode interpretar isto como a necessidade de se criar normas próprias ou menos rígidas para os Estados em desenvolvimento, regras estas que possam significar uma possibilidade de se poluir ou de fabricar produtos nocivos ao meio ambiente. É primordial adotar normas programáticas que sejam capazes de permitir a aceitação por grande parte dos países. De acordo com Geraldo Eulálio do Nascimento e Silva, a "adoção de regras permissivas poderá resultar na promoção, por governos sem visão, de práticas cujos malefícios exigirão mais tarde a adoção de medidas dispendiosas para sua erradicação" ${ }^{\text {"165. }}$.

No caso dos países industrializados, a colaboração deveria se dar, dentro do possível, de maneira desinteressada, por exemplo, ao ceder assistência técnica ou adotar regras claras sobre a possibilidade de exportação de produtos químicos que possam causar danos ambientais, cuja venda seja proibida no país de origem. As reclamações que surgiram contra tais abusos sempre foram pouco absorvidas, uma vez que os produtores alegavam que cabia às autoridades locais decidir se tais produtos eram ou não nocivos, apostando, neste sentido, na ignorância e na corrupção dos países em desenvolvimento. Situação conexa é a transferência de indústrias para nações onde a exigência de mão-deobra tenha um custo menor, com poucas exigências trabalhistas comparadas às de sua sede. O caso de Bhopal, na Índia, é um exemplo típico desse tipo de abuso: a empresa se instalou nessa região para a produção de pesticidas em virtude da baixa regulação de suas atividades, e em função dessa desregulação ocorreu um grave acidente com a morte de vários trabalhadores e a contaminação de grande área no entorno da planta produtiva.

\footnotetext{
${ }^{164}$ No mesmo período, enormes foram as tentativas de se abarcar em uma declaração todas as mazelas da época, desde o desajustamento de populações urbanas deslocadas para as favelas das grandes cidades até a defesa do lazer, principalmente dos anciãos. Estes problemas e outros da mesma natureza, alguns merecedores de especial atenção, foram simplesmente postos de lado. Na adoção da Declaração sobre Meio Ambiente pela Conferência em 1972, observou-se que as dúvidas e anseios eram infundados. Muitas foram as reuniões preparatórias para a Conferência, com inúmeras deliberações e estudos, além das disposições elaboradas pelas assembléias geral e da ECOSOC. Dessa forma, limitações foram necessárias para que se pudesse alcançar um consenso mínimo que avançasse no debate do meio ambiente. Esta necessidade já havia surgido em 1972 e novamente foi abordada em 1992. Em ambas as conferências, os defensores de posições mais radicais cederam ao final dos debates, buscando-se um consenso, mesmo se isto significasse a adoção de um texto que não era de seu inteiro agrado. $\mathrm{O}$ importante era evitar a adoção de um documento que fosse totalmente inaceitável para alguns.
} 
A Declaração aprovada no ano de 1972 foi bastante criticada em um primeiro momento por não haver adotado um planejamento mais rígido. Todavia, desde a sua declaração, sua influência foi exercida de maneira decisiva na defesa do meio ambiente. Os princípios nela dispostos foram devidamente incorporados por inúmeras convenções, declarações, resoluções e legislações nacionais, sendo que, com o passar dos anos, o fortalecimento do movimento ambientalista tem sido cada vez mais presente. $\mathrm{O}$ estudo da proteção do meio ambiente nas escolas primárias tem criado gerações já conscientes sobre o bom uso de materiais de consumo, bem como sobre a preservação da flora e da fauna. Assim, essa Declaração de 1972 foi capaz de iniciar um processo de comunhão internacional em busca da proteção do meio ambiente.

Passados dez anos desde a primeira Conferência, as nações observaram que os avanços tinham sido pontuais e que aumentava a destruição do meio ambiente, bem como o uso indiscriminado dos recursos não-renováveis. As várias organizações que participaram dos debates da primeira Conferência não conseguiram atender às expectativas de se criar normas legais destinadas a impedir insegurança no meio ambiente. De acordo com Geraldo Eulálio do Nascimento e Silva, "os poucos tratados internacionais firmados consolidavam a chamada soft Law em que se exortava as partes contratantes a agir desta ou daquela maneira, mas sem adotar normas capazes de obrigá-las a tanto"166.

Ao analisar os relatórios sobre o cumprimento das diretrizes da Conferência de 1972, a Assembléia Geral das Nações Unidas decidiu pela convocação de uma nova Conferência, que deveria, com antecedência, objetivar uma série de avaliações preliminares, a iniciar com a convocação de uma Comissão de alto nível, cujas conclusões deveriam servir de fonte para a Assembléia Geral que, por sua vez, recomendaria a criação de um Comitê Preparatório, bem como a realização de reuniões regionais e a colaboração das organizações não-governamentais.

No ano de 1983, a Assembléia Geral das Nações Unidas compôs a Comissão Mundial sobre Meio Ambiente e Desenvolvimento, para cuja direção foi escolhida a

${ }^{165}$ SiLva, G. E. do N. Direito ambiental internacional. $2^{\text {a }}$ Ed., Rio de Janeiro: Thex Ed., 2002, p. 32.

166 "O que se via era um desgaste cada vez maior do meio ambiente atribuído à crescente demanda de recursos escassos e pela poluição dos mares, rios e da atmosfera, causada, em 80 a $90 \%$ dos casos, pelos países industrializados. Mas, como salienta o Relatório Brundtland, a própria pobreza também polui o meio ambiente, causando outro tipo de desgaste ambiental. Para sobreviver, os pobres e os famintos muitas vezes destroem seu próprio meio ambiente; derrubam florestas, permitem o pastoreio excessivo, exaurem as terras marginais e acorrem em número cada vez maior para as cidades já congestionadas". SiLVA, G. E. do N. Direito ambiental internacional. $2^{\mathrm{a}}$ Ed., Rio de Janeiro: Thex Ed., 2002, p. 33. 
norueguesa Gro Harlem Brundtland ${ }^{167}$. Segundo declarações de Gro Harlem Brundtland, "o que a Assembléia Geral solicitava parecia irrealista e ambicioso demais, embora fosse também uma evidente demonstração do sentimento generalizado na comunidade internacional, de frustração e inadequação no tocante à nossa capacidade de enfrentar as questões vitais do mundo e lidar bem com elas". Pelo período de três anos, a Comissão visitou várias regiões e países, consultando especialistas e pessoas comuns, com reuniões deliberativas em inúmeras cidades, incluindo cidades brasileiras. Suas atividades foram encerradas em 1987 com a entrega de um Relatório à Assembléia Geral das Nações Unidas.

Tal relatório ficou mundialmente conhecido como Relatório Brundtland, e nele estão abordados os mais variados problemas, com destaque especial para as conseqüências negativas da pobreza sobre o meio ambiente. Em seus inúmeros levantamentos, um mereceu atenção diferenciada pelo governo brasileiro, uma vez que trata de um problema que aparece freqüentemente no país: "o cultivo intensivo em encostas íngremes está aumentando a erosão do solo em muitas regiões montanhosas de países desenvolvidos e em desenvolvimento. Em muitos vales fluviais, cultivam-se agora áreas onde as inundações sempre foram comuns". Esse tipo de problema atinge principalmente as populações ribeirinhas e que produzem para o próprio consumo; no entanto, com o passar do tempo, esse tipo de desgaste do solo atinge os caminhos por onde a água escorre, criando novos meandros que provocam os mais diferentes problemas, desde disputas por terra até o assoreamento de pequenos rios.

Ao se analisar o relatório apresentado, pode-se perceber que a Comissão delimitou em três grandes grupos os principais problemas ambientais. O primeiro versa "sobre problemas ligados à poluição ambiental, trata das emissões de carbono e das mudanças climatológicas, a poluição da atmosfera, a poluição da água, dos efeitos nocivos dos produtos químicos e dos rejeitos radioativos e a poluição das águas interiores e costeiras" $" 168$.

O segundo grupo trata dos "assuntos ligados aos recursos naturais, como a diminuição das florestas, principalmente das florestas tropicais, perdas de recursos genéticos; perda de pasto, erosão do solo e desertificação; mau uso da energia, especialmente lenha; uso deficiente das águas da superfície, diminuição e degradação das

${ }^{167}$ Sua composição era de dez membros escolhidos entre representantes de países em desenvolvimento e dez de países desenvolvidos, além do Presidente e do Vice-Presidente. O representante brasileiro foi Paulo Nogueira Neto. 
águas subterrâneas; diminuição dos recursos vivos do mar"169. O terceiro grupo de temas abordados mereceu um destaque especial, pois os elementos sociais, ligados ao indivíduo, passam a figurar com destaque numa relação de problemas ambientais. Os principais assuntos tratados são: uso da terra e sua ocupação, abrigo, suprimento de água e saneamento, administração do crescimento urbano acelerado, entre outras questões sociais, em especial a educação ${ }^{170}$.

Por fim, uma das sugestões finais do Relatório Brundtland foi que a Assembléia Geral das Nações Unidas deveria estudar a possibilidade de convocar uma nova Conferência para analisar os progressos obtidos. De pronto, tal sugestão foi acatada pela Assembléia e foi aprovada uma resolução no ano de 1988, indicando a necessidade de uma nova rodada de reuniões. Nascia nesse momento a futura Conferência do Rio de Janeiro do ano de $1992^{171}$.

Nos termos da Resolução 44/228, coube à Conferência analisar a situação do meio ambiente e as mudanças ocorridas desde 1972, observando não somente a Declaração inicial, mas também as convenções específicas que surgiram, como a de Viena de 1985, e o Protocolo de Montreal, de 1987, ambos de proteção à camada de ozônio, agregando ainda em conta as atividades desenvolvidas pelos países e pelas organizações intergovernamentais para proteger e melhorar o meio ambiente. A citada resolução da Assembléia Geral enumera os mais importantes tópicos abordados pela Conferência e, dentre eles, figura a melhoria das condições habitacionais e de trabalho dos pobres em favelas urbanas e em zonas rurais, mediante a eliminação da pobreza pela implementação de programas de desenvolvimento urbano e rural.

Um problema assaz discutido nas reuniões foi a resistência por parte das nações desenvolvidas em dar acesso às tecnologias ambientais apropriadas, mediante condições mais adequadas, sendo que, no caso dos países em desenvolvimento, a resolução garantia a previsão de acesso para essas tecnologias no tocante aos direitos de propriedade industrial.

Dessa resolução ainda é possível observar que a Assembléia Geral das Nações Unidas, ao convocar a Conferência sobre Meio Ambiente e Desenvolvimento, lista uma

\footnotetext{
${ }^{168}$ Nosso Futuro Comum. Comissão sobre Meio Ambiente e Desenvolvimento. Rio de Janeiro. 1988. ${ }^{169}$ Nosso Futuro Comum. Comissão sobre Meio Ambiente e Desenvolvimento. Rio de Janeiro. 1988. ${ }^{170}$ SILVA, G. E. do N. Direito ambiental internacional. $2^{a}$ Ed., Rio de Janeiro: Thex Ed., 2002, p. 35.

${ }^{171}$ É de se apontar que nesse documento estão elencados os objetivos maiores da Conferência, os tópicos a serem abordados, bem como os estudos preparatórios a serem realizados. Essa Conferência também teve uma natureza diferenciada, pois foi considerada como sendo de Cúpula, ou seja, com a máxima presença de inúmeros chefes de Estado e de Governo, além de Ministros do Meio Ambiente. O texto elaborado pelo Comitê Preparatório, a Declaração do Rio de Janeiro, submetida com anterioridade aos Estados, foi aceito pelo plenário da Conferência, além de algumas resoluções, a exemplo do que ocorreu em 1972.
} 
gama de objetivos. A Conferência deveria buscar "a defesa do meio ambiente e o desenvolvimento sustentável pelo qual a humanidade é capaz de atender às necessidades do presente, sem comprometer a capacidade de as gerações futuras atenderem também às suas. Dentre os objetivos mencionados pela resolução figura, prioritariamente, o exame do estado do meio ambiente e as mudanças verificadas desde a Conferência de Estocolmo, de 1972, e a adoção de uma série de tratados e decisões de cunho ambiental" ${ }^{172}$.

A Resolução 44/228 da Assembléia Geral indica, dentre os objetivos da Conferência, o desenvolvimento do Direito Ambiental Internacional, e a elaboração de direitos e obrigações genéricas das nações baseando-se nos mais importantes documentos jurídicos a respeito. Estão inseridos na Declaração do Rio os direitos e as obrigações cujo valor jurídico nem sempre é similar, uma vez que alguns dos princípios elencados já podem ser considerados regras de Direito Internacional, na medida em que outros ainda não se revestem de tal característica.

No entender de Geraldo Eulálio do Nascimento e Silva, a Declaração consagra as seguintes regras de Direito Internacional do Meio Ambiente: "o direito soberano dos Estados de explorar e utilizar os seus recursos naturais de conformidade com as suas políticas ambientalistas; a responsabilidade internacional por dano ocorrido além das fronteiras nacionais; o dever de evitar o dano ambiental grave em outros Estados; a obrigação de desenvolver o Direito Internacional no campo da responsabilidade (liability); o dever de consulta prévia ao iniciar obras suscetíveis de provocar dano ambiental em outros Estados; o dever de notificar imediatamente aos demais Estados e organizações internacionais, no caso de acidente capaz de provocar dano ambiental grave; o dever de adotar legislação ambiental efetiva; o dever de cooperar de boa-fé com os demais Estados na defesa efetiva do meio ambiente; o dever de solucionar pacificamente as controvérsias internacionais ambientais",173.

A Assembléia Geral também entendeu que era necessário identificar novas formas de financiamento das metas a serem atingidas. Nesse sentido, a última cláusula preambular da resolução, que convocou a Conferência do Rio de Janeiro, reconhece que "novos e adicionais recursos financeiros deverão ser encaminhados aos países em desenvolvimento,

\footnotetext{
${ }^{172}$ SILVA, G. E. do N. Direito ambiental internacional. $2^{\text {a }}$ Ed., Rio de Janeiro: Thex Ed., 2002, p. 37.

${ }^{173}$ SiLVA, G. E. do N. Direito ambiental internacional. $2^{\text {a }}$ Ed., Rio de Janeiro: Thex Ed., 2002, p. 38.
} 
a fim de garantir a sua plena participação no esforço global em defesa do meio ambiente" ${ }^{, 174}$.

A transferência de tecnologia ambiental e o acesso de maneira equânime e a preço franco de tecnologias economicamente racionais foram uns dos principais objetivos dos Estados em desenvolvimento durante a Conferência ${ }^{175}$. O tema da transferência da tecnologia é elevadamente complexo, a iniciar com a relutância das multinacionais em abrir mão de patentes adquiridas após larga pesquisa e alto investimento. Nesses casos, é óbvio que a vontade política não se adequa às necessidades e motivos empresariais, uma vez que seria necessária a concordância dos detentores das patentes ${ }^{176}$. De qualquer modo, esse tipo de transferência apenas se concretiza com a conjugação da obtenção dos recursos financeiros e da vontade dos detentores de patentes em cedê-las, nem que seja mediante pagamento.

Expõe Geraldo Eulálio do Nascimento e Silva que durante a convocação da Conferência, a Assembléia Geral frisou que, dentre os seus objetivos, deveria "figurar o desenvolvimento do direito ambiental internacional, tendo em vista não só a Declaração de Estocolmo, de 1972, mas também alguns pronunciamentos relevantes de natureza legal. A Declaração do Rio de Janeiro, ao enumerar uma série de direitos e obrigações foi um passo além da recomendação da Assembléia Geral, visto que, no Princípio 27, se acolheu o princípio de que os Estados e os povos devem cooperar "para o desenvolvimento progressivo do Direito Internacional no campo do desenvolvimento sustentável”. Em

\footnotetext{
${ }^{174}$ Os aportes financeiros se destinam não somente à implementação dos programas ambientais nacionais, mas também aos programas globais, nos quais muitos países estão empenhados, como no combate à poluição da atmosfera e dos mares. A Assembléia Geral indicou a hipótese de ser criado um fundo destinado à transferência em condições favoráveis das tecnologias ambientais. Sua constituição deveria se dar adotando o princípio do poluidor-pagador, pelo qual os poluidores, ou mais precisamente os países industrializados, teriam que arcar com $80 \%$ do valor destinado ao fundo.

175 A Declaração do Rio estabelece que "os Estados devem cooperar com vistas ao fortalecimento da capitação endógena para o desenvolvimento sustentável, pelo aprimoramento da compreensão científica por meio do intercâmbio do conhecimento científico e tecnológico e pela intensificação do desenvolvimento, adaptação, difusão e transferência de tecnologias, inclusive tecnologias novas e inovadoras" (Princípio 9). Organização das Nações Unidas. Declaração do Rio. Rio de Janeiro. 1992. Disponível em <http://www.mma.gov.br/sitio/index.php?ido=conteudo.monta\&idEstrutura=18\&idConteudo=576>. Acesso em: 03 dez. 2010.

${ }^{176}$ A Convenção de Viena sobre a Proteção da Camada de Ozônio tem um apontamento nessa linha, mas foi no Protocolo de Montreal sobre substâncias que destroem a camada de ozônio (1987) que se pôde observar a idéia exposta de maneira mais aberta. A Resolução 44/228 de 1989, ao optar pelo acesso à tecnologia ambiental em condições favoráveis, salientou que os direitos de propriedade deveriam ser levados em consideração. As tecnologias novas não são necessariamente de propriedade exclusiva do setor privado, pois podem também ser do setor público, como no caso da quebra de patentes para os remédios de combate à AIDS. Importante salientar que ao inventor deve ser dada a remuneração justa por sua pesquisa com vistas ao binômio pesquisa-desenvolvimento.
} 
outras palavras, criou uma obrigação mais ampla, com ênfase na questão do desenvolvimento" ${ }^{\prime 177}$.

Um dos tratados internacionais resultante da reunião do Rio de Janeiro em 1992 foi a Convenção Quadro das Nações Unidas sobre a Mudança do Clima (CQNUMC). Este foi firmado por quase a totalidade das nações e tem como objetivo principal a estabilização da concentração de Gases do Efeito Estufa (GEE) na atmosfera em níveis tais que evitem a interferência danosa com o sistema climático ${ }^{178}$.

Em um primeiro momento, o tratado não fixou limites taxativos para as emissões de GEE, bem como não dispunha de módulos coercitivos. Em vez disso, o tratado incluía disposições para atualizações, os chamados "protocolos", que deveriam criar faixas obrigatórias de emissões. O Protocolo mais conhecido é o discutido e finalizado na cidade de Quioto no Japão. A necessidade de se criar mecanismos que tratem dos GEE é muito importante, uma vez que esses gases permanecem no ambiente por muitas décadas, não sendo possível a sua interrupção ou reversão no quesito mudança climática. Dessa forma, as medidas a serem tomadas são mitigadoras, no sentido de diminuir o impacto de tais mudanças, e adaptadoras, no sentido de criar mecanismos de adaptação às mudanças que irão ocorrer.

Dentre os princípios elencados no primeiro capítulo dessa dissertação, a Convenção assenta naquele da responsabilidade comum, porém diferenciada. Tendo em vista que a concentração atual de GEE na atmosfera é fruto, em grande parte, das emissões realizadas por países industrializados em épocas passadas, cada nação tem uma responsabilidade diferenciada. Para a divisão de responsabilidades, os Estados foram divididos em blocos distintos.

O Anexo I é considerado como um dos blocos da Convenção. Nele estão contidos os países mais poluidores e que deverão atuar de forma mais ampla para reduzir os níveis de poluição. O Anexo II é composto pelos países do Anexo I, excetuando aqueles cuja política econômica esteja em transição para uma economia de livre mercado. Esses países têm especial obrigação de ajudar com recursos financeiros e tecnológicos os países em desenvolvimento. Os países em desenvolvimento são também chamados de países do não Anexo I e estes não têm metas de redução de emissão.

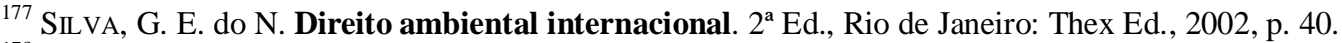

${ }^{178}$ Esse volume de concentração segura para o clima ainda não é conhecido. Grande parte da comunidade científica considera que, se a emissão destes gases continuar crescendo no ritmo atual, advirão danos cada vez mais gravosos ao meio ambiente.
} 
Os Estados membros da Convenção encontram-se periodicamente nas reuniões chamadas Conferência das Partes. A primeira Conferência das Partes (COP-1) ocorreu em 1995 na cidade de Berlim, sendo firmado nessa oportunidade o Mandato de Berlim, no qual os países do Anexo I assumiram maiores compromissos com o equilíbrio da concentração de GEE, por meio de políticas, mecanismos ou metas quantitativas de redução de emissões.

Em 1997 foi devidamente aprovado o Protocolo de Quioto, que seguiu as diretrizes da COP-1 e enfatizou os intentos quantitativos como forma de minimizar os custos de mitigação em cada nação. Com este objetivo também foram estabelecidas sistematizações como o Mecanismo de Desenvolvimento Limpo (MDL), que possibilita tanto a diminuição de emissões em países do não Anexo I do Protocolo, quanto a transferência de recursos dos países do Anexo I aos países em desenvolvimento ${ }^{179}$.

${ }^{179}$ O Protocolo de Quioto é consequência de uma série de eventos iniciada com a Toronto Conference on the Changing Atmosphere, no Canadá (outubro de 1988), seguida pelo IPCC's First Assessment Report em Sundsvall, Suécia (agosto de 1990), e que culminou com a Convenção Quadro das Nações Unidas sobre a Mudança Climática (CQNUMC) na ECO-92 no Rio de Janeiro, Brasil. Desde meados da década de 1980 se discutem mudanças climáticas globais na esfera internacional. Tal processo resultou na realização da Conferência das Nações Unidas para o Meio Ambiente e Desenvolvimento - CNUMAD, realizada no Rio de Janeiro em 1992, que gerou, entre outros documentos, a Convenção Quadro de Mudanças Climáticas. Passados cinco anos, houve o estabelecimento do Protocolo de Quioto que, diferente da Convenção, estabeleceu normas mais claras sobre a redução de emissões de gases de efeito estufa e metas a serem atingidas por países que emitiram mais gases no passado, arrolados no Anexo I. Por ele se propõe um calendário pelo qual os países-membros (principalmente os desenvolvidos) têm a obrigação de reduzir a emissão de gases do efeito estufa em, pelo menos, 5,2\% em relação aos níveis de 1990 no período entre 2008 e 2012, também chamado de primeiro período de compromisso (para muitos países, como os membros da UE, isso corresponde a $15 \%$ abaixo das emissões esperadas para 2008). As metas de redução não são homogêneas a todos os países, colocando níveis diferenciados para os 38 países que mais emitem gases. Países em franco desenvolvimento (como Brasil, México, Argentina e Índia) não receberam metas de redução, pelo menos momentaneamente. A redução dessas emissões deverá acontecer em várias atividades econômicas. O protocolo estimula os países signatários a cooperarem entre si, através de algumas ações básicas: reformar os setores de energia e transportes; promover o uso de fontes energéticas renováveis; eliminar mecanismos financeiros e de mercado inapropriados aos fins da Convenção; limitar as emissões de metano no gerenciamento de resíduos e dos sistemas energéticos; proteger florestas e outros sumidouros de carbono. Se o Protocolo de Quioto for implementado com sucesso, estima-se que a temperatura global reduza entre $1,4^{\circ} \mathrm{C}$ e $5,8^{\circ} \mathrm{C}$ até 2100 , entretanto, isto dependerá muito das negociações pós período $2008 / 2012$, pois há comunidades científicas que afirmam categoricamente que a meta de redução de $5 \%$ em relação aos níveis de 1990 é insuficiente para a mitigação do aquecimento global. Após a elaboração do Protocolo de Quioto, iniciou-se um período conturbado para a definição das regras operacionais. A reunião da COP-6, em novembro de 2000, em Haia, foi suspensa em função da divergência de entendimentos entre os Estados Unidos da América e países europeus, o que gerou o anúncio americano, no ano seguinte, de que não iria participar das negociações de implementação do Protocolo de Quioto. Em 2001 foi retomada a discussão da COP-6 em Bonn, no que ficou conhecida como COP-6 BIS. Esse encontro estabeleceu o Acordo de Bonn, no qual foram feitas concessões de modo a permitir a permanência de nações como o Japão e a Rússia, necessária para a entrada em vigor do Protocolo. Também, durante a elaboração do acordo, foi permitida diferentes interpretações quanto a temas como o uso do solo e florestas, por Estados que passaram a revisar suas posições quando da saída dos Estados Unidos da América e das concessões realizadas a outros países. Com a realização da COP-7 foi obtido o Acordo de Marraquexe, que contemplava alguns aspectos políticos do Acordo de Bonn e ambientais do Protocolo de Quioto. Este acordo definiu as normas operacionais para o uso do solo e florestas, mecanismos de flexibilização, definição do sistema nacional de inventários de emissões, informações adicionais derivadas do Protocolo de Quioto e do processo de revisão das 
Em 2000, as Nações Unidas adotaram uma resolução sobre a preparação da reunião que ficou conhecida como RIO +10 , cuja designação oficial é Cúpula Mundial para o Desenvolvimento Sustentável, realizada em Johanesburgo, África do Sul, em 2002. De acordo com a resolução, as diretivas adotadas pelas nações durante a Rio 92 deveriam passar por um processo exaustivo de monitoramento e avaliação dez anos depois da primeira Cúpula da Terra, no Rio de Janeiro. Decidiu-se pela avaliação da efetividade da implementação da Agenda 21, nas cidades, nos países, nas regiões e no âmbito global, contando com a participação de governos e organismos internacionais, organizações nãogovernamentais, organizações profissionais, sindicatos, segmentos do mercado, povos indígenas, academias, entre outros ${ }^{180}$.

Em Nova Iorque, após cinco anos, na Rio +5 , intentou-se uma primeira avaliação sobre a efetiva implementação das decisões tomadas no Rio de Janeiro. Os resultados foram por demais simples: havia decorrido pouco tempo para que mudanças importantes e necessárias para impulsionar a economia mundial em transformações de vulto já se encontrassem em funcionamento.

Na ocasião da Rio +10 , por sua vez, foram elaborados dois documentos oficiais: a Declaração Política e o Plano de Implementação. Esses documentos refletiam algumas limitações do próprio processo decisório vigente nas Conferências elaboradas pelo sistema das Nações Unidas, baseado na necessidade de consenso e na igualdade de valor do voto de todos os países. Dessa forma, os resultados constituem o mínimo denominador comum

comunicações nacionais. Nesse momento, percebeu-se que mesmo que as reduções previstas no Protocolo de Quioto sejam atingidas, estas não serão suficientes para diminuir exponencialmente a interferência dos indivíduos no clima. Na COP-7 foi instituído também o Comitê Executivo do MDL e elaborada uma declaração que enfatizava a relação entre desenvolvimento sustentável e mudanças climáticas, apontando como prioridade nas nações em desenvolvimento a erradicação da pobreza e o desenvolvimento. A preocupação com o modelo de trabalho de Quioto e sua discussão oficial iniciou-se na COP-11, em Montreal. Têm ocorrido discussões sobre o que deve ser feito após 2012 e como incluir países em desenvolvimento (principalmente China, Índia e Brasil) na questão da limitação das emissões, o que é uma questão problemática já que neste bloco encontram-se tanto países muito pobres, como aqueles do continente africano, quanto o país com a maior taxa de crescimento no mundo e, em breve, um dos maiores emissores de GEE, a China. A COP-13 de 2007, na Indonésia, definiu as primeiras diretrizes para o acordo sobre o que analisar após 2012, quando vence o protocolo de Quioto, mas foi considerado um acordo vago. Por fim, a COP-14, 2008, na Polônia e COP-15, 2009, na Dinamarca, sofreram as maiores pressões por parte da sociedade civil, sendo que ao final os grande temas acabaram por não receber o devido tratamento dos países mais desenvolvidos. Essa posição foi justificada em função da crise de 2008 e os desdobramentos de uma recessão econômica que se avizinha.Organização das Nações Unidas. Protocolo de Quioto. Quioto. 1997. Disponível em <http://www.onu-brasil.org.br/doc_quioto.php>. Acesso em: 03 dez. 2010.

${ }^{180}$ No ano de 1992 as nações haviam se comprometido a, de forma conjunta, cumprir as decisões contidas em cinco documentos, que são a Carta da Terra, a Agenda 21, as duas convenções assinadas naquela ocasião como a Convenção sobre Mudanças do Clima e a de Diversidade Biológica e a Declaração de Princípios sobre Manejo das Florestas. 
entre as posições de todos os países presentes à Conferência, não se concatenando às graves necessidades do planeta que requerem medidas mais severas e eficazes.

A Declaração Política, chamada de "O Compromisso de Joanesburgo sobre Desenvolvimento Sustentável", trata-se de documento que estabelece posições programáticas, e não metas. Assim, reafirma princípios e acordos adotados na Estocolmo 72 e na Rio 92, demanda o sobrestamento da dívida externa dos países em desenvolvimento e o aumento da assistência financeira para os países pobres, além de apontar que os desequilíbrios e a má distribuição de renda, tanto entre países quanto dentro deles, estão no cerne do desenvolvimento insustentável. O documento ainda aponta para o insucesso da Rio 92 e clama à Organização das Nações Unidas a instituir um mecanismo de acompanhamento das decisões tomadas na Cúpula de Johanesburgo.

O outro documento importante foi o resultante da Cúpula, o Plano de Implementação. Seu objetivo principal é alcançar três metas supremas: a erradicação da pobreza, a mudança nos padrões insustentáveis de produção e consumo e a proteção dos recursos naturais. Segundo Geraldo Eulálio do Nascimento e Silva, "um dos pontos mais relevantes do documento é o tratamento de temas antigos de uma forma que reflete a evolução no cenário internacional desde 1992" ${ }^{\prime 181}$.

De fato, várias das metas estabelecidas no Plano de Implementação já tinham sido determinadas em um outro momento em documentos como a Declaração do Milênio da ONU, mas não se pode confinar a importância da Conferência de Johanesburgo apenas aos seus dois documentos oficiais. Por agregar representantes de todos os setores da sociedade, o encontro possibilitou e facilitou um diálogo entre eles, resultando no anúncio de uma série de iniciativas governamentais e não-governamentais, as chamadas Iniciativas de Tipo II, que dão apoio a muitos dos compromissos firmados pelo Plano de Implementação ${ }^{182}$.

${ }^{181}$ Agência Nacional de Águas. Os Resultados da Conferência - Rio+10. Brasília. 2002. Disponível em <http://www.ana.gov.br/AcoesAdministrativas/RelatorioGestao/Rio10/riomaisdez/index.php.39.html>. Acesso em: 03 dez. 2010.

182 "Para melhorar o acesso ao saneamento básico, por exemplo, os Estados Unidos anunciaram investimentos no valor de US\$ 970 milhões; a União Européia anunciou a criação do projeto “Água para a Vida" e a ONU recebeu, ainda, outras 21 iniciativas relacionadas, que somam outros US\$ 20 milhões. Os Estados Unidos e os países europeus também se comprometeram a reunir cerca de US\$ 743 milhões em investimentos na área de energia. Também sobre essa questão, as nove maiores indústrias produtoras de energia assinaram uma série de acordos com a ONU para facilitar a cooperação técnica no desenvolvimento de projetos de energia sustentável nos países em desenvolvimento. Os países desenvolvidos anunciaram ainda outras iniciativas importantes nas áreas de agricultura, saúde e biodiversidade, entre outras. Ao todo, foram formalizadas durante a cúpula cerca de 280 parcerias". Os Resultados da Conferência - Rio+10. Brasília. $2002 . \quad$ Disponível em <http://www.ana.gov.br/AcoesAdministrativas/RelatorioGestao/Rio10/riomaisdez/index.php.39.html>. Acesso em: 03 dez. 2010. 
É bastante dificultoso negar que os interesses divergentes dos países restringem, e muito, o produto final de conferências promovidas pela Organização das Nações. Porém, não se pode ignorar a função particular que cúpulas como essas têm de realizar acordos globais, além de acelerar mudanças que acontecem posteriormente em comunidades e instituições públicas e privadas em todo o mundo. Assim como em Estocolmo 72 e na Rio 92, os Estados só se deram conta das conseqüências da Conferência de Johanesburgo nos anos que se seguiram.

\section{4) Desenvolvimento Sustentável}

Com o histórico de debates e convenções apontado no item anterior, é possível ter uma visão ampla de como o Direito Internacional tratou do desenvolvimento do tema meio ambiente em seus domínios. Muitos esforços foram realizados com grandes vitórias, exemplo do combate aos Clorofluorcarbonetos, e algumas derrotas, como a dificuldade na ratificação dos termos do Protocolo de Quioto e os impasses nas mais recentes COPs. Todavia, alguns princípios e normas elaborados criaram conceitos e modelos que começaram a ser estudados pelos Estados e foram devidamente aplicados por vários governos em muitos âmbitos.

Dentre os mais variados princípios, é importante apontar o desenvolvimento sustentável como um dos mais importantes, senão o mais pró-ativo e melhor absorvido pela sociedade mundial. Esse princípio possui uma faceta de fácil recepção que começou a ser utilizada por organizações internacionais, organismos públicos, privados, organizações não-governamentais e sociedade civil.

Dessa forma, uma análise mais aprofundada de seu conceito e modus operandi, possibilita identificar como este princípio em especial tem sido absorvido por um grande número de empresas, especialmente as transnacionais, para melhor se situarem em uma perspectiva sócio-ambiental, além de garantir sua lucratividade.

A Comissão Mundial sobre Meio Ambiente e Desenvolvimento, ao concluir o seu trabalho, em 1987, apontou que existia um problema primordial a ser resolvido: "muitas das atuais tendências do desenvolvimento resultam em número cada vez maior de pessoas pobres e vulneráveis, além de causarem dano ao meio ambiente”. No parecer da Comissão, "era necessário um novo tipo de desenvolvimento capaz de manter o progresso humano 
não apenas em alguns lugares por alguns anos, mas em todo o Planeta até um futuro longínquo". A idéia indicada pela Comissão foi a teoria do desenvolvimento sustentável.

Essa teoria se mostrou uma constante em vários documentos tratados durante a Conferência do Rio de Janeiro sobre Meio Ambiente e Desenvolvimento, principalmente a Agenda 21. Tal teoria é mais bem compreendida a partir do ano de 1970, quando um estudo elaborado por especialistas do Instituto de Tecnologia de Massachusetts (MIT) foi encaminhado ao Clube de Roma, composto por vários estudiosos desassossegados com o futuro da humanidade. Sob a orientação de Donella Meadows, em 1974, foi publicado um relatório com o título "The Limits of Growth", que teve larga repercussão internacional. Na pesquisa elaborada, os especialistas, utilizando-se de instrumentos modelados, com sofisticado sistema tecnológico, simularam diversas interações com numerosas e complexas variáveis, concluindo que, no caso de se manterem inalteradas as taxas de crescimento da população, da utilização de recursos não-renováveis, da produção de bens industriais e de alimentos, e do aumento da poluição, o mundo seria levado, no século XXI, a incontroláveis cataclismas, seja por falta de alimentos, ou por envenenamento da água e do ar, ou, mais particularmente, pela falta de recursos não-renováveis. Em um sentido simples, era o retorno da teoria malthusiana, ou seja, à idéia do crescimento zero ${ }^{183}$.

Após, observou-se que as perspectivas não correspondiam à realidade, o mesmo no tocante às projeções de taxas de crescimento, especialmente aquelas relativas aos países em desenvolvimento; ainda por cima, pormenorizava a capacidade dos países de responder aos desafios de toda a humanidade. Embora o relatório de 1974 tenha deixado de merecer uma maior aceitação, sua publicação teve o intuito de elevar a discussão sobre o crescimento econômico para um patamar até então não atingido, afirmando que nenhuma nação deve ter como única atividade fim, o crescimento pelo crescimento. Da mesma forma, o relatório identificou que a situação dos países em desenvolvimento deveria ser melhorada, porém não apresentou diretivas objetivas de como proceder.

Independente das críticas que caíram sobre o relatório, ele foi de grande valia para que os países pudessem iniciar um processo de sensibilização quanto aos danos ao meio ambiente. Da mesma forma, este foi utilizado em várias das reuniões até a estabilização de que o conceito entre meio ambiente e desenvolvimento econômico não era antagônico.

A Assembléia Geral das Nações Unidas em, 1982, ao estudar os resultados alcançados em 1972, constatou que o progresso havia sido mínimo: a poluição,

${ }^{183}$ SILVA, G. E. do N. Direito ambiental internacional. $2^{\mathrm{a}}$ Ed., Rio de Janeiro: Thex Ed., 2002, p. 47. 
principalmente da atmosfera, aumentara e a degradação ambiental não cessara. Foi criada a Comissão Mundial sobre Meio Ambiente e Desenvolvimento, com a intenção de propor novos mecanismos tendentes ao combate da degradação ambiental e a melhoria das condições de vida das populações mais pobres. Aos poucos a Comissão Mundial consolidou posição e a solução acolhida ao final foi o que se convencionou denominar desenvolvimento sustentável ${ }^{184}$.

A Comissão Mundial demonstrou que o conceito de desenvolvimento sustentável possuía limites, "não limites absolutos, mas limitações impostas pelo estágio atual da tecnologia e da organização social no tocante aos recursos ambientais e pela capacidade da biosfera de absorver os efeitos de atividades humanas" 185 .

A conceituação teve grande aceitação, principalmente na necessidade de se preservar os bens para as nações futuras. A resolução de dezembro de 1989, com a qual a Assembléia Geral das Nações Unidas solicitou a Conferência do Rio, salienta que a Conferência deveria "adotar estratégias e medidas capazes de sustar e reverter a degradação ambiental, baseada em esforços nacionais e internacionais mais intensos para promover um desenvolvimento sustentável e ambientalmente sadio em todos os países" ${ }^{186}$.

No ano de 1991, durante uma Conferência realizada em Copenhague, sob a organização da UNIDO (Organização das Nações Unidas para o Desenvolvimento Industrial), foi adotada uma definição de desenvolvimento industrial ecologicamente sustentável que congrega esta filosofia: "Sistemas de industrialização que põem em relevo a contribuição da indústria aos benefícios econômicos e sociais para as gerações atuais e futuras, sem prejuízo do processo ecológico básico". Ou seja, para que o desenvolvimento seja sustentável, não basta que seja ambientalmente sustentável, mas deve objetivar igualmente às dimensões sociais, econômicas, políticas e culturais do desenvolvimento ${ }^{187}$.

A Declaração do Rio de Janeiro, de 1992, reza, em seu artigo 4, que "para se alcançar um desenvolvimento sustentável, a proteção ambiental deve constituir parte integrante do processo de desenvolvimento e não pode ser considerada separadamente, o que implica na adoção, pelos Estados, de estratégias, programas e planos que integrem a proteção ambiental e o desenvolvimento econômico, com base no uso equitativo dos

\footnotetext{
184 "Desenvolvimento sustentável é o desenvolvimento capaz de garantir as necessidades do presente sem comprometer a capacidade das gerações futuras de atenderem as suas necessidades”. Nosso Futuro Comum. Comissão sobre Meio Ambiente e Desenvolvimento. Rio de Janeiro. 1988.

${ }^{185}$ Nosso Futuro Comum. Comissão sobre Meio Ambiente e Desenvolvimento. Rio de Janeiro. 1988. ${ }^{186}$ SILVA, G. E. do N. Direito ambiental internacional. $2^{\text {a }}$ Ed., Rio de Janeiro: Thex Ed., 2002, p. 49.

${ }^{187}$ Conference on Ecologically Sustainable Industrial Development. UNIDO. Viena. 1991.
} 
recursos naturais, em prol desta geração e das gerações que nos sucederem"188. De acordo com Dupuy, este artigo pode ser entendido como uma "matriz conceitual", cujas referências "nos preâmbulos ou nas disposições jurídicas interessadas na matéria" quadram como orientação às políticas de desenvolvimento referentes à proteção internacional do meio ambiente, exprimindo, assim, uma opinium juris ${ }^{189}$. Cesáreo Guttierrez Espada também acolhe ser o princípio de desenvolvimento uma matriz conceitual ${ }^{190}$.

A Convenção Quadro sobre Mudança do Clima, em seu artigo $3^{\circ}, \S 1^{\circ}$, ao tratar dos princípios direcionadores dos atos para se obter o objetivo da convenção e implementar as suas disposições, recomenda que as Partes devem resguardar o sistema climático em benefício das gerações, presentes e futuras da humanidade com base na equidade. Para compreender melhor o conceito de equidade entre as gerações, disposto no princípio do desenvolvimento sustentável, pode-se analisar os estudos de Edith Brown Weiss que explica o conceito de equidade intergeracional ${ }^{191}$.

Resumidamente, equidade intergeracional é um processo dinâmico que cria responsabilidades e obrigações de precaução para cada uma das gerações entre si e para com as outras que virão no futuro, de forma a ajustar um perímetro à ação humana relativamente à utilização dos recursos da Terra ao longo do tempo, objetivando a partilha

188 Organização das Nações Unidas. Declaração do Rio. Rio de Janeiro. 1992. Disponível em <http://www.mma.gov.br/sitio/index.php?ido=conteudo.monta\&idEstrutura=18\&idConteudo=576>. Acesso em: 03 dez. 2010.

${ }^{189}$ DupuY, P. M. Où em est Le droit international de l'environment à la fin du siècle? Revue Génerale de Droit Public. Paris, Tome 101, 1997, p. 886/887.

190 “O princípio de desenvolvimento sustentável não é, a rigor, uma norma jurídica que pode ser diretamente aplicável. Trata-se de um princípio geral desprovido de caráter normativo e que, em contraposição às regras ou normas jurídicas, somente de forma limitada pode ser objeto de aplicação direta. Tratar-se-ia de uma matriz conceitual, um princípio inspirador de análises e regras jurídicas, que teria um papel análogo ao de outros grandes princípios do Direito Internacional, como o da soberania do Estado ou da autodeterminação dos povos". EsPADA, C. G., La Contribuition del Derecho Internacional del Medio Ambiente al Desarrolo del Derecho Internacional Contemporâneo. Anuário de Derecho Internacional. Vol. XIV, 1998, p. 179.

191 "Direitos e obrigações planetárias coexistem em cada geração. Na dimensão intergeracional, as gerações para as quais as obrigações são devidas são as futuras gerações enquanto que as gerações com as quais os direitos estão vinculados são as gerações passadas. Desta forma, os direitos das futuras gerações estão vinculados às obrigações das presentes gerações. No contexto intergeracional, as obrigações e direitos planetários existem entre membros da presente geração. Eles derivam do relacionamento intergeracional que cada geração compartilha com aqueles que vieram anteriormente e com aqueles que ainda estão por vir. Então, obrigações internacionais para conservar o planeta fluem da geração presente para as gerações futuras como gerações e para os membros da presente geração, que têm o direito de usar e de usufruírem o legado planetário". BRown WEISS, E. "International Equity: A legal framework for a global environmental change" in Environmental Change and International Law: New Challenges and Dimensions. New York: United Nations University Press, 1992, p. 406. 
equitativa dos bens ambientais comuns para resguardá-los de seu fim e transmiti-los às inúmeras gerações futuras a partir de um comportamento de prudência atual ${ }^{192}$.

Importante frisar que a consolidação do desenvolvimento sustentável passa pela necessidade dos diferentes agentes sociais estabelecerem um amplo consenso entre si, por meio da articulação e da introdução de novas desenvolturas e conhecimentos, sob um mecanismo de responsabilidade social comum, mas diferenciada, assente nos princípios de cooperação, de precaução e de equidade coordenado pelos Estados.

Para Lucila Fernandes Lima, a "tarefa de planejar e implementar políticas sociais e econômicas para dar suporte ao desenvolvimento sustentável no âmbito local, nacional, regional e global cabe aos Estados que, pela internalização dos princípios internacionais em suas normas internas e pela aplicação das decisões havidas nos acordos internacionais, implementam novas regras e padrões. Essas regras e padrões, no decorrer do tempo, uma vez implantadas, têm a função de reordenar os processos produtivos das empresas, o uso dos recursos naturais e o modo de agir da sociedade civil em prol de um sistema de gestão ambiental sustentável mais global”193.

Em conformidade com a Declaração das Nações Unidas, elaborada pela Assembléia Geral à Cúpula do Milênio, em 2000, a administração dos recursos ambientais, baseado na prudência e em atitudes pró-ativas, é instrumental para se transmitir às gerações futuras o legado ambiental.

Segundo Lucila Fernandes Lima, o desenvolvimento sustentável tem um poder interessante a ser utilizado no caso das políticas para a redução dos GEE, especialmente na incorporação da produção de energias renováveis e de procedimentos ecologicamente racionais, na utilização do solo de forma adequada e na mudança do atual modelo de produção agrícola e de gestão florestal. "Nessa esteira, a aplicação do princípio de desenvolvimento sustentável relaciona-se diretamente com a estruturação da proteção ao meio ambiente em nível global, cujo aspecto multidisciplinar envolve os mais diversos

${ }^{192}$ LiMA, L. F. A moldura regulatória internacional do mecanismo de desenolvimento limpo do protocolo de Quioto. 2003. 349 p. Dissertação (Mestrado). Faculdade de Direito da Universidade de São Paulo, São Paulo, 2003.

${ }^{193}$ Segundo Cristiane Derani, o princípio de desenvolvimento sustentável é entendido como um direito do desenvolvimento sustentável, cuja base estaria na "preocupação de garantir a manutenção das bases vitais de produção e a reprodução do homem e de suas atividades, garantindo igualmente uma relação satisfatória entre os homens e destes com o meio ambiente". A jurista demonstra que esse "direito do desenvolvimento sustentável aporta essencialmente normas capazes de instrumentalizar políticas de desenvolvimento sustentável com base no aumento de qualidade das condições de existência dos cidadãos”. DERANI, Cristiane, Direito Ambiental Econômico. São Paulo: Editora Max Limonad, 1997, p. 169 a 171. LiMA, L. F. A moldura regulatória internacional do mecanismo de desenolvimento limpo do protocolo de Quioto. 2003. 349 p. Dissertação (Mestrado). Faculdade de Direito da Universidade de São Paulo, São Paulo, 2003. 
campos do conhecimento humano (como a economia, o direito, a física, a química aplicada, a engenharia e outros), e poderá representar o esforço da comunidade internacional à remodelação do sistema econômico, essencial à mitigação dos problemas ambientais"194.

As políticas de desenvolvimento sustentável, com o passar dos anos, começaram a integrar o ordenamento de diversos países preocupados com os graves danos e acidentes que começaram a surgir em seus territórios. Países cuja flora e fauna ainda são extensas em seus territórios começaram a sofrer pressões por organismos internacionais, públicos e privados, em especial de ONGs, como Greenpeace e WWF.

Esses mesmos organismos, em um trabalho dificultoso, começaram a disseminar a cultura de como produzir produtos ou serviços com o mínimo de interferência possível no meio ambiente e que gerassem menos problemas (externalidades) para a sociedade. As políticas financeiras em vários países começaram a sofrer mutações com o intuito de forçar as empresas a efetuar planejamentos mais ambientalmente responsáveis. As legislações, licitações e projetos elaborados pelos governos começaram a indicar a necessidade de se atender ao desenvolvimento com o cuidado necessário para que os problemas fossem amenizados.

No Brasil, algumas leis fazem expressa menção à necessidade do desenvolvimento seguir um modelo de auto-sustentabilidade, é o caso da Política Nacional para a Aquicultura e Pesca, que em seu primeiro artigo já menciona a necessidade de se adaptar a produção ou pesca de forma a preservar o bem que está sendo retirado da natureza ${ }^{195}$. Esse tipo de política tem direcionado comunidades de pescadores a formatar cooperativas que têm levado a um bom aproveitamento das águas e melhor comercialização dos produtos obtidos.

Muitos dos princípios de Direito Internacional do Meio Ambiente, por meio de políticas públicas, têm alcançado várias empresas, em especial nos países cuja política têm

\footnotetext{
194 LIMA, L. F. A moldura regulatória internacional do mecanismo de desenolvimento limpo do protocolo de Quioto. 2003. 349 p. Dissertação (Mestrado). Faculdade de Direito da Universidade de São Paulo, São Paulo, 2003.

${ }^{195}$ Lei 11959/2009, Art. $1^{\text {o }}$ "Esta Lei dispõe sobre a Política Nacional de Desenvolvimento Sustentável da Aquicultura e da Pesca, formulada, coordenada e executada com o objetivo de promover: I - o desenvolvimento sustentável da pesca e da aquicultura como fonte de alimentação, emprego, renda e lazer, garantindo-se o uso sustentável dos recursos pesqueiros, bem como a otimização dos benefícios econômicos decorrentes, em harmonia com a preservação e a conservação do meio ambiente e da biodiversidade; II - o ordenamento, o fomento e a fiscalização da atividade pesqueira; III - a preservação, a conservação e a recuperação dos recursos pesqueiros e dos ecossistemas aquáticos; IV - o desenvolvimento socioeconômico, cultural e profissional dos que exercem a atividade pesqueira, bem como de suas comunidades". BRASIL. Lei
} 
sido de melhorar a qualidade de vida da população, bem como conservar os bens da natureza para as próximas gerações. Nesses Estados, as empresas transnacionais absorvem as políticas públicas e, conseqüentemente, as diretrizes do Direito Internacional do Meio Ambiente de forma mais contundente, uma vez que estão afetas às sanções cabíveis.

Nos países cujo desenvolvimento de leis sobre o assunto é mais precário, algumas empresas, cientes do compromisso que têm com seus shareholders, têm buscado pautar suas ações em virtude de dois quesitos fundamentais: a governança corporativa, com o intuito de dar maior transparência e força às suas ações, e o respeito ao meio ambiente, evitando encontrar-se em situações desfavoráveis que possam expô-la de forma negativa, principalmente perante seus consumidores - a maior parte deles encontra-se nos países mais desenvolvidos e possuem uma preocupação ambiental melhor presente e assentada.

Nessa situação, e nem sempre com os limites bem definidos por legislações próprias dos países em que atuam, algumas empresas estão se adaptando aos princípios e regramentos que o Direito Internacional do Meio Ambiente tem desenvolvido. Uma atuação seguindo diretrizes de um conjunto de países, como no caso das Nações Unidas, demonstra uma preocupação que perpassa os domínios do local onde se encontra a empresa matriz e harmoniza uma linha de atuação que deve ser levada a todos os lugares de atuação da empresa.

Com os princípios devidamente expostos, a necessidade e os meios possíveis de se internalizar as externalidades negativas, a aplicação das normas e princípios do Direito Internacional do Meio Ambiente pela empresa é algo plausível e em algumas situações totalmente aceitável. Dessa forma, no próximo capítulo encontrar-se-ão alguns exemplos interessantes de absorção de regras e linhas diretivas por empresas, especialmente as transnacionais, o que de forma alguma tem interferido na lucratividade, satisfazendo tanto os shareholders, quanto os stakeholders, e com grande presença das Organizações NãoGovernamentais.

11.959. Brasília. 2009. Disponível em <http://www.planalto.gov.br/ccivil/_Ato2007-




\section{IV - A APLICAÇÃO DAS NORMAS E PRINCÍPIOS DO DIREITO INTERNACIONAL DO MEIO AMBIENTE PELA EMPRESA}

Nos três primeiros capítulos dessa dissertação foram analisados, na sequiência, o Direito Internacional do Meio Ambiente, o Comércio - em especial, a origem e constituição da empresa - e, logo após, um dos princípios basilares da proteção do meio ambiente na seara internacional, o desenvolvimento sustentável.

O objetivo dos três capítulos precedentes foi obter material e solidificar posições que embasem a interelação entre todas as matérias. Nesse sentido, a compilação e melhor entendimento de como essas questões são tratadas ou conceituadas será capaz de permitir uma análise da aplicação dos princípios e normas do Direito Internacional do Meio Ambiente pela empresa.

Dessa forma, será analisada a chegada do tema meio ambiente ao mercado empresarial, a agenda criada para se trabalhar a questão de adequação ou não, os cenários e perspectivas, bem como os modelos de desenvolvimento mais adequados, finalizando com o porquê das empresas estarem adotando princípios ou normas que não lhe sejam cogentes por via normativa jurisdicionada.

\section{1) Mercado}

Por um acaso etimológico, as palavras merci (obrigado) e marché (mercado) têm a mesma origem. Ambas são provenientes do comércio, da troca de mercadorias, onde cada um está à mercê do outro, tanto o consumidor, quanto o fornecedor. Um agradece pelo produto e o outro pelo valor recebido. É assim desde os primórdios da civilização, uma relação bilateral onde a cortesia, o social, sempre foi a meta principal. Nesse sentido, a recuperação da idéia de empresa social e ambientalmente responsável é a consagração de um modelo que sempre existiu, qual seja, o da dupla responsabilidade e respeito por aquilo que se produz e se consome; reabilitando, conforme Alain Etchegoyen, a idéia de que o 
cenário é criador de um elo social, vetor da melhoria da existência humana, instrumento de transformação positiva do planeta e da sociedade ${ }^{196}$.

Os consumidores, cada vez mais seletivos, estão se tornando linearmente mais cidadãos e não apenas clientes. Inúmeros são os exemplos da inversão negativa de consumo daqueles produtos considerados incompatíveis com o respeito ao meio ambiente. Assim, com consumidores mais informados e capazes de buscar um complemento de sentido e de consciência em seus atos de compra, começaram a surgir desdobramentos que alcançaram grandes corporações e, conseqüentemente, o mercado bursátil mundial. O que revelou, segundo Elisabeth Laville, que a verdadeira legitimidade de uma empresa reside não apenas em seu desempenho comercial mas em sua capacidade duradoura de melhorar, através de sua missão, sua produção e seus valores, bem como as condições de existência em seu entorno ${ }^{197}$.

Como exemplo dessa dinâmica, pode-se observar um caso curioso. Existe na Europa uma associação que congrega as empresas mais antigas do mundo, todas com no mínimo duzentos anos. Estas sociedades representam os setores primordiais da economia, como o artesanato em metal, instrumentos musicais, bancos, entre outros. Em geral são empresas familiares e muito interdependentes de um determinado espaço geográfico, e que, por seu trabalho, exportam para todo o mundo. Eles se autodenominam Henoquianos, do personagem bíblico Henoch (ou Enoque), que por ser justo e responsável, não sendo acusado em coisa alguma, foi tomado por Deus, já que não havia mais ninguém tão bom como ele nesse mundo.

Alguns aspectos dos Henoquianos revelam seus caminhos para o desenvolvimento sustentável: o aspecto moral, vez que todos são oriundos de famílias devotas à alguma religião, fortemente ligados a uma certa ética de comportamento que assegura a longevidade; e o aspecto social, onde o trabalho, investimento, autofinanciamento e a remuneração dos empregados se realizam antes do lucro, o que acaba por gerar um círculo virtuoso que privilegia, primeiramente, os ideais da empresa e de sua comunidade a longo prazo, com o interesse precípuo de que cada geração comprometa-se a repassar a empresa após ter preservado e alargado o seu valor. Assim, deve-se entender que a melhoria contínua advém desse comportamento, ou seja, segundo Elisabeth Laville, “a própria

\footnotetext{
${ }^{196}$ LaVILle, E. A Empresa Verde. São Paulo: Õte, 2009, prefácio.

${ }^{197}$ Laville, E. A Empresa Verde. São Paulo: Õte, 2009, p. 23.
} 
expressão desenvolvimento sustentável indica que esta postura é, antes de mais nada, um caminho de progressos pelo qual a empresa avança lentamente" 198 .

As empresas têm se revelado verdadeiros lugares pertinentes de mudança. Seu poderio comercial possui duas facetas: a primeira, onde o poder extremado e desmedido é altamente ofensivo e nocivo para a sociedade; e a segunda, onde esse largo poder traz acoplado uma grande responsabilidade, que anteriormente era apenas reservada às nações ricas do planeta. Essa responsabilidade imputa a observância dos problemas, bem como o dever de tentar evitá-los ou resolvê-los da forma menos danosa possível, utilizando para isso, basicamente, um dos princípios basilares do Direito Ambiental, o princípio da precaução.

Historicamente, o princípio da precaução surgiu no Direito Internacional do Meio Ambiente a partir das Convenções de Viena para a proteção da camada de ozônio, em 1985; de Oslo para a prevenção da poluição marinha, em 1992; e de Montreal sobre a biossegurança e os transgênicos, em 2000. Sua melhor definição está contida no sumário da Declaração sobre Meio Ambiente e Desenvolvimento, Cúpula da Terra, realizada no Rio de Janeiro em 1992: "Com a finalidade de proteger o meio ambiente, medidas de precaução devem ser extensamente aplicadas. No caso de haver risco de danos graves, irreversíveis, a ausência de absoluta certeza científica não deve servir de pretexto para adiar a adoção de medidas efetivas visando à prevenção da degradação do meio ambiente" 199 .

No que concerne ao universo empresarial, o princípio da precaução está intimamente ligado ao diálogo com os stakeholders ou "partes interessadas". Para poder exercer o seu direito simbólico à atividade, os grupos econômicos devem permanentemente ser capazes de responder por seus atos e impactos, não somente perante seus acionistas, stockholders ou shareholders, mas igualmente diante do conjunto de públicos que, de uma forma ou de outra, é afetado por sua atividade. Assim, o termo stakeholders abrange tanto o conjunto dos grupos que são afetados pelas atividades da empresa como, inversamente, o dos que podem afetar essa atividade. A forma de detalhamento dos stakeholders varia

${ }^{198}$ Laville, E. A Empresa Verde. São Paulo: Õte, 2009, p. 24.

${ }^{199}$ Laville, E. A Empresa Verde. São Paulo: Õte, 2009, p. 25. A distinção entre os princípios da prevenção e precaução também é importante. Segundo Paulo Machado, havendo certeza do dano ambiental, este deverá ser prevenido, tal como preconiza o princípio da prevenção. Ao existir dúvidas ou incertezas também deverá haver diligência no sentido de se agir prevenindo. Essa é a premissa do princípio da precaução. A incerteza científica, demonstrada com expressões razoáveis, não gera a dispensa da prevenção. Assim, pode-se concluir que o princípio da prevenção tem lugar para evitar danos que são, ou poderiam ser sabidos; enquanto o da precaução atua quando não há certeza científica quanto ao dano, no entanto faz permanecer o dever de evitá-lo. Machado, P. A. L. Direito Ambiental Brasileiro. São Paulo: Malheiros, 2001, p. 55. 
conforme a atuação da empresa e seu setor: ao se imaginar uma empresa concessionária de serviço público, suas partes interessadas serão compostas por sua administração e as comunidades com as quais trabalha.

A empresa preocupada em identificar suas partes interessadas demonstra importante avanço na via do desenvolvimento sustentável, uma vez que tem consciência de que a uniformização de pontos de vista infere diretamente na sua reputação e crescimento em longo prazo. A empresa responsável concentra-se em desenvolver e aprimorar com todos os seus públicos um diálogo real, transparente e honesto, já que essa é uma maneira ímpar de merecer e manter a confiança renovada desses públicos.

Cada vez mais as empresas reconhecem que sozinhas não serão capazes de encontrar todas as respostas. Para melhorar a comunicação elas devem estender o diálogo às mais variadas esferas, bem como efetivar realmente esse contato, já que algumas corporações preferem atuar na forma de monólogo, sem somar novas vozes e pensamentos, com o intuito único de fazer prevalecer a sua forma de atuação em determinado setor. Essa comunicação unilateral gera, efetivamente, apenas o fechamento do grupo econômico em torno de si mesmo. Ao se desligar das preocupações de seu público e da evolução de seus ambientes, a empresa teria muito menos chances de antecipar os desafios emergentes para sua atividade e de prevenir os riscos ${ }^{200}$.

Essas informações sobre partes interessadas, diálogo e estudo estão diretamente relacionadas com a boa governança, uma vez que prestar contas sobre a forma como as decisões são tomadas nos órgãos executivos da empresa é exatamente um grande desafio. Esse conceito é frequentemente utilizado quando se trata da ética ou responsabilidade empresarial.

Basicamente, a expressão refere-se às normas que regem a administração das empresas e, principalmente, à responsabilidade de seus executivos face aos acionistas, em desafios ligados à maneira como seus interesses são levados em consideração nas políticas e decisões empresariais. Os recentes escândalos de grandes empresas como a Parmalat, Enron ou Vivendi restaram evidente que a confiança dos acionistas na capacidade dos dirigentes de defender seus interesses em longo prazo não é plena. Dessa forma, novas legislações surgiram para precisar o que se espera das empresas nesse quesito, como os

\footnotetext{
${ }^{200}$ Tal situação ocorreu com as empresas da indústria cosmética que, por anos, não perceberam a crescente preocupação com os testes realizados em animais e tiveram que, imediatamente, a um custo elevado, adaptarse a essa nova exigência da sociedade.
} 
relatórios Viénot e Bouton, na França, ou Sarbanes-Oxley Act, nos Estados Unidos da América $^{201}$.

O enfoque é garantir que os administradores sirvam aos interesses da corporação sem aterem-se apenas ao valor a curto prazo de suas ações. Assim, acionistas e investidores têm interesse na atenção de temas como: comitês de gestão remuneratória ou de verificação de contas; administradores independentes nos conselhos de administração, executivo e fiscal; auditores que não atuem apenas como prestadores de serviços bem remunerados; e a implicação efetiva dos administradores nas decisões tomadas pela empresa (reuniões, estudos, consultas, participação, comunicação interna e externa, entre outros meios).

No que concerne ao desenvolvimento sustentável, a idéia de governança vai, portanto, além da capacidade dos dirigentes de levar em conta os interesses dos investidores em sua forma de administrar o empreendimento, e engloba também sua capacidade de levar em consideração os interesses das outras partes envolvidas. Dessa forma, pode-se observar a chegada aos altos escalões decisórios de assuntos que eram tratados de forma simplificada em alçadas inferiores ou por muitas vezes sequer eram discutidos. No quesito meio ambiente, algumas empresas conscientes já nomearam indivíduos independentes, responsáveis por fazer valer esse tema nas discussões. O mote é minimizar o fato de que certas partes interessadas da empresa, afetadas por suas decisões, não estejam representadas nos conselhos decisórios.

Embora a prova da degradação ambiental fique cada vez mais clara e ainda que existam atualmente mais de quinhentos acordos ambientais multilaterais, a capacidade política dos Estados para fortalecer a ação e implementação destes acordos parece ser cada vez menor, especialmente durante reveses econômicos, quando a filosofia do "salve-se quem puder" prepondera e os Estados preocupam-se apenas em gerar estímulos em uma economia, na maioria das vezes, baseada na degradação do meio ambiente.

Por várias décadas, governos e analistas vêm identificando alguns problemas do sistema ambiental da Organização das Nações Unidas (ONU), que se traduzem pela ausência de coerência, eficiência, informação adequada, equidade e financiamento adequado. No mesmo compasso, surge a idéia de que a magnitude e a complexidade dos problemas ambientais globais ultrapassam a capacidade das instituições existentes.

\footnotetext{
201 Ambas são normas que delimitam a governança corporativa e dimensionam como devem ser tratados eticamente alguns temas do mundo empresarial.
} 
Uma das razões para este cenário pode ser identificada na complexa fragmentação da governança ambiental internacional, demonstrando múltiplas atribuições e papéis, distribuídos em instituições de várias esferas e segmentos, e a falta de coordenação entre elas. Geralmente os acordos ambientais não possuem metas claras que viabilizem e facilitem a implementação dos mesmos, e os países em desenvolvimento sofrem com as altas metas para cumprir com os compromissos firmados em relatórios de implementação e até mesmo com a garantia de participação nas conferências e reuniões de negociação sobre os acordos. Esse ponto de crítica, anteriormente indicado nesta dissertação, pode ser mitigado pela dificuldade existente nas negociações internacionais, pois, com o intuito de não ver um impasse, os pontos comuns, e geralmente mais amplos, são aprovados sem um verdadeiro senso de proficuidade.

Dentre as dificuldades existentes encontra-se o enfoque inadequado dos impactos ambientais globais provocados pela globalização econômica, como, por exemplo, a fragmentação normativa, a existência de mandatos e acordos que seguem uma lógica setorial para a gestão ambiental, alguns mecanismos de arbitragens fracos e a falta de visão holística sobre a governança ambiental internacional. Politicamente, constatam-se discrepâncias entre compromisso e ação, bem como a falta de um apoio político forte, o que tem contribuído para o fracasso de integrar efetivamente o meio ambiente na arena macroeconômica. Atualmente, inexiste um ou mais países de grande poder que se utilizem da proteção do meio ambiente como foco permanente de sua política pública ou internacional.

Assim, o desafio é montar e desenvolver condições de governança, local e global, utilizando-se inclusive dos regimes multilaterais, de instrumentos de comando-controle, ou seja, associados ao Poder Público regulamentador e administrador de interesses de toda a comunidade, e de instrumentos econômicos, por meio dos quais o mercado e as empresas assumem os custos ambientais e sociais de suas respectivas atividades.

Assim, a análise da sistemática atual e a possível evolução da governança ambiental global de algumas situações, por exemplo, o caso de mudanças climáticas, devem ser realizadas considerando também a abordagem sistêmica no modelo de regimes internacionais. O estudo da seara internacional interveniente, isto é, o uso de uma abordagem analítica aplicada aos mecanismos de contratação inter e transnacional, pode auxiliar tanto o entendimento como a efetividade dos mesmos, como a construção dos mecanismos e condições de governança, no viés da cidadania mundial. 


\section{2) Instituições}

Considera-se que, genericamente, regimes são instituições sociais organizando as ações daqueles envolvidos em um conjunto de labores específicos. São constituídos de procedimentos e práticas, abrangendo regras e papéis a serem desempenhados e aplicados pelos próprios indivíduos que atuam nessa seara. Um regime é aquele composto por um sistema de normas e regras especificadas em um termo multilateral formal e legal entre Estados para regular as atividades no tocante a um determinado problema.

Dessa forma um regime poderá se materializar a partir de um ou mais instrumentos legais, tais como um tratado ou convenção. Isto definiria os princípios, objetivos e normas gerais, contendo ou não compromissos obrigatórios mais específicos, que em geral são negociados e pormenorizados em documentos legais posteriores, conhecidos, normalmente, como protocolos. Pode-se, também, contemplar como regimes alguns acordos não explicitados em um instrumento legal, posto que muitas vezes, ou quase sempre, os regimes são constituídos a partir de arranjos informais, administrativos e/ou políticos, e apenas a partir de certo ponto tomam a feição de um tratado ou outra forma legalmente vinculante. Dessa maneira, mantém-se a perspectiva e influência histórica na análise do regime e a possibilidade de construção e fortalecimento de condições de governança, nas searas nacional e global, ao longo da evolução do regime.

Em virtude da multilateralização e da globalização das relações internacionais, observa-se um número crescente de iniciativas de regulamentação internacional em assuntos como meio ambiente, desarmamento, segurança, saúde, direitos humanos, resíduos e substâncias perigosas. Em função dos eventos de setembro de 2001, as guerras no Afeganistão e Iraque, atentados em Londres e Madrid, entre outros, o tema da segurança foi mais bem tratado pelos Estados. Ao se comparar com outros regimes como os de comércio, saúde ou política econômica, o conjunto de suporte para o regime do meio ambiente carece de articulação e coerência.

Uma primeira questão, debatida há muito tempo, é se os desafios e responsabilidades ambientais deveriam estar organizados no âmbito da uma única instituição, que fosse ágil e eficiente, de respaldo internacional, vinculada ao sistema da Organização das Nações Unidas, ou se, os regimes multilaterais ambientais podem cumprir seus objetivos a partir de esquemas fragmentados. Por alguns anos, as responsabilidades 
ambientais, ao invés de se consolidarem dentro do PNUMA, têm se diversificado por meio de muitas organizações, incluindo, as agências especializadas da ONU, como a Organização Mundial de Meteorologia, a UNESCO, a FAO e tantas outras; os programas da ONU como o PNUD e o Programa Mundial de Alimentação; as comissões econômicas e sociais regionais da ONU; as instituições de Bretton Woods (como o Banco Mundial e o Fundo Monetário Internacional); a Organização Mundial de Comércio; e o Fundo Global para o Meio Ambiente (GEF). Uma fragmentação desse tipo resulta em sobreposições, brechas e dificuldades do sistema em responder a problemas ambientais globais.

Maria Ivanova apresenta pontos encontrados em estudos que defendem a multiplicidade de programas e organizações na governança ambiental internacional através de uma sobreposição produtiva, criando um tipo de multilateralismo competitivo que melhoraria a eficiência das atividades. Porém, argumenta que a competição e redundância podem ser desnecessárias e provocar prejuízos. Podem até existir resultados diferentes entre as atividades e incongruências com o Direito Internacional. Os exemplos seriam os organismos geneticamente modificados que são tratados com regulamentos bem mais rigorosos na Convenção da Diversidade Biológica do que na Organização Mundial do Comércio $^{202}$.

No mesmo artigo, Maria Ivanova apresenta a organização da governança ambiental global, usando como exemplo as atividades ambientais em 12 áreas (poluição atmosférica, agricultura, biodiversidade, químicos, mudanças climáticas, desertificação, energia, pesca, florestas, espécies invasoras, comércio de espécies ameaçadas e água) nas quais atuam os 44 membros do Grupo de Gestão Ambiental, que foi criado, em 1999, para desenvolver a coordenação das políticas ambientais na ONU. O resultado deste trabalho mostra uma grande complexidade, com 26 organizações ativas no âmbito de mudanças climáticas, 29 em químicos e 31 em água. No Brasil, ao observar-se a gestão de águas, os comitês de bacia hidrográfica reúnem dezenas de instituições e segmentos governamentais, privados e da sociedade que de alguma forma atuam ou são relevantes para se exercer a conservação e uso sustentável dos recursos hídricos.

Ao mesmo tempo, as atividades de cada área são organizadas a partir de diferentes locais no planeta, o que gera dificuldades de comunicação e coordenação. No caso da água, o PNUMA organiza de Nairóbi, a UNESCO de Paris, a Organização Mundial de Meteorologia de Genebra e o GEF de Washington. A depender do assunto, as organizações

\footnotetext{
${ }^{202}$ Esty, C. D.; Ivanova, M. H. Governança Ambiental Global. Opções \& Oportunidades. São Paulo:
} Editora SENAC, 2005. 
atuantes podem ter objetivos e visões divergentes. Ao utilizar o caso dos químicos, por exemplo, a Organização Mundial da Saúde se preocupa com o impacto de químicos sobre a saúde humana, a Organização para a Cooperação e Desenvolvimento Econômico (OCDE) tem interesse em desenvolver atividades de saúde e segurança ambiental, a Organização Internacional do Trabalho pretende proteger os direitos dos trabalhadores na indústria química e a Organização Internacional Marítima tem como meta prevenir a chegada de resíduos químicos nos mares e oceanos.

De início, não parece problemático que inúmeras organizações atuem no campo ambiental. O problema se avoluma quando não existem meios eficientes de coordenação, de troca de dados e de governança ou controle social, especialmente nos casos, ainda presentes, de adoção, por diferentes áreas governamentais e privadas, de políticas contraditórias quanto à sustentabilidade social e ambiental. Desta forma, podem ser necessárias a delimitação de metas comuns e ações com claros objetivos dentro do sistema das Nações Unidas, criando sinergia e convergência nas ações e resultados de tais acordos.

Para tanto, também seria importante compreender os papéis, as responsabilidades e os recursos dos agentes principais na organização da governança ambiental internacional: as organizações e as convenções ambientais internacionais, os bancos e organizações de desenvolvimento e outras agências do sistema ONU, bem como as organizações da sociedade civil.

O sistema da ONU tem se mostrado pouco efetivo na implementação plena de Acordos Ambientais Multilaterais, quando comparado com outros regimes e instituições multilaterais. Muitos países desenvolvidos, em vez de cumprir as metas e acordos assumidos na Declaração do Rio de Janeiro (1992), na Agenda 21 e em outros Acordos Ambientais Multilaterais, vêm dando ênfase a agenda da Organização Mundial do Comércio (OMC), que tem um forte mecanismo de cumprimento e promove um regime de regras que são, em sua maioria, contrárias ao espírito e aos princípios da RIO $92^{203}$.

A rejeição unilateral de acordos, como o Protocolo de Quioto, por alguns Estados, representa outro risco aos trabalhos necessários para avançar na evolução do desenvolvimento sustentável. As Declarações sobre o Ambiente Humano (Estocolmo 1972) e sobre Meio Ambiente e Desenvolvimento (RIO 1992), bem como a Agenda 21, embora não sejam juridicamente vinculantes, refletem ações e atitudes que, espera-se,

${ }^{203}$ FALK, R. Globalização Predatória. Uma crítica. Tradução Rogério Alves. Lisboa: Instituto Piaget, 1999, p. 54. 
sejam cumpridas pelos Estados e pela sociedade. Dessa forma, devem fazer parte da análise e da atenção da governança ambiental global.

\section{3) Agenda ambiental global}

Existe uma agenda definida das principais preocupações da comunidade internacional em relação ao meio ambiente. Ao dar seguimento a essa agenda tem havido uma profusão de conferências, negociações, planos de ação, tratados e outras iniciativas de caráter internacional. Novos campos do Direito e da diplomacia ambiental surgiram, assim como uma vasta produção de importantes pesquisas científicas e de análises políticas. A comunidade internacional ligada ao meio ambiente e várias ONGs têm executado ações cada vez mais sofisticadas, indo do global ao local, da desobediência civil às publicações editadas por grupos de especialistas.

Tanto governos nacionais, quanto instituições multilaterais, da Organização das Nações Unidas (ONU) aos bancos de desenvolvimento internacional, vêm congregando tais preocupações e criando importantes unidades voltadas para tratar de questões ambientais de escala global. No mesmo sentido, enquanto algumas empresas transnacionais ainda se mostram reticentes, outras se tornaram fortemente inovadoras, dando passos importantes, muitas vezes antes de seus governos. Nos meios acadêmicos, as questões do meio ambiente internacional tornaram-se um dos principais assuntos de indagação intelectual e de ensino. As preocupações ambientais, por vultuosas, têm despertado cada vez mais atenção de governos, ONGs, agências multilaterais e da comunidade empresarial. Assim, é necessário observar como surgiu essa agenda, quais questões foram identificadas e enquadradas e o que se conseguiu até o presente momento no campo da governança ambiental global.

Os anos 1960 marcam o início da "Era Moderna" das preocupações ambientalistas. De início, elas se resumiam a aspectos domésticos, sobretudo locais: poluição do ar e da água, mineração de superfície, construção de rodovias, poluição sonora, canalização de represas e córregos, desflorestamento, disposição de resíduos contaminados, usinas nucleares, exposição a substâncias tóxicas, vazamentos de petróleo, crescimento suburbano. Foi nesse período que a preocupação com essas questões ganhou força. 
Nos Estados Unidos da América, por exemplo, tais preocupações levaram à aprovação da Lei Federal de Política Ambiental, em dezembro de 1969, e ao primeiro Dia da Terra ${ }^{204}$, alguns meses mais tarde. Em poucos anos, no começo da década de 1970, criaram-se, naquele país, a Agência de Proteção Ambiental e o Conselho Presidencial sobre Qualidade Ambiental, aprovaram-se o Código de Qualidade da Água e do Ar e outras importantes leis federais, e os tribunais federais ficaram repletos de processos impetrados por uma nova geração de organizações de defesa ambiental, normalmente patrocinadas por grandes fundações estadunidenses. Foi durante essa época que se criaram grupos como o Conselho de Defesa dos Recursos Naturais e o Fundo de Defesa Ambiental $^{205}$.

Para isso acontecer, alguns fatores se conjugaram. Primeiro, houve uma crescente necessidade de qualidade ambiental, advinda de uma população do pós-guerra cada vez mais afluente. Entre os anos de 1950 e 1970, a renda per capita nos Estados Unidos da América aumentou em torno de $52 \%$. A população passou a buscar as amenidades dos subúrbios, e por volta de 1970 havia mais estadunidenses vivendo nas áreas suburbanas ou rurais. A visitação aos parques nacionais dobrou entre 1954 e 1962, e dobrou novamente por volta de 1971.

Segundo fator, a poluição e a deterioração eram flagrantes e inevitáveis. Smog (neblina e fumaça), fuligem, o ardor nos olhos e a tosse causados pela poluição atmosférica, rios e praias fechados à pesca e ao nado devido à contaminação da água, lixo plástico e substâncias tóxicas que não se dissipavam, pássaros ameaçados pelo DDT, envenenamento por pesticidas, mortandade de peixes, usinas de força e rodovias em áreas residenciais, pântanos aterrados para a construção de casas e córregos canalizados para navegação e drenagem; todas essas ameaças eram latentes e não podiam ser ignoradas.

Um terceiro fator, a ascensão social dos anos 1960 fizera surgir uma nova classe de jovens contestadores, politicamente ativos e socialmente engajados. Os movimentos pelos Direitos Civis e contra a guerra espelharam que o ativismo político podia dar resultado. Alguns dos ativistas não eram tão jovens. Tomando como exemplo os protestos (seat-ins) contra a Guerra do Vietnã, o senador Gaylord Nelson, de Wisconsin (EUA), surgiu com a

\footnotetext{
${ }^{204}$ O Dia da Terra foi criado em 1970 quando o Senador estadunidense Gaylord Nelson convocou o primeiro protesto nacional contra a poluição. O dia é festejado em 22 de abril e a partir de 1990, outros países passaram a celebrar a data.

${ }^{205} \mathrm{O}$ novo movimento ambientalista infligiu uma longa série de derrotas à comunidade empresarial, deixando os cientistas ansiosos em seus esforços para manter o ritmo. Os economistas ficaram consternados, e os ecologistas - e mesmo os advogados - viraram celebridades. Parcelas majoritárias da população cerraram
} 
idéia de um protesto nacional em favor do meio ambiente, e dessa maneira deu início ao que se transformou no primeiro Dia da Terra.

Quarto fator, havia uma opinião generalizada de que as grandes empresas estavam se safando de seus crimes, razão pela qual Ralph Nader e Rachel Carson, escritores eloquentes, escreveram obras explicitando os horrores da guerra corporativa ${ }^{206}$.

Como quinto fator, deve-se considerar que o provável adversário, a comunidade empresarial, foi pego de surpresa, sem tempo de se organizar nem de obter estudos favoráveis aos seus trabalhos. Até mesmo as ONGs ligadas ao meio ambiente foram surpreendidas.

Por fim, alguns grandes eventos aconteceram como: o rio Cuyahoga, em Cleveland (EUA), "pegando fogo"207; a proposta do Departamento do Interior de "inundar" o Grand Canyon (EUA); e, ainda mais significativo, o vazamento de petróleo em Santa Bárbara, em $1969^{208}$.

\subsection{1) As questões globais}

Sendo essa cena doméstica estadunidense a mais conhecida, onde estavam os temas mundiais preocupantes? Tal como a agenda doméstica dos anos 1970 se constituiu, em sua maioria, na década precedente, a agenda global de mudanças foi vagarosamente se formando nos anos 1970. Durante essa década, apareceu um fluxo constante de publicações com uma perspectiva mundial, chamando a atenção para as questões de escala

fileiras pelo meio ambiente. Os meios de comunicação encheram-se de histórias e curiosidades, e o governo reagiu impondo exigências custosas e de grande alcance e rigorosos prazos a indústria.

${ }^{206}$ Ralph Nader escreveu Unsafe at Any Speed, em 1965, e Rachel Carson publicou Silent Spring, em 1962.

${ }^{207}$ Nesse rio, que atravessa o Estado de Cleveland, nos Estados Unidos da América, dejetos derivados do petróleo eram lançados ao seu leito, ocasião em que um incêndio de grandes proporções ocorreu no ano de 1969.

${ }^{208}$ Os desafios em escala global que atualmente preocupam a todos estavam quase totalmente ausentes das discussões nos anos 1960 e 1970. Somente o aumento populacional da terra e a proteção da camada de ozônio faziam parte dos interesses ambientais da época. Não havia qualquer discussão científica, nem grupo de cientistas, observando tais questões adiante. Alguns especialistas desempenharam, individualmente, importantes papéis; Paul Ehrlich, John Holden, Barry Commoner e George Woodwell, entre outros. No entanto, os temas precipitaram-se, sobretudo, em virtude de determinados acontecimentos e à realidade das experiências cotidiana das pessoas. Havia pouca necessidade de tentar definir e promover uma agenda. Esta ia se definindo nos incidentes rotineiros e na sequência de ações executadas como resposta. Foi Lois Gibbs, não os cientistas nem o governo, que, com seus esforços no Love Canal, por exemplo, colocou em pauta a questão dos depósitos de lixo contaminado, e isso aconteceu depois que boa parte das primeiras leis ambientais já haviam sido promulgadas. 
global $^{209}$. Muitas foram descritas por especialistas que visavam levar suas descobertas - e as de seus colegas - a um público mais amplo. Alguns desses estudos foram inovadores e definiram a agenda ambiental global, porém nem todos tiveram aceitação universal ${ }^{210}$.

Numerosos trabalhos também foram produzidos por grupos científicos, sobretudo painéis e comissões, organizados pelo Conselho Internacional para a Ciência (ICSU), pela U.S. National Academy of Sciences, pela União Mundial pela Conservação da Natureza (IUCN) e pelo Programa das Nações Unidas para o Meio Ambiente (PNUMA). Dentre esses estudos, havia o trabalho de 1974, agora famoso, feito por Rowland e Molina, no qual os autores demonstravam o potencial que os clorofluorcarbonetos (CFCs) têm de destruir a camada de ozônio. O trabalho de ambos foi a primeira pesquisa ambiental a ganhar o Prêmio Nobel. Dentre esses estudos, havia também o Charney Report, publicado pela U.S. National Academy of Sciences em 1979, trabalho esse que expôs quase tudo o que se poderia saber sobre mudança climática, a fim de iniciarem-se determinadas ações. Esses trabalhos e outros de Lester Brown e equipe, no Worldwatch Institute, estabeleceram, coletivamente, os principais tópicos. Assim, a partir de 1980, uma série de estudos foi publicada, buscando reunir todos esses temas em uma agenda coerente com vista a ações de amplitude internacional ${ }^{211}$.

Muitos esforços científicos foram realizados com o afã de despertar a atenção dos governos para os desafios de amplitude global. Esses trabalhos, segundo James Gustave Speth, "destacavam coletivamente dez preocupações fundamentais sobre o meio ambiente: perda de terras para a agricultura e pastagem causada por desertificação, erosão, conversão para usos não-agrícolas e outros fatores; destruição das florestas tropicais do mundo, com a conseqüente perda de recursos florestais, sérios danos a bacias hidrográficas (erosão, inundação e sedimentação) e outras conseqüências adversas; extinção em massa de espécies, principalmente com a perda global de habitat selvagem e a conseqüente perda de

\footnotetext{
${ }^{209}$ FALK, R. Globalização Predatória. Uma crítica. Tradução Rogério Alves. Lisboa: Instituto Piaget, 1999, p. 40/41.

${ }^{210}$ Trabalhos seminais sobre o meio ambiente global - 1970/1978. 1970 - Man's impact $n$ the Global Environment, relatório do estudo sobre os problemas críticos do meio ambiente (grupo científico reunido no Massachusetts Institute of Technology; 1971 - This endangered Planet, Richard Falk; 1972 - Exploring New Ethics for Survival, Garret Hardin; 1972 - Only One Earth, Barbara Ward e Rene Dubos; 1974 - The Limits to Growth, Donella Meadows et al.; 1978 - The Human Future Revisited, Harrison Brown; 1978 - The Twenty-Ninth Day, Lester Brown.

${ }^{211}$ Trabalhos seminais sobre o meio ambiente global - 1980/1990. 1980 - World Conservation Strategy, IUCN e Pnuma; 1980 - the Global 2000 Report to the President, U.S. Council on Environmental Quality; 1981 - Global Future: Time to Act, U.S. Council on Environmental Quality; 1982 - The World Environment: 1972-1982, grupo científico do Pnuma; 1983 - Environmental Research and Management Priorities for the 1980's, grupo internacional de cientistas organizado pela Royal Swedish Academy of Sciences; 1987 - Our Common Future, World Commission on Environment and Development, Relatório da Comissão Brundtland.
} 
recursos genéticos; crescimento populacional muito rápido, inflando as cidades do "Terceiro Mundo", e refugiados ecológicos; má administração e escassez de recursos de água doce; pesca predatória, destruição de habitat e poluição do ambiente marinho; ameaças à saúde humana oriundas do mau uso de pesticidas e de poluentes orgânicos persistentes; mudança climática causada pelo aumento dos gases que provocam o efeito estufa na atmosfera; chuva ácida e, mais comumente; os efeitos de uma complexa mistura de poluentes atmosféricos em peixes, florestas e plantações; destruição da camada de ozônio pelos CFCs e por outros gases" ${ }^{\text {212 }}$. Trata-se, claramente, de uma nova agenda, muito distinta daquela que deu origem ao primeiro Dia da Terra, em 1970.

\subsection{2) Cenários}

O cientista político Keith Caldwell observou que foram relevantes dois avanços antes de surgir o movimento ambientalista internacional: a política ambiental teve de ser legitimada domesticamente, e os processos de sustentação da vida da biosfera tiveram de ser percebidos como uma preocupação comum a todas as populações ${ }^{213}$. Caldwell vê a Conferência das Nações sobre Ambiente Humano (a Conferência de Estocolmo de 1972) como ponto focal para o desenvolvimento de programas ambientais domésticos, incluindo os da Europa, que estavam atrasados em relação aos Estados Unidos naquele momento, embora não mais o estejam; além disso, ela legitimou a biosfera como um objeto de política nacional e internacional e de gerenciamento coletivo.

Outra importante consequência da Conferência de Estocolmo foi a criação do PNUMA, que, tal como foi possível observar, teve um papel de destaque na formulação da agenda global nos anos 1970. O PNUMA, segundo Speth, "fez estimativas de desflorestamento e promoveu estratégias de ação, organizou a conferência internacional sobre desertificação, em 1977, e promoveu acordos internacionais para proteção de

${ }^{212}$ SPETH, J. G. A agenda ambiental global: origens e perspectivas In: EsTY, C. D.; IvanOVA, M. H. Governança Ambiental Global. Opções \& Oportunidades. São Paulo: Editora SENAC, 2005, p. $26-27$.

${ }^{213}$ Caldwell, L. K. International Environmental Policy: From the Twentieth to the Twenty-First Century. 3 ed. Durham: Duke University Press, 1996. 
espécies migratórias e o Programa sobre o Clima Mundial da Organização Mundial de Meteorologia, tudo nessa década"214.

Em meados dos anos 1980, a liderança intelectual e política da comunidade científica, da comunidade de ONGs (como IUCN, Worldwatch e Instituto Mundial de Recursos - WRI) e do PNUMA haviam colhido êxitos: uma nova agenda ambiental internacional fora estabelecida, uma agenda que os Estados teriam de enfrentar coletivamente, de alguma forma, se quisessem ter credibilidade. A pressão para que essas questões fossem postas em prática era alta demais para ser deixada à parte. Estudiosos da comunidade científica e das ONGs tinham, e ainda têm, pleno acesso à mídia para continuar pressionando e mantendo as questões à vista do público.

Ainda levaria mais uma década para que isso acontecesse integralmente, mas, em meados dos anos 1990, cada um dos desafios tinha se tornado tema de algum importante tratado internacional, plano de ação ou outra iniciativa ${ }^{215}$. Assim, o que se observa é que a agenda global surgiu e avançou devido, especialmente, a uma comunidade internacional e às relativamente pequenas lideranças na ciência, no governo, na ONU e nas ONGs. Essas lideranças criaram oportunidades para fazer avançar tais questões, de tal forma que os Estados não tiveram outra escolha senão responder. O jogo de muitos governos era reagir, mas não obrigatoriamente.

\subsection{3) Ação doméstica e indiferença global}

Ao se utilizar tal cenário como pano de fundo, é instrutivo comparar o surgimento da agenda global com a emergência predominantemente doméstica de uma década antes. As diferenças mostraram-se interessantes para que os governos fizessem correções de caminho. As questões da agenda doméstica eram especializadas, imediatas e compreensíveis ao público. As questões da agenda global tendem a ser mais complexas, mais remotas (pelo menos na perspectiva dos países desenvolvidos), tecnicamente complicadas e, portanto, mais difíceis de entender e aglutinar. Esses desequilíbrios

\footnotetext{
${ }^{214}$ Speth, J. G. A agenda ambiental global: origens e perspectivas. In: Esty, C. D.; IvANOvA, M. H. Governança Ambiental Global. Opções \& Oportunidades. São Paulo: Editora SENAC, 2005, p. 28.

${ }^{215}$ Embora as iniciativas envolvendo rios e mares sejam frágeis demais para serem levadas em conta.
} 
traduziram-se em grandes diferenças no que diz respeito ao grau de consciência e de apoio da opinião pública.

A agenda global não foi criada de baixo para cima, a partir de impactos reais sobre as pessoas; foi, ao contrário, forjada de cima para baixo, em nível internacional, pela ciência, por ONGs e por uma agência da ONU em Nairóbi. Diferentemente da agenda doméstica, o respeito pela soberania nacional requer acordos entre vários Estados, amiúde com diferentes escalas de prioridades. Nenhum governo pode ser compelido nem obrigado a concordar. Assim, é difícil conseguir convenções e tratados, e os obrigatórios então, são muito raros. Além disso, as agendas internas podem ser implementadas mediante nova legislação, mas a agenda global exige dos Estados grandes despesas, inclusive assistência financeira aos países menos desenvolvidos.

A agenda doméstica foi, felizmente, regulada juridicamente, antes que houvesse oposição de empresas e de outros setores. Já as ações pertinentes à agenda global foram intentadas contra uma oposição alerta, preparada e poderosa, pois as empresas sentiram, à época, seus interesses ameaçados. Os Estados Unidos da América esteve na liderança, nos anos 1970, quando a agenda doméstica exigiu medidas concretas, mas não tem exercido a mesma liderança no que diz respeito à agenda global. Na verdade, os Estados Unidos da América têm sido amiúde um dos principais óbices nos acordos internacionais sobre o meio ambiente.

Ademais, para Speth, o vilão da agenda global é mais disseminado: "A culpa pelos problemas ambientais do planeta não pode ser exclusivamente imputada às grandes corporações, uma vez que os estilos de vida nos países desenvolvidos, a má administração de governos e outras causas perfazem um conjunto complexo de fatores. Cada vez mais, a poluição não é a conseqüência de algo que vai mal, porém o resultado da vida normal"216.

Considerando as tamanhas barreiras ao progresso, é um grande feito que algo tenha sido realizado. Conforme observado anteriormente, há um rol significativo de realizações que se seguiram ao surgimento da nova agenda global. No entanto, como também se observou, tem havido sérios obstáculos na busca por ações internacionais concretas e $\operatorname{conjuntas}^{217}$.

${ }^{216}$ SPETH, J. G. A agenda ambiental global: origens e perspectivas. In: Esty, C. D.; Ivanova, M. H. Govenança Ambiental Global. Opções \& Oportunidades. São Paulo: Editora SENAC, 2005, p. 30.

${ }^{217}$ Importante indicar o discurso de David Kennedy que expõe a necessidade de uma atuação mais abrangente da Organização das Nações Unidas na aceitação de regras de governança global, supostamente mais condizentes com a realidade e não apenas afeitas aos interesses dos Estados-parte. KENNEDY, D. The Rule of Law at the International Level. In: UN RULE OF LAW UNIT, 2009, Nova Iorque. Rule of Law at the International Level. Nova Iorque: UN, 2009. 
4.3.4) Avaliações dos anos 1960 e 1970

Não se pode apontar, em uma visão retrospectiva, que as gerações dos anos 1960 e 1970 nada fizeram em resposta ao apelo global por novas atitudes. Houve vários progressos em algumas frentes. Há histórias impressionantes de sucesso, mas raramente à altura do problema. De certa forma, trata-se de um período de compreensão dos fatos, causas e consequências $^{218}$. No entanto, se não houve sucesso em reverter essas tendências, talvez tenham sido lançadas as bases para uma rápida ação nos dias atuais. De fato, são desapontadores os resultados de vinte anos de negociações internacionais em torno do meio ambiente. Não que os acordos tenham sido inúteis, por exemplo, sobre mudança climática, desertificação, desenvolvimento sustentável e biodiversidade. Mas essas convenções são, em sua maioria, estruturas para a ação; elas pouco forçam a impulsão das mudanças que se fazem necessárias ${ }^{219}$.

\subsection{5) Quadros}

O Conselho Empresarial Mundial para o Desenvolvimento Sustentável (WBCSD) delineou amplos caminhos para a governança ambiental, projetando três cenários distintos e que dão uma noção exata da atuação de governos, empresas e sociedade civil para com a proteção do meio ambiente.

O cenário "Primeiro Aumente nosso Crescimento" (First Raise Our Growth, Frog) requer, primeiramente, a solução dos desafios econômicos. O Frog é um cenário tipicamente empresarial, que gera enormes custos ambientais, mesmo aos empresários.

${ }^{218}$ FALK, R. Globalização Predatória. Uma crítica. Tradução Rogério Alves. Lisboa: Instituto Piaget, 1999, p. 51.

${ }^{219} \mathrm{O}$ mesmo pode ser apontado a respeito das longas discussões internacionais sobre as florestas do mundo, que nunca chegaram a ser formalizadas legalmente. Normalmente, a legislação ambiental internacional e seus vários tratados estão eivadas de acordos vagos, exigências mínimas, cumprimento e recursos escassos. Entretanto, a fragilidade da grande maioria dos tratados sobre meio ambiente não deveria ser uma surpresa; eles foram criados em processos de negociação que dão um máximo de vantagem a qualquer país interessado em manter o status quo vigente. 
O GEOPolity é um cenário de sucesso, no qual a sustentabilidade é buscada prioritariamente. Dessa forma, os indivíduos voltam-se para o governo, visando direcionar o mercado para fins ambientais e sociais, e ficam em grande medida dependentes de instituições e de tratados intergovernamentais. Tanto o Frog, quanto o GEOPolity são vinculados ao padrão de desenvolvimento, identificado por Richard Falk, como de “globalização descendente". Essa noção diz respeito a uma tentativa de se combater desigualdades a partir da iniciativa normativa de governos e Estados ${ }^{220}$.

O cenário final é o Jazz, embora não seja um acrônimo. É um estado de espírito, um mundo de iniciativas não formalizadas, descentralizado e de improvisação. Nesse cenário, há informações abundantes sobre o comportamento empresarial; a opinião pública e os consumidores cobram boa conduta do mundo dos negócios; os governos facilitam a atuação das partes interessadas; as ONGs são muito ativas; o empresariado vê vantagem estratégica em planejar ações sustentáveis. Nesse caso, a iniciativa normativa segue o padrão de "globalização ascendente" cujo intuito, segundo Richard Falk, é "minimizar a violência, maximizar o bem-estar econômico, fomentar a justiça social e política e preservar a qualidade ambiental" 221 .

Segundo Speth, "a primeira resposta internacional à agenda global de mudanças foi tentar fazer o mundo ir do Frog ao GEOPolity. No entanto, com o passar dos anos percebeu-se que o modelo não possuía o impulso necessário, uma vez que se exigiriam novas medidas com fundamento no apoio mútuo entre os agentes ${ }^{222}$. $\mathrm{O}$ atual quadro do GEOPolity demonstra grande dificuldade em sua efetivação. Ele pode ser redesenhado para o sucesso, insistindo-se em novos procedimentos de normatização e em novas instituições, dentre as quais uma possível Organização Global do Meio Ambiente (Global Environmental Organization - GEO). A necessidade de uma GEO eficaz é tão grande quanto à de uma eficiente Organização Mundial do Comércio (OMC). Os Estados sabem como promover arranjos multilaterais plausíveis, e têm feito isso com freqüência em outras áreas, sobretudo econômicas.

Um segundo caminho muito interessante para o futuro é aplicar medidas que possam ampliar a atuação do Jazz. Hoje em dia o fórum de ação mais animado, com uma enorme avalanche de iniciativas não-escritas e vindas de baixo para cima, tomadas por

${ }^{220}$ FALK, R. Globalização Predatória. Uma crítica. Tradução Rogério Alves. Lisboa: Instituto Piaget, 1999, p. 222.

${ }^{221}$ FALK, R. Globalização Predatória. Uma crítica. Tradução Rogério Alves. Lisboa: Instituto Piaget, 1999, p. 222. 
empresários, ONGs, governos e outros ${ }^{223}$. As ONGs tiveram importantes papéis nas novas iniciativas empresariais. Elas são os verdadeiros organizadores ou condutores do Jazz. Governos locais, universidades e outros organismos também contribuíram.

O terceiro e mais importante dos caminhos para a sustentabilidade é atacar diretamente as causas da degradação ambiental, tais como superpopulação, pobreza e subdesenvolvimento, tecnologia e sinais do mercado. No caso da superpopulação, análises afirmam que se fossem realizadas mais campanhas comprovadamente não-coercitivas, a população mundial poderia permanecer em torno de 8 a 8,5 bilhões ainda neste século. Isso não deverá acontecer sem o necessário apoio ao Plano de Ação do Cairo, promovido pela ONU, que trata do assunto 224 .

Quanto à pobreza e subdesenvolvimento, a pobreza contribui de modo abissal para a deterioração do meio ambiente: os indivíduos menos favorecidos, em geral, têm pouca escolha e dependem substancialmente de recursos ambientais declinantes. No entanto, melhores perspectivas de desenvolvimento também são necessárias, porque o único planeta desejável é aquele em que as aspirações dos povos pobres e das nações menos desenvolvidas, por equidade e justiça, estejam sendo concretizadas. Os pontos de vista dos países em desenvolvimento nas negociações internacionais sobre o meio ambiente são muito bem moldados pela preocupação com os próprios e constrangedores desafios econômicos e sociais e pela desconfiança em relação às intenções e políticas dos países ricos e industrializados.

Para Speth, "o desenvolvimento sustentado e sustentável provê o único contexto no qual há confiança, crédito e esperança suficientes e capazes de fundamentar as difíceis medidas necessárias à concretização dos objetivos ambientais. Eliminar a pobreza em grande escala já não é mais um sonho impossível. Isso pode ser conseguido ainda durante a vida dos jovens de hoje. Entretanto, a exemplo do crescimento populacional, a realização

\footnotetext{
${ }^{222}$ SPETH, J. G. A agenda ambiental global: origens e perspectivas. In: EsTy, C. D.; IvAnOVA, M. H. Governança Ambiental Global. Opções \& Oportunidades. São Paulo: Editora SENAC, 2005, p. 33.

${ }^{223}$ Quatro grandes empresas, incluindo Dupont, Shell, British Petroleum e Alcan, concordaram em reduzir as emissões de dióxido de carbono a 15\% abaixo de seus níveis até por volta de 2010, e a Dupont está trabalhando para reduzi-las em cerca de 65\%; onze empresas de grande porte, dentre ela Dupont, General Motors e IBM, formaram o Green Power Market Development Group, comprometendo-se a desenvolver mercados para 1000 MW (megawatts) de energia renovável ao longo da próxima década; Home Depot, Lowes, Andersen e outras firmas concordaram em vender madeira (desde que disponível) apenas quando oriunda de florestas administradas com vistas à sustentabilidade e certificadas por um grupo independente que use critérios rigorosos. A Uniliver, a maior processadora de peixes do mundo, aceitou as mesmas exigências em relação a seus pescados.

${ }^{224}$ SPETH, J. G. A agenda ambiental global: origens e perspectivas. In: Esty, C. D.; IvANOvA, M. H. Governança Ambiental Global. Opções \& Oportunidades. São Paulo: Editora SENAC, 2005, p. 35.
} 
desses objetivos fica limitada pelos escassos recursos destinados ao desenvolvimento, pelas barreiras comerciais protecionistas e pelos encargos das dívidas"225.

$\mathrm{Na}$ questão da tecnologia, a única forma de diminuir a poluição e o consumo dos recursos e, conjuntamente, de alcançar o esperado crescimento econômico, é realizar uma transformação geral nas tecnologias que atualmente prevalecem nos setores industrial, energético, agrícola e de transporte. Existe, em muitas áreas, tecnologias ambientalmente sofisticadas, já disponíveis ou que em breve o estarão. De 1990 a 1998, quando o uso de petróleo e de gás natural cresceu em todo o planeta a uma taxa anual de $2 \%$, ao contrário do consumo de carvão, que não teve crescimento algum, a geração de energia eólica teve um incremento anual de $22 \%$, e a fotovoltáica, de 16\%; em 2001, o Japão instalou 100 MW de energia fotovoltáica. A transformação do setor energético deve ser encarada como a maior das prioridades ${ }^{226}$.

No quesito sinais do mercado, as prementes mudanças nos padrões de tecnologia e de consumo não se materializarão a menos que ocorra uma revolução paralela nos preços. A mudança mais urgente agora é a fixação de preços ambientalmente respeitáveis. Os preços com todos os custos embutidos são hoje frustrados, porque os governos insistem em conceder subsídios ambientalmente elevados (estimados em US\$ 1,5 trilhão em todo o mundo), a fim de garantir que os preços de mercado absorvam os custos ambientais externalizados. Essas amplas distorções ainda são fatores que definitivamente barram o desenvolvimento da proteção do meio ambiente.

Assim o Jazz ou, no entender de Richard Falk, a "globalização ascendente”, para além de envolver uma multiplicidade de lutas ou causas locais, constitui igualmente um modelo para a promoção da democracia substantiva como contrapeso ao liberalismo ou livre comércio desenfreado. "Fornece uma alternativa, ou uma série de alternativas convergentes, que ainda não foi confirmada como um corpo coerente e coeso de teorias e práticas, permanecendo, porém, como a base comum não articulada da sociedade civil emergente. A democracia substantiva, contrariamente às políticas de oposição que encerram as fronteiras e separam as identidades, procura uma política de reconciliação que mantenha grande parte da abertura ou receptividade e dinamismo associados à

${ }^{225}$ SPETH, J. G. A agenda ambiental global: origens e perspectivas. In: Esty, C. D.; Ivanova, M. H. Governança Ambiental Global. Opções \& Oportunidades. São Paulo: Editora SENAC, 2005, p. 35.

${ }^{226}$ SPETH, J. G. A agenda ambiental global: origens e perspectivas. In: EstY, C. D.; IvANOVA, M. H.Governança Ambiental Global. Opções \& Oportunidades. São Paulo: Editora SENAC, 2005, p. 35. 
globalização descendente, contrabalançando simultaneamente as suas pressões no sentido de privatizar e comercializar a produção de bens públicos"227.

4.4) Aplicação de Princípios e Normas do Direito Internacional do Meio Ambiente pela Empresa

Ao se utilizar o quadro exposto cujo nome dado pelo Conselho Empresarial Mundial para o Desenvolvimento Sustentável é Jazz, pode-se perceber que a atuação conjunta de vários atores do meio ambiente e da sociedade como um todo são vitais para que a proteção ambiental seja alcançada de forma plena. A utilização de modelos cujo empenho único e exclusivo venha dos Estados e organizações internacionais, sem a devida audição e aquiescência de ONGs e empresas, é muitas vezes impossível de se efetivar ${ }^{228}$.

A grande contribuição, conforme se pode perceber, dos tratados e convenções no âmbito do meio ambiente foi delinear normas e, especialmente, princípios que deveriam ser seguidos pelos Estados. Existe uma posição muito crítica no que diz respeito a pouca objetividade e especificidade de normas e preceitos de vários tratados que cuidam do meio ambiente; todavia, há se de entender que a aplicação de diretivas acuradas sobre pontos específicos da matéria induziria, fatalmente, ao não consenso no âmbito das organizações internacionais. Importante salientar que o estudo dos problemas ligados ao meio ambiente, na filosofia de "proteger para preservar", é muito recente. Dessa forma, delimitar os parâmetros comuns de atuação é uma grande vitória e deixa claro até que ponto o consenso tem sido atingido.

Em muitas nações, com o passar dos anos, as idéias, estudos ou proposições foram absorvidas de maneira clara e eficaz. Atualmente, políticas de redução de GEE, por exemplo, fazem parte da cultura de cidades que vão desde São Paulo até São Francisco, na Califórnia. No caso dos Estados Unidos da América, mesmo o país tendo grandes receios na aceitação de uma política internacional mais arrojada para o meio ambiente, seus dirigentes nacionais observam os estados da federação adotarem políticas bem conceituadas e em alguns casos radicais no combate aos danos ambientais.

${ }^{227}$ FALK, R. Globalização Predatória. Uma crítica. Tradução Rogério Alves. Lisboa: Instituto Piaget, 1999 , p. 250. 
Essa absorção de princípios e normas também foi muito bem recebida pela população de vários países. No mais variados locais, seja através de política educacional que disseminou desde a cultura da reciclagem até o consumo de atum cuja pesca seja responsável e não cause a morte de golfinhos -, a cultura do meio ambiente e o uso corriqueiro de princípios do Direito Internacional do Meio Ambiente foram extremamente bem recebidas $^{229}$.

Assim, com a natural demora evolucionária, algo próprio do ser humano, as empresas têm lentamente absorvido um modelo de gestão preocupado com o meio ambiente. Esse modelo tem atuado especialmente nas empresas transnacionais, que possuem grandes responsabilidades perante seus acionistas nos "Estados-sede". Um exemplo bem definido seria a utilização de trabalho infantil para a confecção de bolas de futebol que serão fruto de diversão de crianças dos países desenvolvidos. Esse tipo de incongruência social e econômica tem sido cada vez mais combatida e denunciada pela comunidade internacional.

Dessa forma, ao se retomar os princípios basilares do Direito Internacional do Meio Ambiente, é possível perceber que as empresas em geral têm atuado de forma a aplicar suas diretrizes e normas. Por óbvio que muitas vezes essa atuação também advém de uma certa obrigatoriedade do país onde a empresa se encontra, mas as políticas macroempresariais podem e devem ser formatadas levando-se em conta o arcabouço do Direito Internacional do Meio Ambiente.

Empresas cujo alcance é global compreendem que os tratados, convenções e documentos concertados entre as nações perante órgãos internacionais, por mais que possam ter normas em grande maioria programáticas, são objeto de sistematizações quando de sua aplicação regional ou nacional. Nesse sentido, a aplicação de esforços no intento de minimizar, por exemplo, a emissão de GEE tem se mostrado muitas vezes mais eficaz e imediatamente aplicáveis pelas empresas do que por alguns Estados. Pode-se destacar algumas empresas dos Estados Unidos da América, como General Eletric ${ }^{230}$, Coca-Cola, Wall-Mart, entre outras, como o maior exemplo desse tipo de esforço.

${ }^{228}$ World Business Council for Sustainable Development. Exploring Sustainable Development. Global Scenarios 2000-2005. Genebra: WSBCSD, 1997.

${ }^{229}$ Infeliz daquele que ousar jogar um papel de chocolate ao chão na frente de uma criança brasileira de 10 anos. Certamente terá que ouvir impropérios que não imaginaria ouvir à vinte anos atrás.

${ }^{230}$ Em 2002, os fundos de pensão de várias ordens religiosas, detentores de participação infinitesimal na empresa, requereram a inclusão de proposta de deliberação na ordem do dia da assembléia geral ordinária dos acionistas da General Eletric (GE). A idéia era a de que o conselho de administração ofertasse relatório sobre as emissões de gases do efeito estufa e indicasse as medidas propositivas a serem adotadas para promover a eficiência energética e combater as mudanças climáticas. Os fundos argumentavam que a responsabilidade 
Alguns fundos de pensão que movimentam bilhões de dólares e cuja atuação também é global utilizam-se dos princípios e normas do Direito Internacional do Meio Ambiente para direcionar seus investimentos e desinvestimentos. Neste quesito, a retirada de valores de alguns países que desrespeitavam modelos de gestão sócio-ambiental responsáveis foram motivadores da mudança de legislações inteiras sobre o tema. Nesses casos, os fundos optaram por retornar seus investimentos quando o modelo regulatório se tornou mais claro e os preceitos do meio ambiente passaram a ser respeitados ${ }^{231}$.

\subsection{1) Princípios, normas e lucratividade econômica}

No segundo capítulo dessa dissertação, ao se estudar o fenômeno do comércio e mais recentemente a sua evolução para o modelo empresarial, viu-se que um dos fins precípuos da atividade empresarial é o lucro. A recepção das normas e princípios do Direito Internacional do Meio Ambiente não pode prescindir da análise dos efeitos que podem gerar sobre esse fim. Talvez, nesse sentido, o maior erro do estudioso do Direito seja acreditar que a mudança radical de normas ou a criação de objetivos inatingíveis fará com que o empresário dê continuidade a um ramo que não lhe seja mais interessante, em função, especialmente, da elevada regulação econômica ${ }^{232}$.

Em um momento em que o comércio entre os países atinge seu ápice, em que as relações se estreitam cada vez mais, quando se diz, inclusive, que a planificação do mundo e a aproximação das nações se estagnaram, não havendo mais barreiras para o

ambiental seria favorável aos resultados financeiros da empresa. A GE de início brecou a proposta e determinou sua rejeição formal pelos meios societários rotineiros, mas a reação dos proprietários de ações que compareceram à assembléia geral foi diversa. Nada menos que $23 \%$ deles votaram em oposição à administração e apoiaram a proposta dos fundos. Depois daquela admoestação pública, os executivos decidiram analisar com mais cuidado a recomendação dos novos proprietários capitalistas e determinaram que se estudassem em profundidade as implicações da redução das emissões. Os resultados desses estudos foram surpreendentes e positivos. Se a GE mudasse de curso e convertesse a eficiência energética em missão basilar da empresa, ela não só reforçaria sua reputação no mercado, mas também incrementaria receitas adicionais de pelo menos US\$ 10 bilhões nos cinco anos seguintes. Finalmente, em 2005, a empresa anunciou um grande projeto, abrangendo toda a organização, denominado "ecoimagination", para realizar os objetivos propostos pelos fundos. DAvis, S.; LukomniK, J.; PITT-WATSON, D. Os Novos Capitalistas: a influência dos investidores-cidadãos nas decisões das empresas. Rio de Janeiro: Elsevier, 2008, prefácio.

${ }^{231} \mathrm{O}$ fundo de pensão que atua fortemente dessa forma é o Calpers dos funcionários públicos da Califórnia, Estados Unidos da América.

${ }^{232}$ Segundo Charles Kindleberger, as empresas atuam onde os lucros lhe são mais favoráveis, locais que geram despesas superiores ao custo de produção impedem a permanência no local físico ou a continuação na produção de determinado produto. Klindleberger, C. Manias, Panics, and Crashes: A History of Financial Crises. 5 ed. Hoboken: Wiley, 2005, p. 15. 
desenvolvimento e as ondas da globalização ${ }^{233}$, utilizar barreiras fortemente regulatórias, pode ser um empecilho ao alcance dos objetivos governamentais. Esse tipo de conduta no antigo modelo do "faça ou lhe puno", com as imensas possibilidades de mobilidade tecnológica, tende a afugentar empresas da constituição econômica de alguns países.

Da mesma forma, não se pode olvidar que a análise dos fatores que circundam a produção das empresas, seja através de um planejamento simples, seja por meio de um SGA (Sistema de Gestão Ambiental), pode ter enorme influência no seu desempenho, em razão de poder apontar qual a melhor performance ambiental diante do mercado globalizado $^{234}$. Na perspectiva de bons negócios, o empresariado tende a demonstrar seu interesse pela preservação ambiental ${ }^{235}$.

É sabido que há mais de três séculos o mundo vive numa sociedade de mercado, que tem suas leis próprias e que, muito embora sejam insuficientes, permitem a livre troca de mercadorias e a integração das nações ${ }^{236}$. Como a finalidade da economia de mercado é o lucro, as corporações têm observado os movimentos dos organismos internacionais para tirar dessas normas e princípios o que lhe for mais favorável ${ }^{237}$. É nesse momento que a empresa absorve direta ou indiretamente os princípios do Direito Internacional do Meio Ambiente. Ela incorpora os seus fundamentos mais básicos com as novas necessidades ou anseios que lhe são expostos de maneira mais contundente do que governos, sendo que pode dispor de pessoal e orçamento para a efetivação de seus fins de forma objetiva.

Pode-se perceber que a recepção de normas e princípios do Direito Internacional do Meio Ambiente pelas empresas pode se dar especialmente de duas formas distintas: direta ou indiretamente.

No caso da recepção direta, essa se dá com a participação ou vinculação voluntária do empresariado aos conceitos universalmente aceitos. Por exemplo, não existe obrigatoriedade em que uma empresa tenha como missão empresarial a sustentabilidade, não existem leis em todos os tipos e formas de produção que obriguem uma empresa a ter uma atuação sustentável. Dessa forma, as empresas, individualmente ou por meio de suas

${ }^{233}$ Friedman, T. O Mundo é plano. Uma breve história do Século XXI. Rio de Janeiro: Objetiva, 2005, p. 19.

${ }^{234}$ Business and the Environment: Policy Incentives and Corporate Responses. OECD, 2007, p. 51.

235 Vide o caso das fontes de energias alternativas, onde um estudo divulgado pelo Programa de Meio Ambiente das Nações Unidas (United Nations Environmental Program - UNEP) e que prevê pelo menos 20 milhões de novos empregos no segmento ambiental até 2030, resultará, como se disse, na movimentação de cerca de US\$ 2,74 bilhões em produtos e serviços. UNEP. Green Jobs: Towards Decent Work in a Sustainable, Low-Carbon World. Disponível em: <http://www.unep.org/civil_society/Features/greenjobslaunch.asp>. Acesso em 11 de outubro de 2010.

${ }^{236}$ DERANI, C. Direito Ambiental Econômico. 3 ed. São Paulo: Saraiva, 2008, p. 75.

${ }^{237}$ Derani, C. Direito Ambiental Econômico. 3 ed. São Paulo: Saraiva, 2008, p. 76. 
associações patronais, tendem a perseguir alguns princípios como o do desenvolvimento sustentável, a precaução ou prevenção na produção de determinados bem, a redução da emissão de Gases de Efeito Estufa, entre outras situações.

Em alguns desses casos, pode existir o incentivo pela busca de um "selo verde", ISO 14000 ou até mesmo o enquadramento em índices bursáteis de sustentabilidade ${ }^{238}$. Esse tipo de busca por certificações nacionais e internacionais também é um mote decisivo para que os conselhos de administração de uma empresa optem por um maior cuidado com a questão do meio ambiente de forma voluntária.

No caso da recepção indireta, essa se dá com a participação ou vinculação obrigatória, podendo ainda ser pública ou privada. No caso de recepção indireta com vinculação obrigatória pública, a empresa se vê forçada a adotar métodos de internalização desses princípios e normas do Direito Internacional do Meio Ambiente em função de legislações que determinem a sua regulação. Nesse sentido, pode-se observar a atuação de empresas do setor petroquímico no Brasil, que possuem altas obrigações no sentido de se precaver dos desastres ambientais, devendo, para tanto, na construção de suas plantas industriais, obter licenciamentos ambientais específicos junto ao Ministério do Meio Ambiente.

$\mathrm{Na}$ recepção indireta com vinculação obrigatória privada, pode-se observar o grande trabalho efetuado por bancos e agências financiadoras. Essas, por meio de obrigações específicas, vinculam a concessão de crédito para a construção de uma rodovia, por exemplo, à apresentação de estudo de impacto ambiental adequado, inclusive podendo questionar como o bem a ser produzido ou desenvolvido terá uma atuação especial no desenvolvimento sustentável da região onde estará alocado.

\footnotetext{
238 Já há alguns anos iniciou-se uma tendência mundial dos investidores procurarem empresas socialmente responsáveis, sustentáveis e rentáveis para aplicar seus recursos. Tais aplicações, denominadas "investimentos socialmente responsáveis" ("SRI”), consideram que empresas sustentáveis geram valor para o acionista no longo prazo, pois estão mais preparadas para enfrentar riscos econômicos, sociais e ambientais. Essa demanda veio se fortalecendo ao longo do tempo e hoje é amplamente atendida por vários instrumentos financeiros no mercado internacional. No Brasil, essa tendência já teve início e há expectativa de que ela cresça e se consolide rapidamente. Nesse sentido, a BM\&FBOVESPA, em conjunto com várias instituições ABRAPP, ANBIMA, APIMEC, IBGC, IFC, Instituto ETHOS e Ministério do Meio Ambiente - decidiram unir esforços para criar um índice de ações que seja um referencial para os investimentos socialmente responsáveis, o ISE - Índice de Sustentabilidade Empresarial. Nesse sentido, essas organizações formaram um Conselho Deliberativo presidido pela BM\&FBOVESPA, que é o órgão responsável pelo desenvolvimento do ISE. Posteriormente, o Conselho passou a contar também com o PNUMA (ONU) em sua composição. A Bolsa é responsável pelo cálculo e pela gestão técnica do índice. O ISE tem por objetivo refletir o retorno de uma carteira composta por ações de empresas com reconhecido comprometimento com a responsabilidade social e a sustentabilidade empresarial, e também atuar como promotor das boas práticas no meio empresarial brasileiro. BM\&FBOVESPA. Sustentabilidade. São Paulo, 2010. Disponível em: <http://www.bmfbovespa.com.br/home.aspx?idioma=pt-br>. Acesso em: 13 dez. 2010.
} 
Assim, com esses mecanismos de recepção do Direito Internacional do Meio Ambiente pelas empresas, tem sido possível formatar uma ampla base de apoio para que os danos causados ao meio ambiente sejam mitigados. Ademais, importante salientar em item a parte o caminho da internalização do princípio do desenvolvimento sustentável.

\subsection{2) Desenvolvimento Sustentável e sua efetivação empresarial}

Dentre todos os princípios e normas do Direito Internacional do Meio Ambiente, o princípio do desenvolvimento sustentável foi o que melhor se adequou ao âmbito empresarial. Por ser de fácil assimilação, tal princípio proporciona uma ampla gama de aplicação e adequação aos preceitos do comércio e desenvolvimento. Pode-se comparar inclusive a questão intergeracional do princípio com a necessidade de perpetuação da empresa ou sociedade, uma das finalidades básicas de qualquer instituição econômica.

No capítulo 3 dessa dissertação, observa-se que uma das definições mais aceitas de desenvolvimento sustentável é a de que as atividades econômicas a serem desenvolvidas devem atender às necessidades presentes, sem comprometer a possibilidade de as gerações futuras atenderem às suas próprias necessidades. Nesse ponto, relembre-se o início do presente capítulo onde é citado o caso das empresas Henoquianas: a perpetuação de uma empresa no tempo pressupõe uma atuação correta e estreita que possibilite à geração seguinte de administradores ter ferramentas para o seu desenvolvimento e, consequentemente, dar continuidade à atividade econômica.

Em 2002, durante a Cúpula Mundial sobre Desenvolvimento Sustentável, realizada em Johanesburgo, na África do Sul, a ONU ratificou as Metas de Desenvolvimento do Milênio, que foram instituídas em 2000. Naquela ocasião, apesar do sentimento de frustração quanto aos acordos multilaterais entre governos, a significativa participação do setor empresarial trouxe uma esperança diferenciada para a sociedade global. Ficou demonstrada a possibilidade de geração de valor em sintonia com a promoção do bem estar social e da conservação ambiental.

As decisões de Johanesburgo criaram como conseqüência a necessidade de um novo arranjo entre governos, empresas e sociedade civil em prol do desenvolvimento sustentável. E a liderança empresarial conduz a sua vertente para firmar-se neste contexto. É cada vez maior o número de empresas que incorporam a gestão sustentável na sua 
administração, gerenciando de maneira pró-ativa, ética e transparente seus resultados econômicos, sociais e ambientais.

Um exemplo desse tipo de atuação é o do Conselho Empresarial Brasileiro para o Desenvolvimento Sustentável, que criou em 2004 a Câmara Temática de Gestão Sustentável. Esta Câmara debate e orienta as práticas de sustentabilidade empresarial, por meio de indicadores e relatórios, acompanhando os resultados econômicos, sociais e ambientais. A missão primordial desse grupo é "Debater e intensificar a utilização das práticas de Gestão Sustentável nas empresas brasileiras, potencializando seus efeitos sobre a competitividade e desenvolvimento sustentável nacional".

O grupo tem ainda como objetivos precípuos: “a) Oferecer uma plataforma segura para que as empresas se reúnam para trocar conhecimento, experiência e melhores práticas; para facilitar parceria e empreender iniciativas voltadas para prática da Gestão Sustentável. b) Fornecer informação, direcionamento, produtos e ferramentas que auxiliem as empresas a implementar, medir e comunicar esforços relacionados à ecoeficiência e Gestão Sustentável. c) Representar de maneira pró-ativa a visão das empresas em assuntos relacionados à gestão sustentável, em debates e formulação de políticas públicas com governos e demais stakeholders. d) Disseminar melhores práticas, demonstrando a contribuição das empresas do CEBDS para a qualidade de vida da sociedade brasileira e a conservação do meio ambiente. e) Catalisar as mudanças em direção a um novo modelo de negócios baseado no aumento da competitividade pela promoção do progresso social e gestão racional dos recursos naturais" ${ }^{239}$.

No mesmo sentido de atuação, pode se observar o trabalho pró-ativo da Companhia Braskem. Esta é a maior petroquímica das Américas e terceira maior produtora de polipropileno do mundo, e tem como bases de sua estratégia a competitividade e a autonomia tecnológica, alinhadas com o compromisso de promover o desenvolvimento sustentável. Alguns de seus compromissos voluntários são um exemplo de como as instituições, quando pró-ativas, desenvolvem sintonia interessante com a proteção do meio ambiente.

Um dos compromissos é a iniciativa voluntária criada pela indústria química global por meio do ICCA (sigla em inglês para Conselho Internacional de Associações da Indústria Química). No Brasil, o Responsible Care foi adotado oficialmente pela Associação Brasileira da Indústria Química (Abiquim) em abril de 1992. A partir de 1998,

\footnotetext{
${ }^{239}$ Conselho Empresarial Brasileiro para o Desenvolvimento Sustentável. Gestão Sustentável. São Paulo,
} 2010. Disponível em:< http://www.cebds.org.br/cebds/index.asp>. Acesso em: 13 dez. 2010. 
a adesão ao programa tornou-se obrigatória para todas as empresas associadas da Abiquim. A Atuação Responsável busca aprimorar a gestão ambiental das empresas químicas e da sua cadeia. Entre os itens observados, estão a segurança das unidades fabris, de seus processos e produtos, bem como a preservação da saúde dos trabalhadores e proteção do meio ambiente.

Outro compromisso voluntário é a Declaração Internacional de Produção Mais Limpa. A declaração, assinada por diversas empresas, faz parte do Programa das Nações Unidas para o Meio Ambiente e tem por objetivo disseminar políticas de produção ambientalmente limpa, bem como práticas de produção e consumo mais sustentáveis. Um último exemplo interessante é a Carbon Disclosure Project (CDP), cujo compromisso é coletar e publicar as emissões de gases de efeito estufa de 2.500 organizações, em 60 países.

Esses compromissos voluntários são uma forma bem clara da recepção do Direito Internacional do Meio Ambiente pelas empresas, buscando um aperfeiçoamento de seus trabalhos, com competitividade diferenciada e atualizada às demandas internacionais de proteção ao meio ambiente.

No caso das empresas cujos insumos são derivados do petróleo, alguns dados são alarmantes. É de conhecimento popular que a formação de bacias desse insumo no planeta leva milhões de anos, ou seja, com o esgotamento total das atuais reservas de petróleo, as empresas que não se adaptarem para trabalhar com um novo produto, certamente ficarão para trás na própria perpetuação. Em outras palavras, se a atuação da empresa não for no sentido de preservação do presente sem comprometer o futuro, poderá ter grandes dificuldades de permanecer no tempo.

Dessa forma, observa-se que o desenvolvimento empresarial e o desenvolvimento sustentável possuem linhas mestras que podem se confundir e até mesmo se solidificar para alcançar um ponto ótimo de atuação que preserve os interesses do empresariado e do meio ambiente. Os princípios e normas do Direito Internacional do Meio Ambiente não deixam de ser reverberações dos aspectos da sociedade civil e empresarial.

No caso dos princípios da precaução e prevenção, a idéia primordial por dentro do entendimento estabelecido entre os Estados remonta à mais antiga de todas as noções básicas da sobrevivência humana, qual seja, a de evitar sujeitar-se a situações que demandem uma adversidade superior ao benefício que se alcança. Ao se manter essa linha de noções básicas de sobrevivência, consegue-se inclusive visualizar o nascimento do desenvolvimento sustentável, que seria contornar os malefícios futuros através de 
melhorias no modelo de gestão e com o advento de tecnologias que possibilitem uma atuação forte e confiante no sentido de que os danos serão mitigados de forma substancial $^{240}$.

Assim, uma atuação empresarial que seja responsável, que propugne ações sustentáveis e estabeleça formas de absorver externalidades que sejam negativas ao meio ambiente, está certamente aplicando os princípios e as normas do Direito Internacional do Meio Ambiente, de forma direta ou indireta, deixando um legado positivo para a futura geração de seus acionistas, executivos e funcionários, bem como atenuando os impactos recebidos pelas partes interessadas, externas ao processo produtivo da empresa.

Esse modelo de atuação, no caso das empresas transnacionais, possui um valor mais elevado. A atuação no âmbito mundial induz mudanças e benefícios em vários pontos, especialmente nos países cuja legislação ambiental é menos rígida. O trabalho desenvolvido por empresas multinacionais, que buscam aplicar os princípios e normas do Direito Internacional do Meio Ambiente, traz um alento especial nas comunidades cuja atuação do poder público é limitada pela corrupção e disputa de poderes.

A mudança de comportamento, principalmente daqueles que têm mais poder para tanto, implicaria uma mudança de paradigma. Se algumas organizações se modernizassem ambientalmente e buscassem linhas alternativas na relação com o meio ambiente, certamente os impactos ambientais seriam de outra ordem ${ }^{241}$. Gradativamente a humanidade descortina a falácia da fábula construída pela idéia do progresso e das melhorias sociais, onde o domínio da natureza traz, por si só, todas as benesses ${ }^{242}$. Até porque, no mercado atual, o avanço do comércio precisa estar balanceado com o equilíbrio do meio ambiente, sob pena de danos ambientais malferirem economias como um todo, a exemplo de catástrofes recentes que afetaram por completo mercados emergentes.

As empresas que não têm atuado de forma mais responsável, especialmente nos países em desenvolvimento, estão sofrendo sanções comerciais aos seus produtos por parte da Europa e dos países mais preocupados com o aquecimento global e sua responsabilidade com as presentes e futuras gerações ${ }^{243}$.

\footnotetext{
${ }^{240}$ FALK, R. Globalização Predatória. Uma crítica. Tradução Rogério Alves. Lisboa: Instituto Piaget, 1999, p. 85.

${ }^{241}$ BECK, U. World Risk Society. Cambridge: Polity Press, 1999.

${ }^{242}$ Trennepohl, N. Contornos de uma crise ambiental e científica na sociedade qualificada pelo risco. In: VARela, M. D. (org.). Direito, sociedade e riscos. A sociedade contemporânea vista a partir da idéia de risco. Brasília: UNICEUB, UNITAR, 2006, p. 374.

${ }^{243}$ StiglitZ, J. E. A Globalização. Como dar certo. São Paulo: Companhia das Letras, 2007, p.18.
} 
Assim, esse é mais um motivo para que as empresas atuem de forma plena e eficaz no sentido de alcançar um desenvolvimento que seja sustentável e possua a aplicação das normas e princípios do Direito Internacional do Meio Ambiente como um fim precípuo na sua atuação global e regional. Concomitantemente, deve ser exigida uma política global que pressuponha cooperação entre Estados, iniciativa privada e cidadãos, atuação preventiva e de precaução dos riscos ambientais, com desenvolvimento sustentável, sempre baseado pela informação ambiental e buscando responsabilização dos danos materiais ${ }^{244}$.

A interação das empresas com o meio ambiente tem o grande papel de densificar, firmar, e sustentar a sociedade participativa e democrática, conjugando crescimento econômico e desenvolvimento sustentável ${ }^{245}$. Obviamente, as políticas não são mais suficientes somente em níveis e formas governamentais e estatais, desapegadas do apoio da iniciativa privada, das empresas e do mercado. Talvez a melhor forma de interação com a sociedade, buscando um equilíbrio ambiental, seja através do comércio internacional, de suas peculiares regras, e das subpolíticas que o cercam, nos moldes propostos por Ulrich $\mathrm{Beck}^{246}$.

As perspectivas da globalização, agregando o interesse público ao privado, podem fazer diferença no que diz respeito aos aspectos ambientais. A proteção do meio ambiente deriva da consciência de que os problemas ambientais são transfronteiriços, e extrapolam o limite de um Estado ou de uma comunidade interestatal ${ }^{247}$, devendo, portanto, ser trabalhados de forma conjunta para a sua melhor solução. Um possível colapso ambiental que se avizinha não pode passar despercebido pela sociedade de consumo e pelas instituições públicas e organizações privadas. O viés econômico-financeiro do mercado ambiental que ora se analisa também tangencia temas na ordem dos direitos fundamentais, principalmente pela responsabilidade que passam a ter depois das constituições modernas.

\footnotetext{
${ }^{244}$ Leite, J. R. M.; Ayala, P. de A. Direito Ambiental na sociedade de risco. Rio de Janeiro: Forense Universitária, 2002, p. 256.

${ }^{245}$ Menezes, P. R. B. T. de. O Direito do ambiente na era do risco: perspectivas de mudança sob a ótica emancipatória. Revista de Direito Ambiental, ano 8, n. 32, out.-dez. 2003. São Paulo: Revista dos Tribunais, 2003, p. 134.

${ }^{246}$ BECK, U. World Risk Society. Cambridge: Polity Press, 1999.

${ }^{247}$ Borges, J. S. M. Curso de Direito Comunitário. São Paulo: Saraiva, 2005, p. 517.
} 


\section{CONCLUSÃO}

O Direito é preceito fundamental em uma sociedade. Desde Aristóteles, é por meio do Direito que os seres humanos mantêm acesa a esperança no desenvolvimento da humanidade. É do Direito que a humanidade consegue conter ímpetos indesejáveis, protegendo situações cuja extravagância pode prejudicar terceiros. Hobbes, em o Leviatã, alcança uma máxima bastante peculiar, "o ser humano é mau por natureza". Segundo o filósofo, é da natureza humana buscar a auto-destruição como caminho para satisfazer os mais diversos prazeres e, sendo assim, está justificada a necessidade da vida em sociedade regida por normas eficazes a todos.

Em contrapartida, o cândido Rosseau acredita que na natureza humana não reside nenhuma maldade, a sua convivência em sociedade o transforma em função dos fatos e da história que ali lhe é descortinada. Do mesmo modo, o filósofo acredita que é através do Direito e do Poder dado ao soberano que a harmonia se instala na sociedade e o pacto de sobrevivência se perpetua entre os seres humanos.

Independente do modelo adotado, o ser humano, para poder viver em sociedade, precisa da ação do Direito, limitando direitos e imputando deveres. Primordialmente, o estudo da matéria nada mais é do que analisar formas e mecanismos de manter as relações humanas estáveis.

No ser humano tudo o que não lhe é particularmente próximo, lhe é estranho, diferente. Quando as diferenças são pequenas, acostumar-se com o diferente é algo fácil e absorvível pelo ser humano. No caso das diferenças serem mais substanciais, especialmente quanto à língua falada e escrita, cor da pele, rotinas culturais, entre outras questões, o ser humano denomina o diferente como estranho, e do estranho nasce o estrangeiro.

Dessa forma, aglutinando estranhos que em seu próprio meio eram iguais, foram criadas tribos, patriarcados, matriarcados, vilas, cidades, estados e, no final, nações. E da relação entre os "estranhos" desiguais nasceu a internacionalidade, ou seja, a relação entre nações. Assim, do Direito nasceu a sua vertente estrangeira, o Direito Internacional, cuja matéria é estudar essas relações, estabelecendo freios e contrapesos na citada disputa pela sobrevivência do ser humano. 
O Direito Internacional serviu assim, da melhor forma possível, para o delineamento de fronteiras, acordos, tratados, convenções, resolução de conflitos comerciais, chegando até mesmo a regular as guerras através de códigos de conduta consensualmente aceitos. Ocorre que o ser humano, tendo a sua sobrevivência garantida pelo Direito, nas situações em que deve dividir as necessidades mais próximas e tendo a sua sobrevivência garantida pelo Direito Internacional, nas situações em que deve dividir as necessidades comuns com "estranhos", conjuntamente, passou a consumir produtos e serviços que melhoraram a sua qualidade de vida.

Para além da melhora na qualidade de vida, o ser humano começou a consumir além da capacidade natural de reposição das empresas e comerciantes, gerando uma situação em que a produção deveria aumentar exponencialmente para dar cabo da demanda. O sistema de economia de escala, modelo de produção elevada em série, com baixo custo somado ao desenvolvimento de novas tecnologias, conseguiu reequilibrar a oferta com a demanda.

O meio ambiente, florestas, oceanos, rios, fauna ou a natureza no seu estado mais puro e simples sempre serviu de fascínio e medo para o ser humano. Com a vida em sociedade, os indivíduos foram obrigados a se distanciar do contato com a natureza, com o meio ambiente natural, muitas vezes tomado pelo receio de que "aquilo de que não conheço (florestas, mares), não deve ser bom para mim”. Afastado desse contato, o ser humano retirava da natureza o que era essencial. No entanto, com o passar do tempo e com o desenvolvimento de novos instrumentos e tecnologias, o ser humano passou a enfrentar o meio ambiente com desprezo e desrespeito, destruindo-o para alcançar os seus objetivos (construir estradas, conhecer novas terras, minerar o solo etc.).

O desenvolvimento comercial ajudou nesse vilipêndio acelerado do meio ambiente. As práticas responsáveis de produção e extração de bens do meio ambiente só passaram a ser utilizadas após a ocorrência de catástrofes que atingiram o ser humano. Essas catástrofes precisaram ser de grande vulto, atrapalhando o dia a dia do ser humano, ameaçando a sua sobrevivência, para que algumas medidas fossem tomadas, inicialmente no âmbito doméstico das nações.

Todavia, como alguns dos danos perpassaram as fronteiras dos Estados, foi necessário regular mais uma vez a ação dos seres humanos para que a sobrevivência fosse mantida; o fato dos danos ambientais não obedecerem as fronteiras foi o grande problema. Nesse caso, surge o Direito Internacional do Meio Ambiente, cujo objeto é regular a sobrevivência entre nações no que diz respeito à proteção ambiental. 
O Direito Internacional do Meio Ambiente conseguiu alguns bons progressos de forma consensual: princípios foram criados, vários tratados específicos firmados, situações revertidas, como no caso dos CFCs. Porém, o problema do consumo exagerado e da desigualdade entre as nações não foi superado. Alguns países, para poderem crescer a exitosos $10 \%$ ao ano, literalmente "moveram montanhas"; outros, só foram criar Ministérios do Meio Ambiente no século $\mathrm{XXI}^{248}$; muitos permaneceram na posição de "mover-se a reboque" aguardando o que seu vizinho iria fazer.

Essa situação criou vários impasses, que em sua grande maioria tiveram a chama acesa da esperança de uma solução por meio de Organizações Não-Governamentais. Essas não deixaram de serem grupos de seres humanos que buscaram a sobrevivência de toda a humanidade disputando poder com Estados, empresas e outros organismos. Muitas vezes através da desobediência civil e outras por meio da violência, perdendo inclusive a razão em várias dessas situações. No entanto, o ser humano tem observado que o desenrolar desses estudos e atitudes não tem sido suficiente sem a importante atuação dos grupos que são, em sua grande maioria, os responsáveis pelos níveis alarmantes de danos ao meio ambiente, as empresas.

A presente dissertação tem, em sua fundação, como pano de fundo o estudo da sobrevivência humana sob a ótica do Direito Internacional do Meio Ambiente. Esse estudo, conforme indicado anteriormente, tem o condão de demonstrar quais são as situações em que uma atuação empresarial baseada em princípios e normas da citada matéria é capaz de reverter o crescente perigo ao meio ambiente e, consequentemente, ao ser humano.

Tentou-se demonstrar, também, que a recepção do Direito Internacional do Meio Ambiente pode se dar de formas distintas, seja pela recepção voluntária de normas e princípios ou pela recepção obrigatória pública ou privada, recordando que a ação motivadora da empresa é sempre no sentido de se destacar para poder desenvolver melhor seus trabalhos e aumentar a sua lucratividade.

O enfoque no princípio do desenvolvimento sustentável demonstra que a atuação da empresa não é distinta da idéia de proteção do meio ambiente. A idéia de perpetuar os bens naturais extraindo o que lhe é necessário e mantendo a extração realizável para as próximas gerações, também é o cerne de uma sociedade empresarial, onde os administradores produzem e organizam sua atividade para que ela se perpetue no tempo.

\footnotetext{
${ }^{248}$ A China criou o seu Ministério do Meio Ambiente no ano de 2008. Até então existia uma agência de proteção com status administrativo.
} 
Nesse sentido, tem-se observado a atuação de empresas, especialmente as transnacionais, em um crescendo pró-ativo no sentido de internalizar decisões tomadas em organismos internacionais para se adaptar de antemão à forma como elas chegaram através da legislação de seus Estados reguladores. Esse tipo de atuação tem sido observada muito em função da lucratividade que o "mercado verde" tem se mostrado. Da mesma forma, vários países passaram a atuar de uma maneira mais rigorosa com a entrada de produtos que não obedecessem alguns padrões de conduta para a sua produção, sem contar a crescente pressão dos indivíduos, que deixaram de adquirir produtos e serviços que não estivessem em conformidade com os padrões básicos de responsabilidade sócio-ambiental.

O caminho para se alcançar o objetivo final, que é a proteção do meio ambiente é assaz dificultosa, mas aos poucos está sendo compensada pela atuação conjunta de vários setores da sociedade. A presente dissertação tem o esforço de demonstrar que as empresas também têm agido de uma forma interessante para resguardar suas intenções e corroborar com um meio ambiente mais limpo e sustentável. A demora em se aplicar normas nacionais permite uma maior liberdade de atuação, o que é prejudicial, uma vez que não existe força na lei para impedir alguns danos. No entanto, esse tipo de situação tem sido mitigada com a absorção de princípios e normas do Direito Internacional do Meio Ambiente pela empresa, em uma perspectiva moderna e que tem ajudado a manter para as gerações seguintes o necessário para a sobrevivência humana. 


\section{REFERÊNCIAS BIBLIOGRÁFICAS}

Agência Nacional de Águas. Os Resultados da Conferência - Rio+10. Brasília. 2002. Disponível

em

<http://www.ana.gov.br/AcoesAdministrativas/RelatorioGestao/Rio10/riomaisde z/index.php.39.html>. Acesso em: 03 dez. 2010.

AlmeIdA, Maria Paula Saad Franklin de. Normas jurídicas empresariais. In HeNTZ, L. A.

S. (coord) Obrigações empresariais. Franca: Unesp, 1998.

AlmeIDA, O. Environment and Development. International Conciliation. vol. 585, jan. 1972.

Alves, Alaôr Caffé; PhILIPPI JR., Arlindo (Coord.). Curso interdisciplinar de direito ambiental. São Paulo: Manole, 2005.

Antunes, Paulo de Bessa. Direito Ambiental. Rio de Janeiro: Ed. Lumen Juris, 1998.

Dano Ambiental: Uma abordagem conceitual. Rio de Janeiro: Editora Lumen Juris, 2000.

Aragão, Leandro Santos de; CASTRO, Rodrigo R. Monteiro de (Coord.). Sociedade Anônima - 30 anos da lei 6.404/76. São Paulo: Quartier Latin, 2007.

ASCARELLI, Tullio. Corso di diritto commerciale: introduzione e teoria dell'impresa. $3^{\mathrm{a}}$ ed. Milano: Giuffrè, 1962.

AsQuinI, Alberto. Profili dell'Imprensa. Rivista del Diritto Commerciale, fascs. 1 e 2, 1943.

AulettA, Giuseppe. L'impresa dal Códice di Commercio del 1882 al Codice Civile del 1942. In: 1882-1982 Cento Anni dal Codice di Commercio. Milano: Giuffrè, 1984.

BANTEKAS, Ilias. Natural resource revenue sharing schemes (Trust funds) in international law. Netherlands International Law Review. Cambridge. v.52. n.1. p.31-56. 2005 .

BAPTISTA, Luiz Olavo. Empresa Transnacional e Direito. São Paulo: Revista dos Tribunais, 1987.

BARRETO FILHO, Oscar. Teoria do estabelecimento comercial. 2 ed. São Paulo: Saraiva, 1988.

BECK, Ulrich. World Risk Society. Cambridge: Polity Press, 1999. 
BergeisK, Peter A. G. Van., International trade and the environmental Challenge. Journal of World Trade: law, economics, public policy. Geneva. v.25. n.6. p.105-15. dec. 1991.

BERTOLDI, Marcelo M. Curso avançado de direito comercial. São Paulo: RT, 2001.

BM\&FBOVESPA. Sustentabilidade. São Paulo, 2010. Disponível em: <http://www.bmfbovespa.com.br/home.aspx?idioma=pt-br>. Acesso em: 13 dez. 2010.

BorbA, José Edwaldo Tavares. Direito Societário. $11^{\text {a }}$ Ed. revista, aumentada e atualizada. Rio de Janeiro: Renovar, 2008.

Borges, José Souto Maior. Curso de Direito Comunitário. São Paulo: Saraiva, 2005.

Bowles, Ian A.; Kormos, Cyril F. Environmental reform at the world bank: the role of the U.S. Congress. Virginia Journal of International Law. Charlottesville. v.35. n.4. p.777-839. 1995.

BRANDÃo, Carlos Eduardo Lessa; SANTOS, Homero Luís (Coord.). Guia de Sustentabilidade para as Empresas / Instituto Brasileiro de Governança Corporativa. São Paulo: IBGC, 2007.

BRASIL. Código Civil. Brasília. 2002. Disponível em <http://www.planalto.gov.br/ccivil_03/Leis/2002/L10406.htm>. Acesso em: 26 nov. 2010.

BRASIL. Lei 11.959. Brasília. 2009. Disponível em <http://www.planalto.gov.br/ccivil/_Ato2007-2010/2009/Lei/L11959.htm>.

Acesso em: 26 nov. 2010.

BRASIL. Lei $\mathbf{n}^{\mathbf{0}}$ 4137. Brasília. 1962. Disponível em <http://www3.dataprev.gov.br/SISLEX/paginas/42/1962/4137.htm>. Acesso em: 26 nov. 2010.

BRASIL. Regulamento 737. Rio de Janeiro. 1850. Disponível em <http://www.jusbrasil.com.br/legislacao/103248/decreto-737-50>. Acesso em: 26 nov. 2010.

BROWN WEISS, Edith. "International Equity: A legal framework for a global environmental change". Environmental Change and International Law: New Challenges and Dimensions. New York: United Nations University Press, 1992.

BrunetTi, Antonio. Trattato Del Diritto delle Società. Milão: Dott. A. Giuffrè Ed., 1948. 
BUCKLEY, Ralf. International trade, investment and environmental regulation: an environmental management perspective. Journal of World Trade: law, economics and public policy. Geneva. v.27. n.4. p.101-148. Aug. 1993.

Bulgarelli, Waldirio. Direito Comercial. 14 ed. São Paulo: Atlas, 1999.

Tratado de direito empresarial. 3. ed. São Paulo: Atlas, 1997.

Business and the Environment: Policy Incentives and Corporate Responses. OECD, 2007.

CAldwell, Lynton K. International Environmental Policy: From the Twentieth to the Twenty-First Century. 3 ed. Durham: Duke University Press, 1996.

Carvalho de Mendonça, José Xavier. Tratado de direito comercial brasileiro. Atualizado por Ricardo Negrão. Campinas: Bookseller, 2000, v. 1.

CAUbeT, Christian Guy. A irresistível ascensão do comércio internacional: o meio ambiente fora da lei? Revista de Direito Ambiental. São Paulo. v.6. n.22. p.8199. Abr./Jun. 2001.

CHANG, Seung Wha. GATTing a green trade barrier - eco-labelling and the WTO agreement on technical Barriers to trade. Journal of World Trade: law, economics, public policy. Geneva. v.31. n.1. p. 137-159. Feb. 1997.

COASE, Ronald. The problem of social cost. Journal of law and Economics, Chicago, n. 3, 1960.

CoElHo, Fábio Ulhôa. Curso de direito comercial. São Paulo: Saraiva, vol. 1, 2005.

COLE, Mathew A. Examining the environmental case against free trade. Journal of World Trade: law, economics, public policy. Geneva. v.33. n.5. p. 183-196. Oct. 1999.

Comparato, Fábio Konder. Direito empresarial: estudos e pareceres. São Paulo: Saraiva, 1995.

. Estado, Empresa e Função Social. Revista dos Tribunais, São Paulo, RT 732/38, 1985.

Conference on Ecologically Sustainable Industrial Development. UNIDO. Viena. 1991. Conselho Empresarial Brasileiro para o Desenvolvimento Sustentável. Gestão Sustentável. São Paulo, 2010. Disponível em:< http://www.cebds.org.br/cebds/index.asp>. Acesso em: 13 dez. 2010.

CORRÊA, Leonilda Beatriz Campos Gonçalves Alves. Comércio e meio ambiente: atuação diplomática brasileira em relação ao selo verde. Brasília: FUNAG, 1998.

CorreiA, Antonio Ferrer. Lições de Direito Comercial. Coimbra: Universidade de Coimbra, 1965. 
CRETElla NeTO, José. Empresa transnacional e direito internacional: exame do tema à luz da globalização. Rio de Janeiro: Forense, 2006.

DALLARI, Sueli Gandolfi. Os estados brasileiros e o direito à saúde. 1993. Tese (LivreDocência) - Faculdade de Saúde Pública da Universidade de São Paulo, São Paulo, 1993.

Dalmartello, Arturo. Contratti delle Imprense Commerciali. Padova: Cedam, 1939.

Davis, Stephen; LukomniK, Jon; PITt-Watson, David. Os Novos Capitalistas: a influência dos investidores-cidadãos nas decisões das empresas. Rio de Janeiro: Elsevier, 2008.

DE CUPIS, Adriano. Instituzioni di diritto privato. Milano: Giuffrè, 1978, v. 3.

De La Morandière, Julliot. Droit Commercial. Paris: Dalloz, 1965.

De SouZA, Inglêz. Preleções de Direito Comercial. 5 ed. Rio de Janeiro: Livraria Jacinto, 1935.

Decreto-Lei no 248, de 28 de fevereiro de 1967 - Revogada.

Derani, Cristiane. Direito Ambiental Econômico. São Paulo: Max Limonad, 1997.

DIAS, Jean Carlos. Gestão das Sociedades Anônimas. Curitiba: Juruá, 2001.

DuPuY, Pierre-Marie. Où em est droit international de l'environment à la fin Du siècle?

Reveu Génerale de Droi Public, A. Pedone, Paris, Tome 101, 1997.

Duverger, Maurice. Sociologie de la Politique. Paris: PUF, 1973.

ESPADA, Cesáreo Gutierrez. La Contribuition del Derecho Internacional del Medio Ambiente al Desarrolo del Derecho Internacional Contemporâneo. Anuário de Derecho Internacional. Vol. XIV, 1998.

Esty, C. Daniel; Ivanova, Maria H. Governança Ambiental Global: Opções \& Oportunidades, São Paulo: Editora SENAC, 2005.

FALK, Richard. Globalização Predatória: Uma crítica. Tradução Rogério Alves. Lisboa: Instituto Piaget, 1999.

FINDLEY, Roger W. The future of environmental law. Revista de Direito Ambiental. São Paulo. v.8. n.31. p.9-19. Jul./Set. 2003.

FrANCO, Vera Helena de Mello. Lições de direito comercial. 2 ed. São Paulo: Maltese, 1995.

Friedman, Thomas. O Mundo é plano. Uma breve história do Século XXI. Rio de Janeiro: Objetiva, 2005.

GARRIGUES, Joaquim. Curso de derecho mercantil. 7. ed. Bogotá: Temis, 1987, Tomo I. 
GEER, Martin A. Foreigners in their own land: cultural land and transnational corporations: emergent international rights and wrongs. Virginia Journal of International Law. Charlottesville. v.38. n.3. p. 331-399. 1998.

GOMES, Orlando. Introdução ao direito civil. Atualização e notas de Humberto Theodoro Junior. 15 ed. Rio de Janeiro: Forense, 2000.

GonZalez Aninat, Raimundo. Principios generales del derecho internacional ambiental. Revista de Derecho de la Facultad de Ciencias Juridicas y Sociales de la Universidad de Concepcion. Concepcion. v.60. n.191. p. 105-131. Ene./Jun. 1992.

HAHN, Robert W; RICHARDS, Kenneth R. The internationalization of environmental regulation. Harvard International Law Journal. Cambridge. v.30. n.2. p. 421446. 1989.

HANSEN, Patricia Isela. Transparency, standards of review, and the use of trade measures to protect the global environment. Virginia Journal of International Law. Virginia. v.39. n.4. p. 1017-1068. 1999.

HENTZ, Luiz Antônio Soarez. Direito empresarial: doutrina - jurisprudência. 2. ed. Leme: Editora de Direito, 1998.

INGBER, Léon. Le Pluralisme Juridique dans l'Oeuvre des Philosophes du Droit. In: Le Pluralisme Juridique, Bruxelas: Universidade de Bruxelas, 1972.

InSTITUTO BRASILEIRO DE GOVERnANÇA CORPORATIVA, Guia de orientação para a implementação de portal de governança / Instituto Brasileiro de Governança Corporativa, São Paulo: IBGC, 2008.

Juenemann, João Verner; LAMB, Roberto (Coord.). Guia de Orientação para o Conselho Fiscal / Instituto Brasileiro de Governança Corporativa. $2^{\mathrm{a}}$ Ed. São Paulo: IBGC, 2007.

KENNEDY, David. The Rule of Law at the International Level. In: UN RULE OF LAW UNIT, 2009, Nova Iorque.

Klindleberger, Charles. Manias, Panics, and Crashes: A History of Financial Crises. 5 ed. Hoboken: Wiley, 2005, p. 15.

KISS, Alexander, Sustainable Development and Human Rights. In: TRINDADE, A. A. C. Direitos Humanos, Desenvolvimento Sustentável e Meio Ambiente. São José: IIDH, 1995.

LAVILLE, Élisabeth. A empresa verde. São Paulo: Õte, 2009. 
LeITE, José Rubens Morato; Ayala, Patryck de Araújo. Direito Ambiental na sociedade de risco. Rio de Janeiro: Forense Universitária, 2002.

LIMA, Lucila Fernandes. A moldura regulatória internacional do mecanismo de desenvolvimento limpo do protocolo de Quioto. 2003. 349 p. Dissertação (Mestrado). Faculdade de Direito da Universidade de São Paulo, São Paulo, 2003.

LYSTER, Rosemary. Should we mediate environmental conflict: a justification for negotiated rulesmaking. The Sydney Law Review. Sydney. v.20. n.4. p. 579598. Dec. 1998.

Machado, Paulo Affonso Leme. Direito Ambiental Brasileiro. São Paulo: Malheiros, 2001.

MACHADO, Sylvio Marcondes. Limitação da Responsabilidade de Comerciante Individual. São Paulo: Revista dos Tribunais, 1956.

MAgalhães, José Carlos de. Empresa Multinacional: Descrição Analítica de um Fenômeno Contemporâneo. Revista de Legislação do Trabalho, vol. 39, 1975, pp. 493-509.

MARIANO, Karina Lilia Pasquariello. Relações internacionais e meio ambiente: teoria e história. São Paulo: Centro de Estudos de Cultura Contemporânea, CEDEC 26, 1993.

MARTINS, Fran. Curso de direito comercial. 22. ed. Rio de Janeiro: Forense, 1998.

Matos, Aderbal Meira. Direito, soberania e meio ambiente. Rio de Janeiro: Destaque, 2001 .

MeHTA, Alex; HAWKINS, Keith. Integrated pollution control and its impact: perspectives from industry. Journal of Environmental Law. Oxford. v.10. n.1. p. 61-77. 1998.

Melendez OrTiz, Ricardo. Comercio y medio ambiente en las relaciones comerciales Norte-Sur: GATT, OMC y los acuerdos internacionales sobre medio ambiente. Revista de Ciencias Juridicas. Facultad de Derecho. Universidad de Costa Rica. San José. n.80. p.29-48. 1995.

MENEZES, Paulo Roberto Brasil Teles de. O Direito do ambiente na era do risco: perspectivas de mudança sob a ótica emancipatória. Revista de Direito Ambiental, ano 8, n. 32, out.-dez. 2003. São Paulo: Revista dos Tribunais, 2003.

Messineo, Francesco. Manuale di diritto civile e commerciale. Milano: Giuffrè, 1957, v. 1. 
MiLANI, Carlos. O meio ambiente e a regulação da ordem mundial. Contexto Internacional. Rio de Janeiro. v.20. n.2. p.303-45. Jul./Dez. 1998.

MiLl, John Stuart. Princípios de Economia Política. México: Ed. Fondo de Cultura Económica, 1943.

NAZO, Georgette Nacarato. O direito ambiental no Brasil: evolução histórica e a relevância do direito internacional do meio ambiente, Revista de Direito Administrativo, Rio de Janeiro, n. 224, p. 117-145, abr./jun., 2001.

NEGRÃo, Ricardo. Manual de direito comercial. Campinas: Bookseller, 1999.

NEUMAYER, Eric. Greening the WTO agreements: can the treaty establishing the European Community be of guidance? Journal of World Trade: law, economics, public policy. Geneva. v.35. n.1.p. 145-166. Feb. 2001.

Nosso Futuro Comum. Comissão sobre Meio Ambiente e Desenvolvimento. Rio de Janeiro. 1988.

NUSDEO, Fábio. Curso de economia: introdução ao direito econômico. São Paulo: RT, 1997.

. Direito Econômico Ambiental, in Alves, A. C.; PhillPPI JR., A. Curso interdisciplinar de direito ambiental. São Paulo: Manole, 2005.

Desenvolvimento e Ecologia. São Paulo: Saraiva, 1975.

Organização das Nações Unidas. Agenda 21. 1992. Disponível em <http://www.mma.gov.br>. Acesso em: 16 nov. 2010.

Organização das Nações Unidas. Carta das Nações Unidas. São Francisco. 1945.

Disponível em <http://www.onu-brasil.org.br/doc1.php>. Acesso em: 16 nov. 2010.

Organização das Nações Unidas. Convenção Quadro das Nações Unidas sobre Mudança do Clima. 1992. Disponível em <http://www.onubrasil.org.br/doc_clima.php>. Acesso em: 16 nov. 2010.

Organização das Nações Unidas. Declaração de Estocolmo. 1972. Disponível em <http://www.silex.com.br/leis/normas/estocolmo.htm>. Acesso em: 16 nov. 2010.

Organização das Nações Unidas. Declaração do Rio. 1992. Disponível em <http://www.mma.gov.br>. Acesso em: 16 nov. 2010.

Organização das Nações Unidas. Protocolo de Quioto. 1997. Disponível em <http://www.onu-brasil.org.br/doc_quioto.php>. Acesso em: 16 nov. 2010. 
Organização das Nações Unidas. Resoluções Assembléia Geral. Nova Iorque. 1970. Disponível em <http://www.un.org/Depts/dhl/resguide/r25.htm>. Acesso em: 03 dez. 2010.

Os Resultados da Conferência - Rio+10. Brasília. 2002. Disponível em $<$ http://www.ana.gov.br/AcoesAdministrativas/RelatorioGestao/Rio10/riomaisde z/index.php.39.html>. Acesso em: 03 dez. 2010.

PACHECO, Pedro Mercado. El analisis econômico del derecho - uma reconstrucción teórica. Madrid: Centro de Estúdios Constitucionales, 1994.

PALMER, Geoffrey. New Ways to make international environmental law. The American Journal of International Law. Washington. v.86. n.2. p. 259-83. Apr. 1992.

PALMETER, N. David. Environment and trade - Who will beheard? What law is relevant? Journal of World Trade: law, economics, public policy. Geneva. v.26. n.2. p. 35-41. Apr. 1992.

PETERSMANN, Ernst-Ulrich. International Trade Law and international environmental law. Journal of World Trade: law, economics, public policy. Geneva. v.27. n.1. p. 43-81. feb. 1993.

PFund, Shinya. Perspectives from international economic law on transnational environmental issues. Recueil des Cours. Haye. n. 253. p. 283-432. 1995.

PIGOU, Arthur Cecil. The economics of welfare. 4 ed. Londres: Macmillan and Co., vol. 1, 1932.

Platão. A República. São Paulo: Martin Claret, 2000.

REALE, Miguel. Pluralismo e Liberdade. São Paulo: Saraiva, 1963.

REGE, Vinod. GATT law and environment-related issues affecting the trade of developing countries. Journal of World Trade: law, economics, public policy. Geneva. v.28. n.3. p. 95-169. Jun. 1994.

REQUião, Rubens. Curso de direito comercial. 25 ed. São Paulo: Saraiva, 2003, v. 1.

Rocco, Alfredo. Princípios de Direito Comercial, São Paulo: Saraiva, 1931.

RoCQUE, Eduarda La (Coord.). Guia de orientação para o gerenciamento de riscos corporativos / Instituto Brasileiro de Governança Corporativa. São Paulo: IBGC, 2007.

RUNGE, C. Ford. A global environment organization (GEO) and the world trading system. Journal of World Trade: law, economics, public policy. Geneva. v.35. n.4. p. 399-426. Aug. 2001. 
SAlcedo, Juan Antonio Carrillo. Derecho Internacional em El Mundo em Cambio. Madrid: Tecnos, 1985.

SANTORo Passarelli, F. Saggi di diritto civile. Napóli: Jovene, 1961, v. 2.

SAY, Jean-Baptiste. Tratado de economia política. Tradução de Balthazar Barbosa Filho. São Paulo: Abril Cultural, 1983.

SCHLAGENHOF, Markus. Trade measures based on environmental processes and production methods. Journal of World Trade: law, economics, public policy. Geneva. v.29. n.6. p. 123-155. Dec. 1995.

SILVA, Geraldo Eulálio do Nascimento. Direito ambiental internacional. $2^{\mathrm{a}}$ Ed., Rio de Janeiro: Thex Ed., 2002.

SoARes, Guido Fernando Silva. Curso de Direito Internacional Público. volume I. São Paulo: Atlas, 2002.

. A proteção internacional do meio ambiente. Barueri: Manole, 2003. . Direito Internacional do Meio Ambiente. $3^{a}$ ed., São Paulo: Atlas, 2001.

SouzA, Thelma de Mesquita Garcia e. Governança Corporativa e o Conflito de Interesses nas Sociedades Anônimas. São Paulo: Editora Atlas, 2005.

SPETH, James Gustave. A agenda ambiental global: origens e perspectivas, Governança Ambiental Global. Opções \& Oportunidades. São Paulo: Editora SENAC, 2005.

Stiglitz, Joseph E. A Globalização. Como dar certo. São Paulo: Companhia das Letras, 2007.

Strong, Maurice. Where on Earth Are We Going? Canadá: Alfred A. Knopf, 2000.

Toledo, Paulo F. Campos Salles de (Coord.). Manual prático de recomendações estatutárias / Instituto Brasileiro de Governança Corporativa. São Paulo: IBGC, 2006.

(Coord.). Modelo de regimento interno de conselho de administração / Instituto Brasileiro de Governança Corporativa. São Paulo: IBGC, 2008.

TrennePoHl, Natascha Dorneles. Contornos de uma crise ambiental e científica na sociedade qualificada pelo risco. In: VARELA, M. D. (org.). Direito, sociedade e riscos. A sociedade contemporânea vista a partir da idéia de risco. Brasília: UNICEUB, UNITAR, 2006.

UNEP. Green Jobs: Towards Decent Work in a Sustainable, Low-Carbon World. Disponível em: <http://www.unep.org/civil_society/Features/greenjobslaunch.asp>. Acesso em 11 de outubro de 2010. 
VAN RYN, Jean. Principes de Droit Commercial. Bruxelas: Établissements Émile Bruylant, 1954.

VEDOve, Giampaolo Dalle. Nozioni di diritto d'impresa. Padova: CEDAM, 2000, p. 14; In: FERRARA Júnior, F.; CORSI, F. Gli imprenditori e le societá. 11 ed. Milano: Giuffrè, 1999.

Vigevani, Tullo. Meio ambiente e relações internacionais: a questão dos financiamentos. São Paulo: Instituto de Estudo Avançados, Universidade de São Paulo, Set., 1994.

VON GIERKe, Julius. Derecho Comercial y de la Navegácion. Buenos Aires: Ed. Argentina AS, 1957.

WAELDE, Thomas; KolO, Abba. Environmental regulation, investment protection and regulatory taking in international. International and Comparative Law Quarterly. London. v.50. n.4. p. 811-848. Aug. 2001.

WALD, Arnold. Direito do desenvolvimento. Revista dos Tribunais, São Paulo, RT 383/7, 1967.

WARD, Halina, Trade and environmental in the round - and after. Journal of Environmental Law. Oxford. v.6. n.2. p. 263-295. 1994.

World Business Council for Sustainable Development. Exploring Sustainable Development: Global Scenarios 2000-2005. Genebra: WSBCSD, 1997. 